\title{
COMPENSAÇÃO TAMANHO/DENSIDADE POPULACIONAL DE PERFILHOS EM PASTAGENS DE Cynodon spp.
}

\author{
ANDRÉ FisCHER SBRISSIA
}

Dissertação apresentada à Escola Superior de

Agricultura "Luiz de Queiroz", Universidade de São

Paulo, para obtenção do título de Mestre em Agronomia, Área de Concentração: Ciência Animal e Pastagens.

P I R A C I C A B A

Estado de São Paulo - Brasil

Janeiro - 2000 


\title{
COMPENSAÇÃO TAMANHO/DENSIDADE POPULACIONAL DE PERFILHOS EM PASTAGENS DE Cynodon spp.
}

\author{
ANDRÉ FisChER SbRISSIA
}

ENGENHEIRO AGRÔNOMO

Orientador: Prof. Dr. Sila CARNEIRO DA SILVA

Dissertação apresentada à Escola Superior de Agricultura “Luiz de Queiroz”, Universidade de São Paulo, para obtenção do título de Mestre em Agronomia, Área de Concentração: Ciência Animal e Pastagens.

P I R A C I C A B A

Estado de São Paulo - Brasil

Janeiro - 2000 
Dados Internacionais de Catalogação na Publicação (CIP)

DIVISÃo DE BIBLIOTECA E DOCUMENTAÇÃOO - Campus "Luiz de Queiroz"/ USP

Sbrissia, André Fischer

Compensação tamanho/ densidade populacional de perfilhos em pastagens de Cynodon spp.

André Fischer Sbrissia. - - Piracicaba, 2000.

80 p. : il.

Dissertação (mestrado) - - Escola Superior de Agricultura Luiz de Queiroz, 2000.

Bibliografia.

1. Altura de planta 2. Cinodonte 3. Densidade populacional 4. Gramínea forrageira 5.

Pastagem 6. Perfilhação 7. Variedade I. Título

CDD 633.2

"Permitida a cópia total ou parcial deste documento, desde que citada a fonte - $\mathrm{O}$ autor" 


\title{
DEDICO
}

Aos meus pais

\author{
Luiz Carlos Sbrissia e Ursula Marlei Fischer Sbrissia \\ Aos meus irmãos \\ Gustavo Fischer Sbrissia e Larissa Fischer Sbrissia \\ MINHA GRATIDÃO
}

\section{OFEREÇO}

À minha namorada Elaine Cristina Hack

Ao grande amigo Carlos Augusto Brandão de Carvalho 
"Os teus caminhos posso não entender Senhor, mas sei que tudo é visando o meu crescer, se lutas e tribulações eu tenho que passar, Te peço forças para continuar"

(Jó) 


\section{AGRADECIMENTOS}

À Deus, acima de tudo.

Ao Professor Dr. Sila Carneiro da Silva pela orientação inestimável, paciência e amizade construída ao longo do curso.

Ao Professor Dr. Cory Matthew, da Massey University, Nova Zelândia, pelos valiosos comentários e ensinamentos sobre o assunto.

Ao Professor Dr. Carlos Guilherme Silveira Pedreira pela solicitude e conhecimentos transmitidos.

A todos os professores do Departamento de Produção Animal da ESALQ/USP, especialmente à Prof ${ }^{a}$. Ivanete Susin, responsável pelo setor de Ovinocultura, pela concessão dos animais utilizados no experimento.

Aos colegas de mestrado do GEPF, Carlos Augusto Brandão de Carvalho, Roberta Aparecida Carnevalli, Luis Felipe de Moura Pinto, Jaílson Lara Fagundes e Frederico Alberto de Andrade Rosseto pela ajuda na condução do experimento, pelo incentivo e convivência harmoniosa.

À todos os estagiários do GEPF, que possibilitaram o bom andamento desse trabalho.

Aos colegas do curso de pós-graduação pelo incentivo e amizade.

Aos colegas Robson, Aryeverton, Daltro e José Roberto, com quem dividi moradia durante o curso.

Aos Professores Anibal de Moraes, Beatriz Monte Serrat Prevedello e Adelino Pelissari, da Universidade Federal do Paraná, pelos ensinamentos transmitidos e pela iniciação no universo da pesquisa.

A todos os funcionários do Departamento de Produção Animal pela cooperação e amizade.

À Fundação de Amparo à Pesquisa do Estado de São Paulo (FAPESP), pela concessão da bolsa de estudo. 


\section{SUMÁRIO}

Página

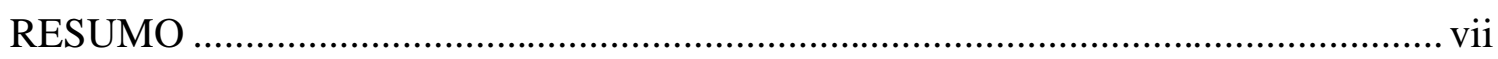

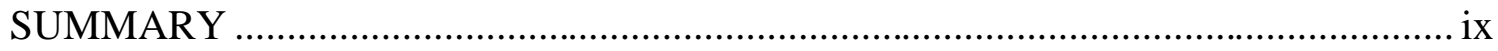

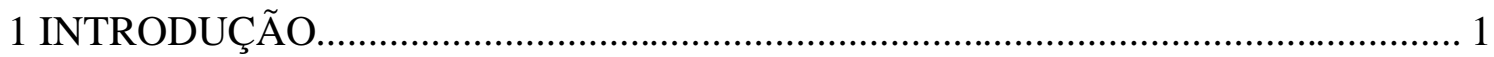

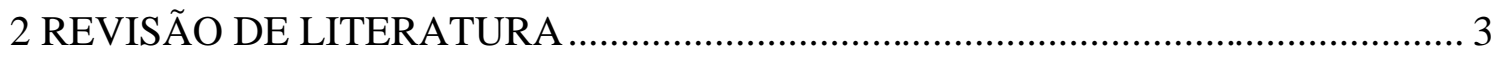

2.1 Processos dinâmicos e equilíbrios em comunidades de plantas forrageiras.................. 3

2.2 Conceituação da lei do auto-desbaste (self thinning rule).......................................... 5

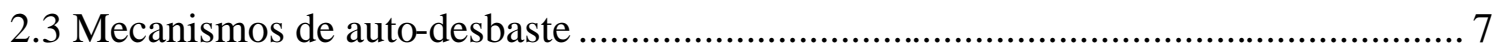

2.4 Compensação tamanho/densidade populacional de perfilhos em pastagens................ 8

2.5 Relação entre índice de área foliar, morfologia do perfilho e o mecanismo de compensação tamanho/densidade populacional........................................................ 11

2.6 Razão área foliar : volume por perfilho (R) e suas implicações ecológicas............... 14

2.7 Aplicações agronômicas.................................................................................. 15

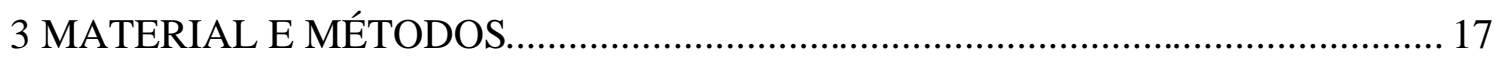

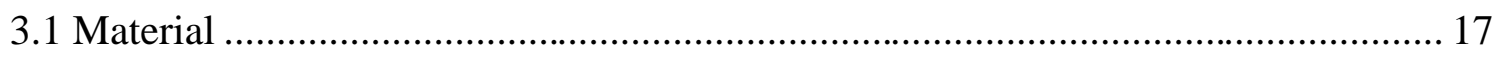

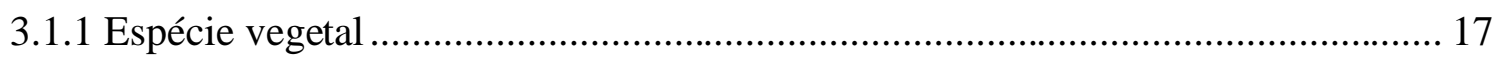

3.1.2 Local do experimento.................................................................................. 17



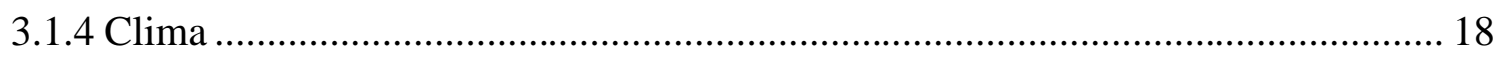

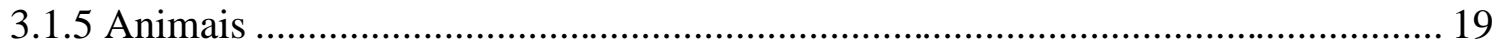



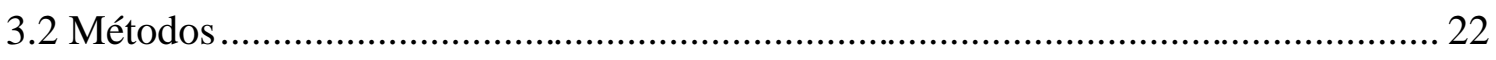

3.2.1 Delineamento experimental e tratamentos ......................................................... 22

3.2.2 Instalação e monitoramento das condições experimentais..................................... 23

3.2.3 Calibração entre a altura comprimida e altura não comprimida............................. 24

3.3 Avaliação dos parâmetros da compensação tamanho/densidade populacional de

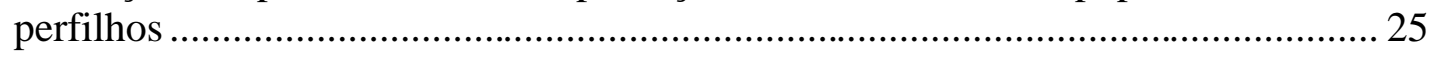

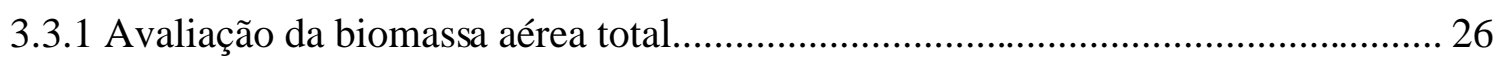

3.3.2 Densidade populacional de perfilhos $\left(\mathrm{n}^{\mathrm{o}}\right.$ de perfilhos $\left./ \mathrm{m}^{2}\right)$................................. 26

3.3.3 Massa de folha, massa "fresca" e massa seca por perfilho........................................ 28 


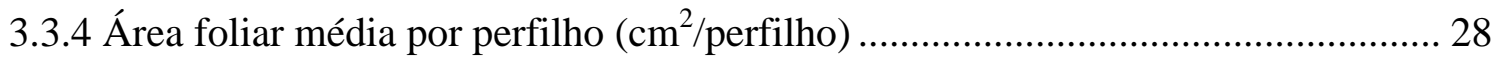

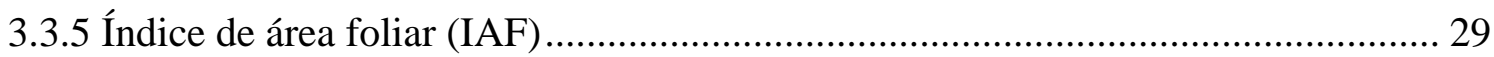

3.3.6 Estimativa do volume médio por perfilho ( $\mathrm{cm}^{3} /$ perfilho) .................................... 30

3.3.7 Cálculo da razão área foliar:volume por perfilho $(\mathrm{R})$............................................ 31

3.5 Regressão Log (densidade populacional de perfilhos) x Log (massa por perfilho). 31

3.6 Cálculo de $\mathrm{C}_{\mathrm{a}}$ e $\mathrm{C}_{\mathrm{r}}$ e da distância entre os pontos obtidos e a reta teórica de

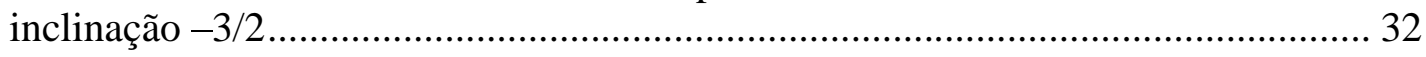

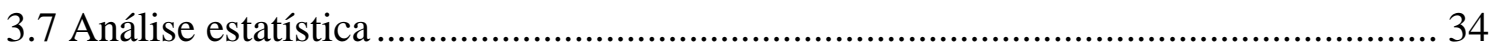

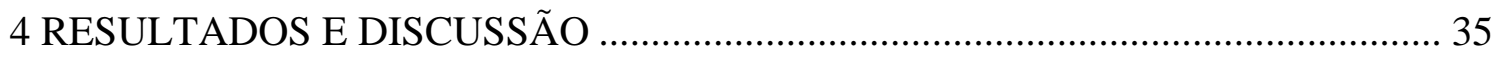

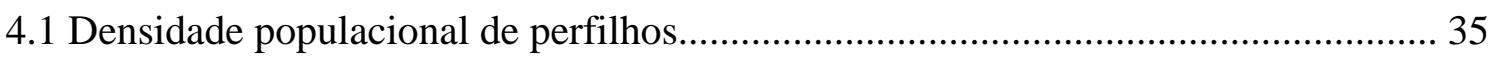

4.2 Massa seca, massa de folhas e volume médio por perfilho ......................................... 39

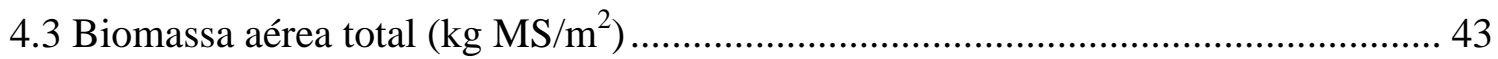

4.4 Área foliar média por perfilho e índice de área foliar do pasto (IAF)....................... 48

4.5 Relação folha:haste e razão área foliar:volume por perfilho (R) …………………... 53

4.6 Relação funcional entre massa e densidade populacional de perfilhos ....................... 61

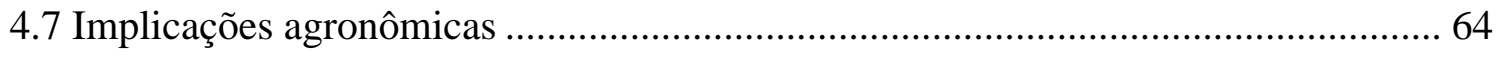

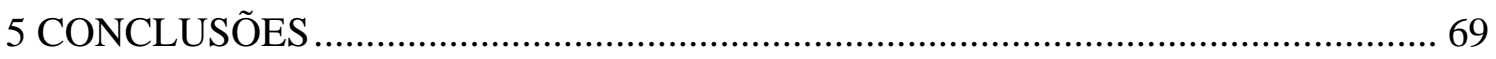

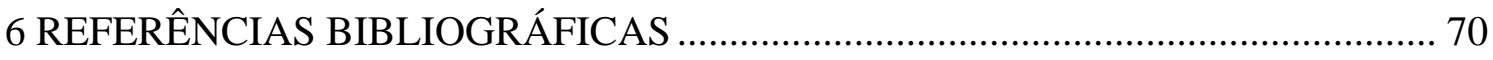




\title{
COMPENSAÇÃO TAMANHO/DENSIDADE POPULACIONAL DE PERFILHOS EM PASTAGENS DE Cynodon spp.
}

\author{
Autor: André Fischer Sbrissia \\ Orientador: Prof. Dr. Sila Carneiro da Silva
}

\section{RESUMO}

O presente experimento foi conduzido no Departamento de Produção Animal da ESALQ/USP, em Piracicaba (SP), entre 15/12/98 e 04/07/99. Os tratamentos foram constituídos pelas combinações entre três cultivares de Cynodon spp. (Tifton-85, Florakirk e Coastcross) e quatro alturas de pasto $(5,10,15$ e $20 \mathrm{~cm})$ mantidas por pastejo de ovinos em regime de lotação contínua e taxa de lotação variável. O delineamento experimental utilizado foi o de blocos completos casualizados em arranjo de parcelas subdivididas com quatro repetições. As parcelas corresponderam aos cultivares e as subparcelas (unidades experimentais) às alturas de pasto. Foram analisadas as seguintes variáveis: biomassa na área total, densidade populacional de perfilhos, massa por perfilho, massa de folha por perfilho e área foliar por perfilho. A partir dessas medições foram realizados cálculos de índice de área foliar do pasto (IAF), volume por perfilho, relação folha:haste por perfilho e relação área foliar:volume por perfilho (R). O mecanismo de compensação tamanho/densidade populacional de perfilhos operou em pastagens de Cynodon spp.. No entanto, as inclinações das retas foram consistentemente maiores que a proposição teórica de $-3 / 2$. Perfilhos individuais de Cynodon spp. apresentaram um padrão de crescimento isométrico e parecem agrupar se em clones para assegurar estratégia competitiva e otimização de IAF. Pastos mantidos a $5 \mathrm{~cm}$ durante o outono apresentaram densidades populacionais reduzidas, indicando um padrão de tolerância ao pastejo dependente da época do ano. Tifton-85 e Coastcross apresentaram uma capacidade de aumento em biomassa que pode ir além da altura de 20 $\mathrm{cm}$, enquanto que para o cultivar Florakirk essa capacidade situourse em torno de $20 \mathrm{~cm}$. 
O estádio reprodutivo das plantas interferiu de forma significativa nos processos de competição intra-específica e dinâmica populacional de perfilhos. 


\title{
TILLER SIZE/POPULATION DENSITY IN GRAZED SWARDS OF \\ Cynodon spp.
}

\author{
Author: André Fischer Sbrissia \\ Advisor: Prof. Dr. Sila Carneiro da Silva
}

\section{SUMMARY}

The experiment was conducted at the Department of Animal Production, ESALQ/USP, Piracicaba (SP), from 15/12/98 until 04/07/99. Treatments were combinations of three Cynodon spp. cultivars (Tifton-85, Florakirk and Coastcross) and four sward surface heights $(\mathrm{SSH})(5,10,15$ and $20 \mathrm{~cm})$ maintained by sheep under continuous stocking and variable stocking rate. A complete randomised block design was used, with treatments arranged in split-plot and replicated four times. Grass cultivars were assigned to plots and SSH to sub-plots. Pastures responses evaluated were: total biomass above ground level, tiller population density, tiller weight, leaf mass and leaf area per tiller. From these measurements calculations of sward leaf area index (LAI), tiller volume, tiller leaf:stem ratio and tiller leaf area:volume ratio (R) were derived. A tiller size/population density mechanism operated in Cynodon spp. However, a slope steeper than the theoretical expectation of $-3 / 2$ was observed. Individual tillers presented an isometric pattern of growth and seemed to demonstrate a clonal integration among tillers in order to enhance competitive ability and optimise LAI. Swards maintained at $5 \mathrm{~cm}$ during autumn presented reduced tiller population densities, indicating a pattern of grazing tolerance dependent of time of the year. Tifton-85 and Coastcross pastures showed a capacity to increase total biomass that could go beyond 20 $\mathrm{cm}$, while Florakirk stabilised around that SSH. Reproductive development of plants interfered with the processes related to intra-specific competition and tiller population dynamics. 


\section{INTRODUÇÃ̃o}

A atividade pecuária, quando baseada no uso de pastagens, depara-se com sucessivos dilemas relacionados a inúmeras combinações de estratégias de manejo que visam assegurar, em última instância, propósitos aparentemente simples; perenidade e produção da planta forrageira associados com a otimização do ganho animal por unidade de área. Apesar dessa aparente simplicidade, os processos envolvidos nas tomadas de decisão comportam-se de maneira oposta. Isto porque os mecanismos que envolvem o acúmulo e utilização de forragem são complexos e extremamente inter-relacionáveis, ou seja, existem compensações que não permitem ganhos otimizados em todos os processos responsáveis pelo acúmulo e utilização da forragem, de forma que o resultado final é sempre um balanço harmônico e específico entre ineficiências e níveis sub-ótimos aceitáveis no sistema de produção.

Além disso, um ecossistema de pastagem deve ser considerado, dentro do aspecto da pesquisa, como um ambiente composto por três universos distintos: solo, planta e animal (todos contidos num ambiente climático). O agente complicador advém do fato de que esses universos são mutuamente relacionados, ou seja, a compreensão das relações causa:efeito deve levar em conta essas interações, o que não permite conclusões generalizadas quando os estudos não consideram o aspecto dinâmico e sistêmico desse ecossistema. Isso significa dizer que pesquisas com pastagens deveriam ser realizadas dentro de um contexto multidisciplinar onde as respostas em cada componente, de cada

universo, fossem analisadas de maneira sistêmica e integrada. É dentro desse enfoque que países como Nova Zelândia, França e Inglaterra, entre outros, pesquisam pastagens, justificando o porquê de serem origem do grande número de citações bibliográficas utilizadas na literatura mundial quando o assunto é plantas forrageiras e pastagens. 
Infelizmente, a pesquisa com pastagens no Brasil, em sua grande maioria, é baseada em parâmetros e variáveis que não permitem um entendimento adequado e efetivo do que ocorre com as plantas forrageiras sob pastejo, uma vez que não consideram, em momento algum, atributos relacionados à planta nem, tampouco, a natureza dinâmica do ecossistema de pastagens. Assim, os resultados obtidos são uma mescla dos ditos "tratamentos" e uma combinação das interações possíveis entre todos os componentes dos sistemas de pastejo, fazendo com que existam inconsistências e antagonismos quando se comparam vários experimentos que avaliaram aspectos semelhantes de uma mesma planta forrageira (Da Silva \& Pedreira, 1997). Um resultado direto disso é o descrédito por parte dos agricultores quanto aos resultados da pesquisa e uma constante busca por plantas mais "adaptadas" e de maior produtividade, fato este que gera um aparente paradoxo na pesquisa, pois as introduções de novas espécies e lançamentos de novos cultivares não são atrelados a estudos que confirmem sua suposta superioridade às espécies e/ou cultivares já existentes. Dentro desse contexto, fica clara a necessidade de trabalhos de pesquisa que reconheçam o caráter dinâmico e altamente complexo de ecossistemas de pastagens. Esse reconhecimento permite que a pesquisa seja planejada de forma a estabelecer guias práticos de manejo desenvolvidos com base na avaliação detalhada de processos básicos que interagem entre si e determinam o caminho, a dinâmica e a natureza das respostas de plantas forrageiras submetidas a desfolha, característica esta que confere consistência aos resultados obtidos e objetividade no planejamento e priorização de pesquisas futuras.

Existe uma série de processos críticos que merecem atenção, dentre eles a demografia do perfilhamento, padrões de interceptação de luz, índice de área foliar (IAF) e compostos orgânicos de reservas, dinâmica do acúmulo de matéria seca, compensação tamanho/densidade populacional de perfilhos, etc.. O presente estudo teve por objetivo avaliar um desses processos, o mecanismo de compensação tamanho/densidade populacional de perfilhos, em pastagens do gênero Cynodon. 


\section{REVISÃO DE LITERATURA}

\subsection{Processos dinâmicos e equilíbrios em comunidades de plantas forrageiras}

Um ambiente de pastagem é caracterizado por uma complexa interação de fatores que lhe confere um aspecto extremamente particular e dinâmico. Dentro de uma comunidade de plantas forrageiras em pastagens existem fatores compensatórios que não permitem ganhos otimizados em todos os processos responsáveis pelo acúmulo e utilização de forragem, razão pela qual a eficiência final é o resultado da interação entre eficiências parciais (crescimento, utilização, conversão) (Hodgson, 1990). Assim, Parsons et al. (1983) mostraram que altas taxas fotossintéticas em azevém perene sob pastejo leniente estiveram associadas com altas taxas respiratórias e maiores perdas de forragem. Por outro lado, os mesmos autores verificaram que os maiores índices de utilização de forragem foram obtidos em pastagens sob regime de desfolha mais intenso. No entanto, isso foi conseguido através de uma redução na taxa de acúmulo líquido. Parsons et al. (1988) compararam efeitos de métodos aparentemente antagônicos de manejo da desfolha (i.e. lotação contínua e lotação rotacionada) sobre alguns parâmetros fisiológicos relacionados com os processos responsáveis pelo acúmulo de forragem e obtiveram resultados similares, indicando a existência de mecanismos compensatórios que tendem a anular possíveis vantagens comparativas de um método sobre outro.

Desse modo, comunidades de plantas forrageiras em pastagens procuram ajustar-se às diferentes condições e intensidades de desfolha através de mecanismos que visem assegurar sua perenidade e eficiência fotossintética. $\mathrm{O}$ principal componente estrutural do pasto sensível a essas adaptações é o IAF (Lemaire \& Chapman, 1996) e uma comunidade de plantas pode otimizá-lo de diversas maneiras. Uma análise dos 
componentes do IAF (eq. 1) mostra que este é composto por três características estruturais distintas do pasto (Matthew et al., 1999): densidade populacional de perfilhos (DPP), número de folhas por perfilho e comprimento da folha.

$$
I A F=P \times F \times A r, \text { onde: }
$$

$\mathrm{P}=$ número de perfilhos por metro quadrado;

$\mathrm{F}=$ número de folhas vivas por perfilho e;

$\mathrm{Ar}=$ área por folha (em metros quadrados).

O número de folhas vivas por perfilho é um valor relativamente constante para uma dada espécie (Davies, 1977; Yang et al., 1998; Carnevalli \& da Silva, 1999). Já a área foliar é determinada basicamente pelo comprimento da folha que, por sua vez, é controlado pela intensidade de desfolha. Dessa forma, a DPP é o componente do IAF que permite a maior flexibilidade de ajuste por parte da planta a diferentes regimes de desfolha, razão pela qual o IAF é otimizado em pastos mantidos baixos através de uma alta densidade populacional de perfilhos pequenos. No entanto, existem limites de plasticidade em perfilhos individuais que, muitas vezes, não permitem que a comunidade de plantas otimize seu IAF. Nessas situações a pastagem pode entrar em colapso e iniciar rapidamente processo de degradação se correções rápidas no manejo da desfolha não forem realizadas (Matthew et al., 1995).

O princípio de compensação tamanho/densidade populacional de perfilhos (CTD) em pastagens tem sido verificado e estudado com intensidade crescente nos últimos anos (Langer, 1963; Bircham \& Hodgson, 1983; Davies, 1988; Chapman \& Lemaire, 1993; Matthew et al., 1995; Sackville Hamilton et al., 1995; Hernández Garay et al., 1999). Há muito tempo sabe-se que plantas crescendo em comunidade possuem um mecanismo de auto-compensação (Puntieri, 1993). No entanto, foi só a partir dos experimentos desenvolvidos por Yoda et al. (1963) que o estudo dos mecanismos envolvidos na compensação tamanho/densidade começou a chamar a atenção da comunidade científica. Isso porque Yoda et al. (1963) derivaram um princípio que seria, ao longo dos anos, verificado para inúmeros tipos de seres vivos, desde algas até 
árvores. Esses mesmos autores denominaram esse mecanismo de "self thinning rule", pois era explicado através de uma simples equação matemática, e chegou a ser considerado por White (1980) como sendo o princípio de maior grau de generalização envolvendo comunidades de plantas.

\subsection{Conceituação da lei do auto-desbaste (self thinning rule)}

A lei do auto-desbaste, proposta por Yoda et al. (1963), descreve uma situação numa população de plantas em crescimento onde ocorre um aumento na massa individual dos indivíduos e uma concomitante redução no número de indivíduos por unidade de área. Esses mesmos autores verificaram que, quando o logaritmo da massa média dos indivíduos era plotado contra o logaritmo da densidade populacional, os pontos formavam um linha reta, com uma inclinação próxima de $-3 / 2$ (coeficiente angular), representada pela equação:

$$
\log w=\log k+\psi \log d,
$$

onde w é a massa média dos indivíduos (em kg ou g), $\mathrm{k}$ é uma constante e $\psi=-3 / 2$.

Outra formulação da lei (matematicamente equivalente) relaciona a biomassa do estande e a densidade populacional de plantas. A biomassa do estande é o resultado da multiplicação entre a densidade populacional (d) e a massa média por perfilho (w):

$$
\begin{aligned}
& \mathbf{B}=\mathbf{d} \times \mathbf{w}, \text { ou: } \\
& \mathbf{w}=\mathbf{B} / \mathbf{d},
\end{aligned}
$$

Substituindo-se a eq. (4) na eq. (2) tem-se:

$$
\log (\mathbf{B} / \mathbf{d})=\log \mathrm{k}+\psi \log \mathbf{d}
$$

$\log B-\log d=\log k+\psi \log d ;$

$\log B=\log k+\psi \log d+\log d ;$ 
Assim;

\section{$\log B=\log k+\Phi \log d$}

onde B é a biomassa total da parte aérea da população (em $\mathrm{g} \mathrm{ou} \mathrm{kg}$ ), $\mathrm{k}$ é uma constante e $\Phi=-1 / 2$. Como pode ser observado através das eq. (2) e (7), os parâmetros $\psi$ e $\Phi$ são relacionados $(\Phi=\psi+1)$. Devido a formulação matemática da eq. (2) e do seu expoente, Yoda et al. (1963) denominaram essa relação de "-3/2 power law of self thinning", que, na ausência de um termo em português, será tratada aqui como lei do auto-desbaste. A partir do trabalho de Yoda et al. (1963) vários estudos suportaram a existência dessa relação; desde trabalhos com plantas daninhas até árvores (Weller, 1985). Yoda et al. (1963) apresentaram 10 conjuntos de dados que comprovaram tal relação. White \& Harper (1970) apresentaram outros cinco e White (1980) apresentou mais 36 exemplos e mencionou outros 80 não publicados.

Apesar da lei ter se tornado amplamente aceita (White \& Harper, 1970; Harper, 1977; White, 1980, 1981, 1985; Westoby, 1984), sua justificativa matemática original foi reconhecida como uma aproximação grosseira (Yoda et al., 1963) e muito simplificada (White, 1981). Alguns autores questionaram a validade da lei (Weller, 1985, 1987, 1989, 1990, 1991; Zeide, 1985, 1987), alegando que nem todas observações acompanhariam a dinâmica de auto-desbaste definida pela inclinação de $-3 / 2$. Lonsdale (1990), após uma análise cuidadosa das descobertas de Weller (1985) e Zeide (1987), concluiu que até então não havia evidências para a existência de uma lei de autodesbaste (-1/2 ou -3/2). Weller (1990) argumentou que a reta de inclinação -3/2 representava estritamente um limite superior das possíveis combinações de produção/densidade para as espécies e a chamou de "linha limítrofe das espécies" (species boundary line), e salientou que num estande denso de plantas a população seguiria uma "linha dinâmica de desbaste" (dynamic thinning line) com o passar do tempo.

A eq. (2) descreve uma reta de inclinação -3/2 num gráfico de $\log$ w:log d (o logaritmo sendo usado para uniformizar as escalas tendo em vista a amplitude numérica 
para os valores de densidade populacional e de massa por perfilho). Sackville Hamilton et al. (1995) argumentaram que, de acordo com a lei, a reta representava uma "linha limite", a qual, por analogia com a "linha limítrofe das espécies" de Weller (1990), poderia ser chamada de "linha limítrofe das populações" (population boundary line). Segundo esse conceito, uma população de plantas de um determinado hábito de crescimento em um dado meio ambiente poderia ocupar qualquer posição abaixo da linha, mas nunca transgredí-la. No limite, as plantas poderiam crescer apenas se outras morressem, num processo conhecido como auto-desbaste (self-thinning). Se as populações alcançassem a linha limite e, desde que as plantas sobreviventes continuassem a crescer mantendo a população sobre a linha limítrofe, e, desde que o limite não mudasse (mudanças na intensidade luminosa, por exemplo), a população seguiria uma reta de inclinação $-3 / 2$, com aumento na biomassa e decréscimo na densidade populacional de perfilhos (Sackville Hamilton et al., 1995).

\subsection{Mecanismos de auto-desbaste}

É geralmente aceito que a mortalidade num estande que está passando por autodesbaste ocorre principalmente como consequência da competição por luz, ou seja, são as plantas pequenas que morrem, e a morte dessas plantas acontece quando elas não mais mantém suas folhas alto o suficiente no relvado para manter um balanço positivo de carbono (Westoby, 1984). Evidências contrárias de que os nutrientes também mudariam a posição da reta (Westoby, 1984; Morris \& Myerscough, 1991) são vagas. Por exemplo, no experimento de Morris \& Myerscough (1991), o desbaste de estandes a partir de alta e baixa densidade populacional inicial sob um mesmo nível baixo de nutrientes não revelou convergência para a mesma linha, sugerindo que eles não estavam se auto-desbastando.

A evidência mais direta de que é a competição por luz, mais que aquela por nutrientes, que causa a mortalidade de plantas em estandes é que o aumento na intensidade luminosa mudaria a linha limite "para cima", reduzindo a mortalidade (Yoda 
et al., 1963; White \& Harper 1970; Hutchings \& Budd, 1981 ab; Westoby \& Howell, 1981, 1982), enquanto que aumentando-se os níveis de nutrientes aumentaria-se a taxa de progressão sobre a reta, sem mudar a posição dela (Yoda et al., 1963; White \& Harper, 1970). A implicação disso é que um aumento no suprimento de nutrientes aumentaria a taxa de mortalidade pelo aumento na taxa de crescimento, com consequente aumento na competição pelo fator luz (Sackville Hamilton et al., 1995). Além disso, a redução no nível de luminosidade diminui o intercepto da linha de autodesbaste (White 1981, Hutchings \& Budd, 1981ab, Westoby \& Howell, 1981), possivelmente devido à diminuição na quantidade de matéria seca por unidade de espaço ocupado (Lonsdale \& Watkinson, 1982, 1983).

A evidência contraditória do efeito de nutrientes sobre o mecanismo de autodesbaste é por ela mesma sugestiva de seu efeito indireto, ou seja, se os nutrientes realmente mudassem a inclinação da reta, isso poderia se dar através de seu efeito sobre a taxa fotossintética e, consequentemente, sobre o ponto de compensação luminosa e o valor teto de índice de área foliar (IAF) (Sackville Hamilton et al., 1995).

\subsection{Compensação tamanho/densidade populacional de perfilhos em pastagens}

Em pastagens de gramíneas a unidade primária de crescimento é o perfilho, sendo que uma pastagem pode ser considerada como uma população de perfilhos (Mitchell \& Glenday, 1958; Korte, 1986; Colvill \& Marshall, 1984). Assim, aumentos de produção de forragem podem ser atribuídos a aumentos em densidade populacional, massa por perfilho ou uma combinação de ambos (Nelson \& Zarrough, 1981; Bircham \& Hodgson, 1983; Grant et al., 1983; Volenec \& Nelson, 1983). Sob baixas densidades populacionais de perfilhos tem-se interpretado que a formação de perfilhos é mais determinante da produção que a massa por perfilho (Nelson \& Zarrough, 1981; Hernández Garay et al., 1997). Quando a população de perfilhos do pasto é alta, ou a pastagem se torna reprodutiva, a massa por perfilho torna-se mais importante (Volenec \& Nelson, 1983). 
A densidade populacional de perfilhos é frequentemente avaliada e utilizada como um indicador do vigor e/ou persistência em pastagens, ou como um componente de resposta como, por exemplo, à aplicação de fertilizantes nitrogenados (e.g. Davies, 1971; Curll et al., 1985; Neuteboom et al., 1993). No entanto, sabe-se também que perfilhos em pastagens estão sujeitos ao mecanismo de compensação tamanho/densidade, havendo uma densidade populacional reduzida de perfilhos grandes sob regimes de desfolha mais lenientes ou menos intensos (Bircham \& Hodgson, 1983; Grant et al., 1983; Matthew, 1992). Dessa forma, o aumento ou o decréscimo em densidade populacional de perfilhos é um indicador ambíguo do vigor do pasto e pode, em alguns casos, refletir meramente a compensação tamanho/densidade em resposta a uma mudança na intensidade de desfolha (Matthew et al., 1995). No caso de pastagens, a lei de auto-desbaste descreve, portanto, a relação entre tamanho médio e densidade populacional média de perfilhos numa população de plantas em crescimento e, por isso, sujeita a uma mortalidade dependente da densidade, ou seja, a um mecanismo de compensação entre tamanho e densidade populacional de perfilhos (Matthew et al., 1995).

Em relvados que não sofreram desfolha, a compensação tamanho/densidade foi observada segundo uma reta de inclinação $-3 / 2$, exceto em condições de baixo nível de luminosidade (Kays \& Harper, 1974; Lonsdale \& Watkinson, 1982). Tem-se assumido, genericamente, que pastos sob desfolha também seguem a mesma lei (Bircham \& Hodgson, 1983; Lambert et al., 1986; Davies, 1988; Xia, 1991). No entanto, análise visual dos dados de Davies (1988) sugeriu uma sistemática falta de ajuste à inclinação teórica de -3/2 (Sackville Hamilton et al., 1995), com uma inclinação verdadeira maior que -3/2. Matthew (1992) também observou inclinação maior que $-3 / 2 \mathrm{em}$ pastos de azevém perene (Lolium perenne L.) sob desfolha. Matthew et al. (1995) argumentaram que em pastos sob desfolha um diagrama multifásico de compensação tamanho/densidade seria esperado, isto é, haveria 4 fases, cada uma delas representando diferentes situações do estado da pastagem (Figura 1). Segundo esses autores, as quatro fases seriam: (1) baixa massa de forragem (tamanho pequeno de perfilhos) - Nível de energia no perfilho seria baixo e o pasto teria aparecimento de novos perfilhos 
insuficiente para atingir a linha $-3 / 2$ de auto-desbaste (self thinning) através do aumento no número de perfilhos; (2) Área foliar variável (fase de rebrota) - auto-desbaste a uma inclinação de -5/2; (3) área foliar constante - auto-desbaste a uma inclinação de -3/2; e (4) Massa de forragem constante (situação hipotética) - auto-desbaste a uma inclinação de -1 . O ponto de transição $\left(\mathrm{d}_{\mathrm{i}}\right)$ entre as fases (2) e (3) seria considerado como um indicador da altura de pasto ideal para uma determinada espécie ou cultivar, uma vez que se a rebrota prosseguisse além desse ponto a perda de perfilhos passaria a ser maior para um aumento correspondente em massa de forragem ( $\mathrm{kg}$ de matéria seca/ha).

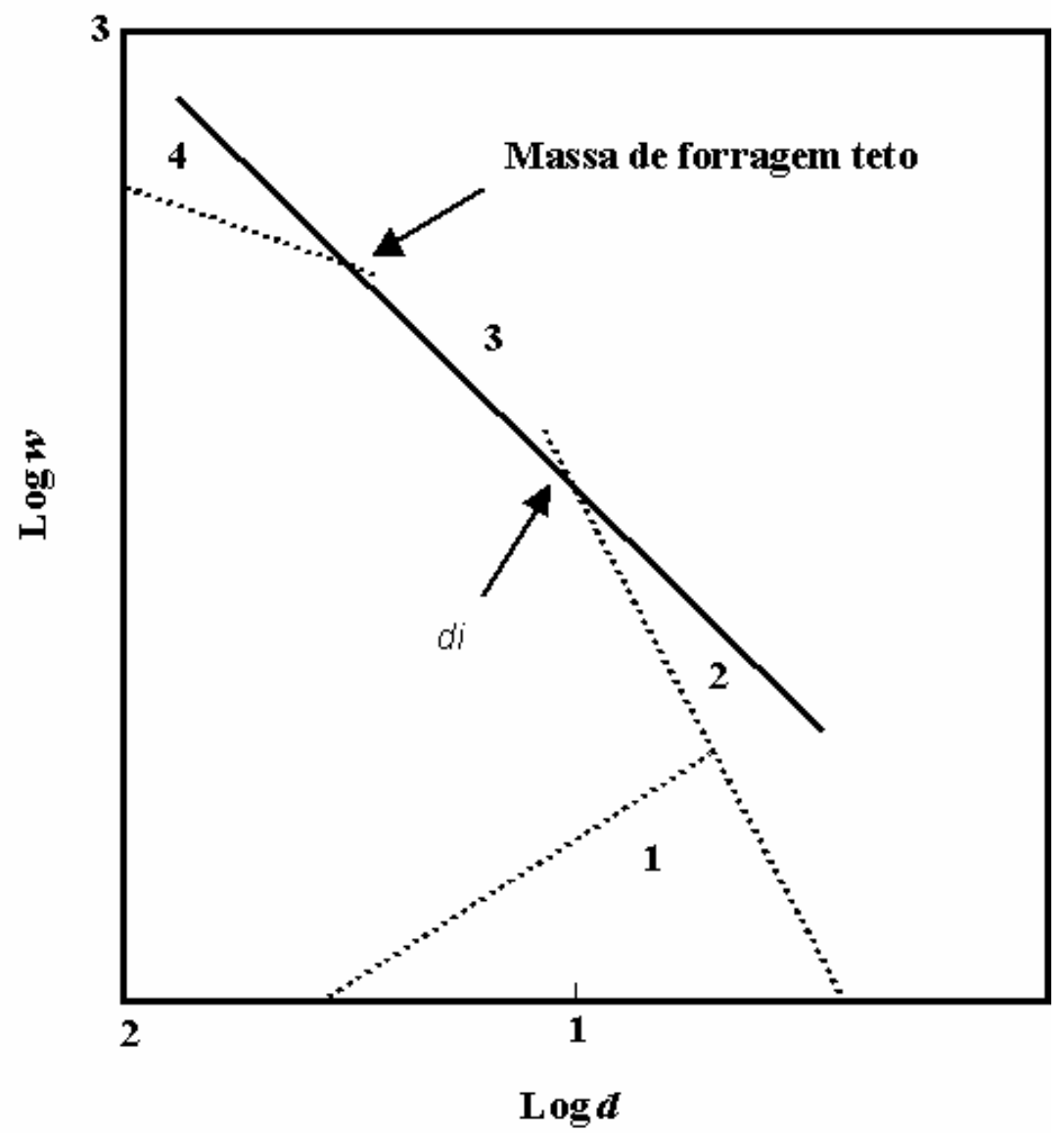

Figura 1 - Ilustração esquemática da compensação multifásica tamanho/densidade populacional de perfilhos em pastos sob desfolha. (1). Relações tamanho/densidade populacional de perfilhos não definidas. (2). Autocompensação com área foliar variável e inclinação log w:log d próxima de -5/2. (3). Auto compensação com área foliar constante e inclinação log w: $\log$ d próxima de $-3 / 2$. Adaptado de Matthew et al. (1995). 


\subsection{Relação entre índice de área foliar, morfologia do perfilho e o mecanismo de compensação tamanho/densidade populacional}

Apesar das controvérsias a respeito da existência da lei do auto-desbaste, Sackville Hamilton et al. (1995) mostraram que uma reta de inclinação -3/2 seria uma perspectiva teórica quando o índice de área foliar e a razão entre área foliar e o tamanho da planta permanecessem constantes. Considerando que a área foliar varia durante a rebrota ou em resposta à intensidade de desfolha (Bircham \& Hodgson, 1983; Matthew et al., 1995; Fagundes, 1999), é natural que a compensação tamanho/densidade em relvados sob desfolha assuma inclinações diferentes de $-3 / 2$.

Além do IAF, Sackville Hamilton et al. (1995) mostraram também que o ajuste de uma reta de inclinação $-3 / 2$ está relacionado com variações morfogenéticas dos perfilhos para diferentes alturas de pasto. Dessa forma, esses autores formularam uma razão, denominada $\mathrm{R}$, que relaciona a área foliar média por perfilho com o seu volume. Segundo Hernández Garay et al. (1999), avaliações da relação folha:haste por perfilho seriam impróprias para efeito de cálculos da compensação tamanho/densidade populacional de perfilhos uma vez que folha e haste são componentes da planta que possuem dimensões diferentes e a relação folha:haste por perfilho não leva essas diferenças em consideração, já que a relação é baseada numa mesma unidade (kg). Dessa forma, aumentos em altura do pasto quase sempre conduzem a uma redução concomitante na relação folha:haste por perfilho pelo fato de que para suportar o peso de um órgão (no caso as folhas) o diâmetro das estruturas de suporte (no caso as hastes) altera-se em proporção à força requerida para suportá-lo, e não isometricamente com o seu peso (McMahon, 1973; McMahon \& Kronauer, 1976; Niklas, 1994). Dessa maneira, a fim de que a lei do auto-desbaste possa relacionar-se com a compensação tamanho/densidade populacional de perfilhos existente numa série de pastagens mantidas em diferentes alturas, é necessário que se corrija para variações em IAF, como uma função da taxa de remoção de forragem (pressão ou altura de pastejo), e para variações em $\mathrm{R}$, devido a variações morfogenéticas dos perfilhos conforme estes se ajustam às diferentes alturas de pasto (Matthew et al., 1995). 
As correções para IAF e R foram propostas por Matthew et al. (1995) e denominadas $\mathrm{C}_{\mathrm{a}}$ e $\mathrm{C}_{\mathrm{r}}$, respectivamente. Ambas definem uma correção "C" (Figura 2), onde $\mathrm{C}=\mathrm{C}_{\mathrm{a}}+\mathrm{C}_{\mathrm{r}}$, que representa uma mudança vertical hipotética na reta $-3 / 2$. Para explicar $\mathrm{C}_{\mathrm{a}}$, considera-se que aumentos no tamanho de perfilhos ocorrem com aumentos na altura do pasto. Dessa forma, o IAF do pasto também aumenta. A variação na inclinação da linha de compensação tamanho/densidade populacional de perfilhos em relação ao valor teórico de $-3 / 2$ pode ser definida como o deslocamento da linha de um IAF constante (-3/2) para uma outra linha de IAF também constante só que com um intercepto mais alto. Isso geraria uma nova linha com inclinação maior que $-3 / 2$ e a correção seria expressa como o aumento teórico em densidade populacional de perfilhos necessário para alcançar a nova linha de IAF constante ou como uma mudança no intercepto da linha teórica de IAF constante (Matthew et al. 1995) (Figura 2). Já $\mathrm{C}_{\mathrm{r}}$ poderia ser explicado como variações que ocorrem na forma do perfilho conforme ocorrem variações na densidade populacional para as diferentes alturas de pasto. Assim, se uma grande modificação na forma do perfilho não for acompanhada por um incremento compatível em IAF, a correção $C_{r}$ prediria uma inclinação maior que -3/2, já que a diferença $C$ (Figura 2) é o resultado da soma de $C_{a}+C_{r}$ e este último assumiria normalmente um valor negativo (Matthew et al., 1995). Por outro lado, se a soma de $\mathrm{C}_{\mathrm{a}}$ e $C_{r}$ for igual a zero a inclinação da reta seria $-3 / 2$, uma vez que a inclinação, corrigida para variações em IAF e morfologia do perfilho, seria estimada pela seguinte fórmula (Matthew et al., 1995):

$$
\text { Inclinação }=-\left(\mathrm{C}_{\mathrm{a}}+\mathrm{C}_{\mathrm{r}}+3 / 2\right)
$$

Dados com azevém perene mostraram que $\mathrm{C}_{\mathrm{a}}$ possui um valor próximo de 2,0 e $\mathrm{C}_{\mathrm{r}}$ próximo de $-0,2$, indicando que o valor $\mathrm{R}$, por aumentar em pastos mais altos, reduziu a inclinação da reta predita por $\mathrm{C}_{\mathrm{a}}$ (Matthew et al., 1999). Estas duas correções praticamente explicaram a discrepância entre a inclinação teórica de $-3 / 2$ e o valor realmente observado para os dados coletados e analisados. Dessa forma Matthew et al. (1995) observaram inclinações para azevém próximas de $-5 / 2$, sendo que algumas 
observações anteriores a essa (Davies, 1988) também suportaram as conclusões daqueles autores.

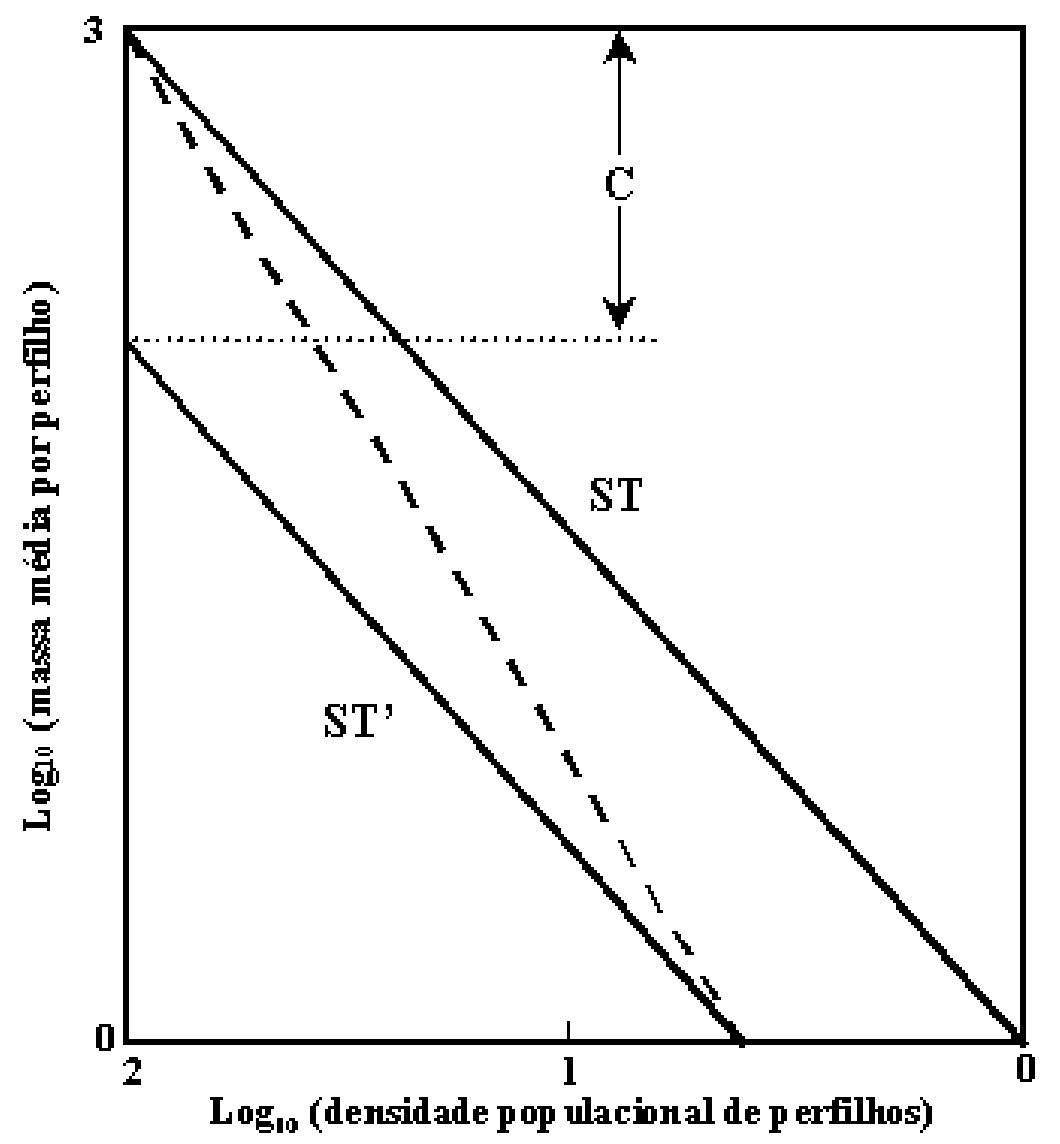

Figura 2 - Ilustração conceitual de uma reta de inclinação mais negativa que -3/2, como resultado das variações em IAF ou na relação área foliar:volume (R) no pasto. Eixos x e y correspondem à densidade populacional de perfilhos e massa por perfilho, respectivamente. ST, reta de inclinação $-3 / 2$, representando o máximo IAF suportado pelo ambiente; ST', representa uma hipotética mudança na reta -3/2 caracterizada pela distância vertical C; (-----) mostra a inclinação aparente da reta de compensação.

Num outro experimento, Hernández Garay et al. (1999) verificaram inclinação para azevém de $-2,56$, sendo a inclinação predita pelas correções $C_{a}$ e $C_{r}$ de $-2,68$, 
confirmando que as correções foram capazes de explicar, para plantas temperadas, as diferenças entre as inclinações observadas e a expectativa teórica de $-3 / 2(-1,5)$.

\subsection{Razão área foliar : volume por perfilho $(\mathbf{R})$ e suas implicações ecológicas}

Experimentos com azevém perene mostraram que a razão $\mathrm{R}$ assumiu um valor de aproximadamente 50 (Matthew et al., 1995; Hernández Garay et al., 1999). Além disso, no trabalho de Hernández Garay et al. (1999) seu valor aumentou conforme eram aumentadas as alturas do pasto. Isso significa que o comprimento das folhas (determinante da área foliar no perfilho) aumentou proporcionalmente mais que o comprimento da pseudo-haste (determinante do volume do perfilho) à medida que o pasto aumentava em altura. Por outro lado, a relação folha:haste por perfilho, não corrigida para as diferenças em dimensão entre folha e haste, diminuiu. Isso aconteceu porque a relação entre área e volume de um objeto, tal como a proporção entre folha e haste de uma planta, mudam conforme o tamanho da unidade em estudo. No caso de pastagens, perfilhos maiores, em pastos altos, reduziriam sua relação área:volume. $\mathrm{O}$ mesmo aconteceria com a relação folha:haste por perfilho (expressa com base em massa). Por outro lado, em pastos mais altos ocorre um aumento do comprimento da folha, o que aumentaria o valor das relações. Dessa maneira, folha e haste operam em direções opostas, de tal maneira que o desenvolvimento de um pode compensar parcial e, às vezes completamente, o desenvolvimento do outro (Hernández Garay et al., 1999). Assim, Hernández Garay et al. (1999) argumentaram que, para efeito de cálculos de compensação tamanho/densidade populacional de perfilhos, medições da relação folha:haste por perfilho seriam inapropriadas e se fazia necessário, portanto, uma medição que fosse independente do tamanho do perfilho (R). Em outro contexto outros autores (e.g. Louie et al., 1998) mostraram algumas vantagens de se introduzir parâmetros adimensionais para descrever sistemas biológicos. 
Segundo Matthew ${ }^{1}$, Dactylis glomerata (L.) é capaz de desenvolver um valor de R muito maior que Lolium perenne (L.) explicando, provavelmente, a dominância da primeira espécie sobre a segunda quando as duas estiveram sujeitas à desfolhas lenientes. Dessa maneira, Matthew et al. (1995) argumentaram que variações interespecíficas em $\mathrm{R}$ poderiam ter implicações na habilidade competitiva das diferentes espécies para um dado meio ambiente. Segundo esses mesmos autores, uma maior proporção de área foliar em relação ao volume (maior R) poderia conferir às plantas uma maior taxa de crescimento, um dos mecanismos caracterizadores de tolerância ao pastejo (Briske, 1996), enquanto que um valor de $\mathrm{R}$ menor poderia estar associado com resistência a estresses. Matthew et al. (1999) argumentaram que uma melhor compreensão dessas variações inter-específicas em R poderia ter implicações ecológicas importantes.

\subsection{Aplicações agronômicas}

A compreensão teórica dos desvios entre dados de campo e a reta $-3 / 2$ tem algumas implicações importantes. Matthew et al. (1995) sugeriram que a distância de qualquer ponto relacionando massa e densidade populacional de perfilhos para a linha teórica de inclinação $-3 / 2$ poderia ter valor como um índice de produtividade do pasto. Isto porque a reta $-3 / 2$, como mostrado por Sackville Hamilton et al. (1995), define uma situação onde o IAF passa a ser constante. Dessa maneira, quanto maior a distância entre os pontos observados e a reta $-3 / 2$, maior o IAF do pasto e, consequentemente, maior sua capacidade de acúmulo de matéria seca. Esta hipótese foi confirmada com experimentos em micro relvados (Hernández Garay et al., 1999) e em situações de campo (Hernández Garay, 1996; Bahmani et al., 1998) para gramíneas temperadas, particularmente azevém perene.

Outra implicação é que, num determinado ambiente, quando o pasto atinge o seu valor máximo de IAF, a nova linha de compensação tamanho/densidade

\footnotetext{
${ }^{1}$ Matthew, C. (Massey University, Nova Zelândia). Comunicação pessoal, 1999.
} 
populacional de perfilhos muda abruptamente, e não gradualmente, de uma inclinação maior que $-3 / 2$ para uma reta de inclinação $-3 / 2$ (Matthew et al., 1995). Segundo Matthew et al. (1999), o ponto em que essas duas retas se cruzam parece ter um significado biológico no sentido de que definiria um limite máximo de plasticidade para o tamanho do perfilho em um dado cultivar ou espécie de planta forrageira ( $d i$ na Figura 1). Por exemplo, para azevém perene esse ponto ocorreu em densidades de 19.950 e 5.010 perfilhos por metro quadrado para genótipos britânicos e neozelandeses, respectivamente (Matthew et al., 1999). Isso indica uma tendência de que cultivares da Nova Zelândia tenham perfilhos maiores e menores densidades populacionais que cultivares britânicos; uma observação que segundo Matthew et al. (1999) poderia ser útil para agricultores.

Dessa forma o objetivo deste trabalho foi verificar a existência do mecanismo de compensação tamanho/densidade populacional de perfilhos em pastagens de Cynodon sob regime de lotação contínua e taxa de lotação variável. Para isso foram realizadas medições de biomassa na aérea total, densidade populacional de perfilhos, massa por perfilho, massa de folha por perfilho e área foliar por perfilho. A partir dessas medições foram realizados cálculos de IAF, volume por perfilho, relação folha:haste por perfilho e razão área foliar: volume por perfilho(R). 


\section{MATERIAL E MÉTODOS}

\subsection{Material}

\subsubsection{Espécie vegetal}

Segundo Mitidieri (1983), as espécies em estudo classificam-se, de acordo com o "Sistema Engler", como: divisão Angiospermae; classe Monocotyledoneae; ordem Graminales; família Gramineae; subfamília Eragrostideae e tribo Chlorideae. São plantas pertencentes ao gênero Cynodon; espécie Cynodon dactylon cv 'Florakirk', Cynodon spp. cv 'Tifton-85 e Cynodon spp. cv. 'Coastcross'.

\subsubsection{Local do experimento}

O ensaio foi conduzido na Unidade Experimental de Plantas Forrageiras (UEPF), em área do Departamento de Produção Animal da Escola Superior de Agricultura "Luiz de Queiroz", Universidade de São Paulo, no município de Piracicaba, Estado de São Paulo, localizado a $22^{\circ} 42^{\prime}$ ' 30" latitude sul, $47^{\circ} 38^{\prime}$ '00" longitude oeste e $546 \mathrm{~m}$ de altitude (Ometto, 1989). O período experimental foi de 15 de dezembro de 1998 a 4 de julho de 1999, sendo realizadas, durante esse período, quatro coletas de dados nas seguintes datas: 15/12/98, 25/01/99, 04/04/99 e 04/07/99. 


\subsubsection{Solo da área experimental}

O experimento foi instalado em solo classificado com terra roxa estruturada eutrófica, com horizonte A moderado de textura argilosa/muito argilosa. O resultado da análise de solo realizada antes do estabelecimento dos pastos encontra-se na Tabela 1. Devido à elevada fertilidade não foram realizadas práticas de calagem nem adubações potássicas ou fosfatadas no momento da implantação do experimento.

Tabela 1. Características químicas do solo da área experimental.

\begin{tabular}{cccccccccc}
\hline $\mathrm{pH}$ & $\mathrm{M} . \mathrm{O}$. & $\mathrm{P}$ & $\mathrm{K}$ & $\mathrm{Ca}$ & $\mathrm{Mg}$ & $\mathrm{H}+\mathrm{Al}$ & $\mathrm{SB}$ & $\mathrm{T}$ & $\mathrm{V}$ \\
$\mathrm{CaCl}_{2}$ & $\mathrm{~g} \cdot \mathrm{dm}^{-3}$ & mg.dm & $-\mathrm{dm}^{-3}$ & & & & & \\
\hline 5,4 & 37,0 & 99 & 4,6 & 75 & 26 & 30 & 106 & 136 & 78,0 \\
\hline
\end{tabular}

\subsubsection{Clima}

Conforme o sistema Köppen, o clima da região de Piracicaba pode ser classificado como Cwa, isto é, mesotérmico úmido, subtropical de inverno seco, onde a temperatura do mês mais frio é inferior a $18{ }^{\circ} \mathrm{C}$ e a do mês mais quente ultrapassa os 22 ${ }^{\circ} \mathrm{C}$ (Brasil, 1960). Os dados climáticos referentes ao período experimental encontram-se na Tabela 2 e nas Figuras 3, 4 e 5. Os dados foram obtidos no posto meteorólogico do Departamento de Ciências Exatas da ESALQ-USP, distante cerca de $500 \mathrm{~m}$ da área experimental. 
Tabela 2. Temperaturas médias mensais do ar (máxima média, mínima média e média), precipitação pluvial e insolação diária média durante o período experimental (de novembro/98 à julho/99) e comparação com os dados dos últimos 80 anos.

\begin{tabular}{|c|c|c|c|c|c|}
\hline \multirow[b]{2}{*}{ Mês/ano } & \multicolumn{3}{|c|}{ Temperatura $\left({ }^{\circ} \mathrm{C}\right)$} & \multirow{2}{*}{$\begin{array}{l}\text { Precipitação } \\
\text { média } \\
\text { (mm chuva) }\end{array}$} & \multirow{2}{*}{$\begin{array}{c}\text { Insolação } \\
\text { média* } \\
\text { (h/dia) }\end{array}$} \\
\hline & $\begin{array}{l}\text { Máxima } \\
\text { média }\end{array}$ & $\begin{array}{l}\text { Mínima } \\
\text { média }\end{array}$ & Média & & \\
\hline Outubro/98 & 27,06 & 16,33 & 21,70 & 183,10 & 5,43 \\
\hline Média (80 anos - outubro ) & 28,90 & 15,57 & 22,23 & 111,28 & 6,87 \\
\hline Novembro/98 & 30,04 & 16,45 & 23,24 & 26,60 & 7,79 \\
\hline Média (80 anos - novembro) & 29,57 & 16,68 & 23,09 & 130,01 & 7,42 \\
\hline Dezembro/98 & 30,01 & 19,21 & 24,61 & 292,60 & 6,06 \\
\hline Média (80 anos - dezembro) & 29,61 & 18,15 & 23,87 & 200,16 & 6,58 \\
\hline Janeiro/99 & 31,42 & 18,98 & 25,20 & 210,80 & 7,70 \\
\hline Média (80 anos - janeiro) & 29,96 & 18,19 & 24,05 & 142,45 & 6,84 \\
\hline Fevereiro/99 & 30,73 & 20,05 & 25,41 & 198,30 & 5,37 \\
\hline Média (80 anos - fevereiro) & 30,23 & 19,02 & 24,61 & 185,89 & 6,54 \\
\hline Março/99 & 31,42 & 18,98 & 25,20 & 210,80 & 7,70 \\
\hline Média (80 anos - março) & 29,96 & 18,19 & 24,05 & 142,45 & 6,84 \\
\hline Abril/99 & 28,52 & 15,20 & 21,86 & 89,00 & 8,09 \\
\hline Média (80 anos - abril) & 28,32 & 15,36 & 21,81 & 64,79 & 7,50 \\
\hline Maio/99 & 25,42 & 11,18 & 18,30 & 51,30 & 7,45 \\
\hline Média (80 anos - maio) & 26,09 & 12,08 & 19,06 & 52,66 & 7,25 \\
\hline Junho/99 & 23,87 & 11,04 & 17,45 & 68,60 & 5,98 \\
\hline Média (80 anos - junho) & 24,89 & 10,28 & 17,57 & 44,47 & 7,09 \\
\hline Julho/99 & 26,38 & 11,99 & 19,18 & 2,70 & 6,70 \\
\hline Média (80 anos - julho) & 25,26 & 9,51 & 17,38 & 26,76 & 7,85 \\
\hline
\end{tabular}

Fonte: Arquivos do Departamento de Ciências Exatas - ESALQ/USP (1999)

* Dados históricos de 77 anos

\subsubsection{Animais}

Para implantação e manutenção dos tratamentos experimentais foram utilizados ovinos mestiços deslanados, com grau variável de sangue da raça Santa Inês, e provenientes do rebanho do setor de Ovinocultura da ESALQ. 


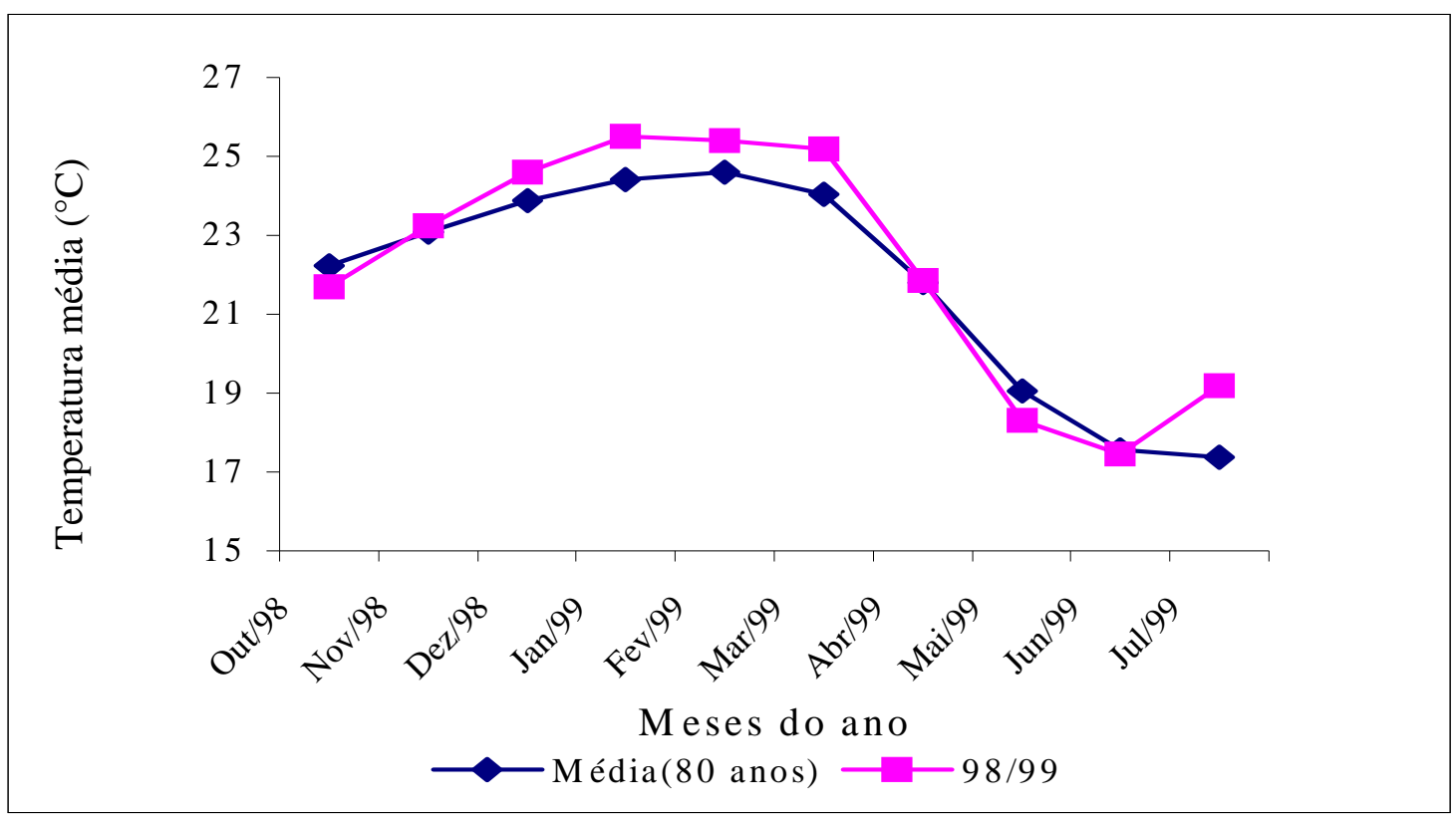

Figura 3 - Distribuição das temperaturas médias durante o período experimental (Outubro/98 a Julho/99) comparadas com aquelas dos últimos 80 anos.

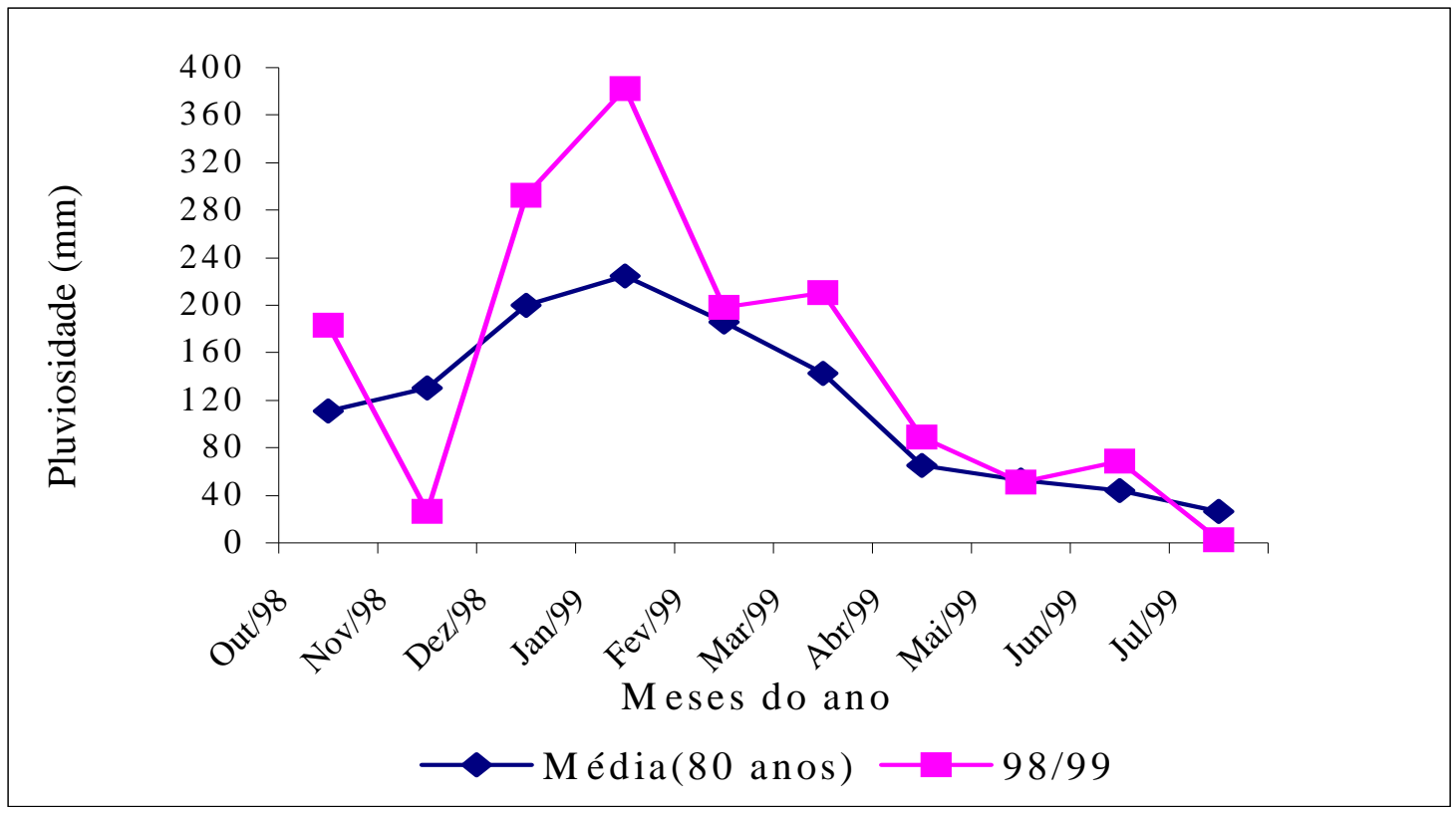

Figura 4 - Distribuição da precipitação durante o período experimental (Outubro/98 à Julho/99) comparada com aquela dos últimos 80 anos. 


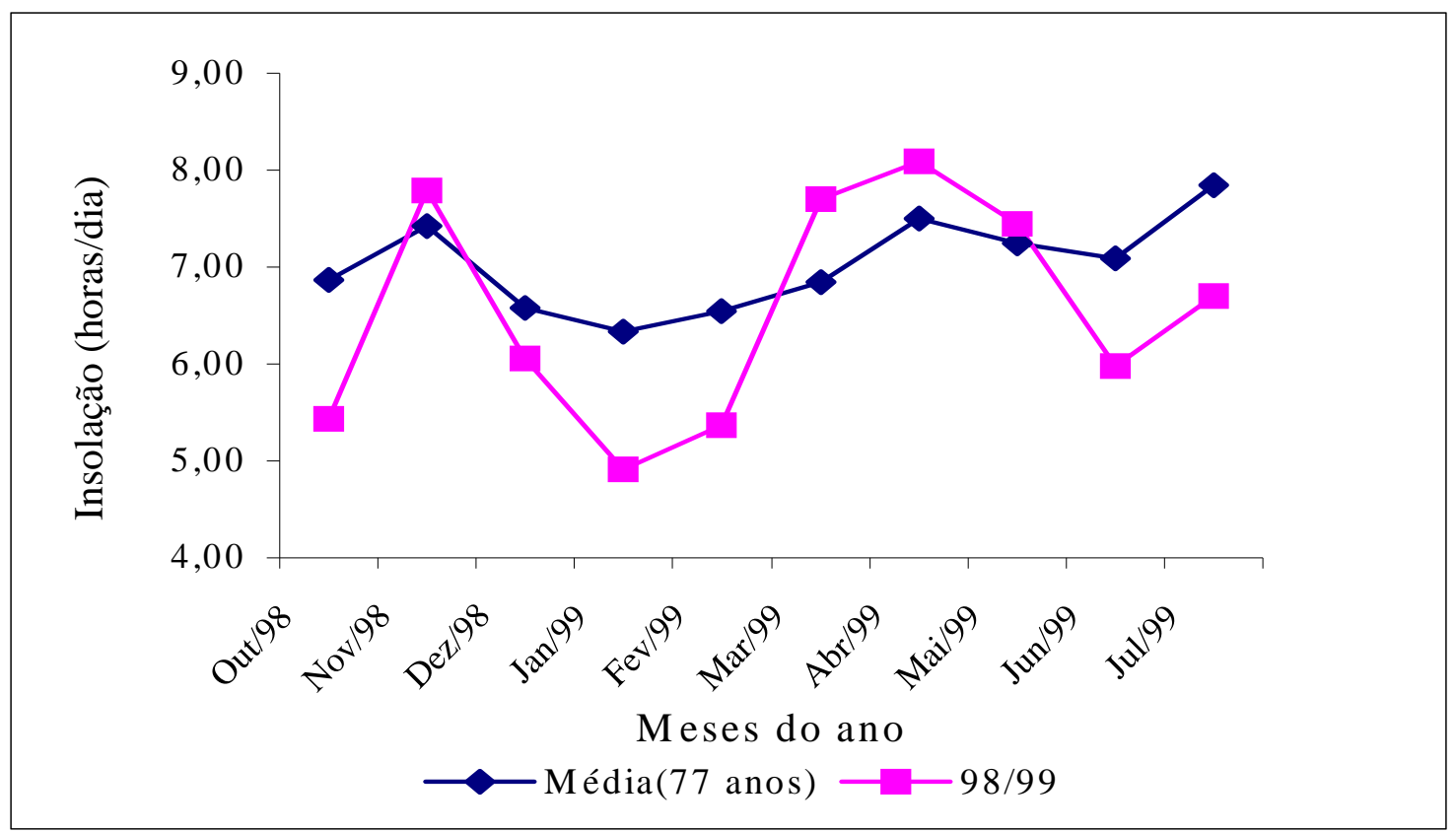

Figura 5 - Distribuição das insolações médias durante o período experimental (Outubro/98 à Julho/99) comparadas com aquelas dos últimos 77 anos.

\subsubsection{Pastagens}

Os pastos foram implantados em março de 1996 através de mudas, sendo que, devido às adversidades climáticas e ao baixo percentual de pegamento, fez-se o replantio de algumas parcelas durante os meses de fevereiro e março de 1997. Em várias ocasiões durante o estabelecimento fez-se necessário a limpeza da área em virtude da infestação com plantas invasoras, especialmente Brachiaria decumbens Stapf, Cyperus spp., Panicum maximum Jacquin e Cynodon dactylon (Linnaeus) Persoon (grama-seda). Adubações nitrogenadas foram realizadas durante o decorrer do ano de 1997, as quais totalizaram $150 \mathrm{~kg} \mathrm{~N} \mathrm{ha}^{-1}$ na forma de sulfato de amônio.

Em janeiro de 1998 realizou-se um corte de uniformização, seguido de uma adubação com $40 \mathrm{~kg} \mathrm{~N} \mathrm{ha}^{-1}$ na forma de sulfato de amônio, além do controle de invasoras. Em fevereiro de 1998 a área experimental sofreu uma infestação de lagarta do cartucho (Spodoptera frugiperda Smith) e cigarrinha das pastagens (Deois spp. e Zulia 
entreriana Berg.), a qual foi controlada com o inseticida Deltamethrin, na dosagem de 7,5 gramas de ingrediente ativo/hectare, juntamente com Metharizium, na dosagem de 800 gramas/hectare, na data de 19 de fevereiro de 1998. Um novo corte de uniformização foi então realizado em março de 1998. No entanto, ocorreu um novo ataque da lagarta juntamente com a cigarrinha das pastagens (Deois spp. e Zulia entreriana), e nova aplicação de inseticida foi feita, em 2 de abril de 1998, utilizando-se, desta vez, Chlorpyrifos, na dosagem de 1L/hectare. Após o controle da infestação de pragas as pastagens foram deixadas rebrotar até que as alturas especificadas para cada tratamento fossem atingidas, oportunidade na qual foi iniciado o pastejo. Foram decorridos cerca de seis meses (junho a setembro/1998) com os pastos sendo mantidos sob os regimes de desfolha planejados antes que a primeira avaliação fosse realizada.

\subsection{Métodos}

\subsubsection{Delineamento experimental e tratamentos}

O ensaio foi realizado seguindo um delineamento em blocos completos casualizados, com parcelas subdivididas (split-plot). Os tratamentos corresponderam a combinações entre três cultivares de Cynodon spp. ('Tifton-85', 'Florakirk' e 'Coastcross'), os quais foram alocados às parcelas, e quatro condições de pasto geradas por ovinos sob regime de lotação contínua e taxa de lotação variável, alocadas nas subparcelas. Cada condição de pasto correspondeu a uma altura média do relvado de 5, 10, 15 e $20 \mathrm{~cm}$ mantida "constante" através da adição ou retirada de animais das unidades experimentais durante o transcorrer do experimento. Nesse arranjo foram utilizadas quatro repetições. Assim, o ensaio apresentou um total de 48 unidades experimentais (4 blocos x 12 unidades/bloco) com uma área de, aproximadamente, $400 \mathrm{~m}^{2}$ cada, separadas por telas de 1,20 m de altura para delimitação dos piquetes (unidades experimentais) e contenção dos animais. A área experimental total compreendeu 2,0 ha (Figura 6, Foto 1). 


\begin{tabular}{|c|c|c|c|c|c|c|c|c|c|c|c|}
\hline \multicolumn{3}{|c|}{ BLOCO I } & \multicolumn{3}{|c|}{ BLOCO II } & \multicolumn{3}{|c|}{ BLOCO III } & \multicolumn{3}{|c|}{ BLOCO IV } \\
\hline T 10 & F 15 & C 10 & F 05 & T 10 & C 10 & F 20 & T 15 & C 10 & T 20 & F 05 & C 05 \\
\hline T 15 & F 10 & C 05 & F 10 & T 15 & C 20 & F 05 & T 20 & C 15 & T 15 & F 10 & $\overline{C 20}$ \\
\hline T 20 & F 05 & C 15 & F 15 & T 20 & C 15 & F 15 & T 10 & C 20 & T 10 & F 20 & C 10 \\
\hline T 05 & F 20 & C 20 & F 20 & T 05 & C 05 & F 10 & T 05 & C 05 & T 05 & F 15 & $\overline{C ~} 15$ \\
\hline
\end{tabular}

Figura 6 - Representação esquemática da distribuição dos tratamentos na área experimental. T: Tifton 85; F: Florakirk; C: Coastcross. Alturas (cm): 5, 10,15 e 20.

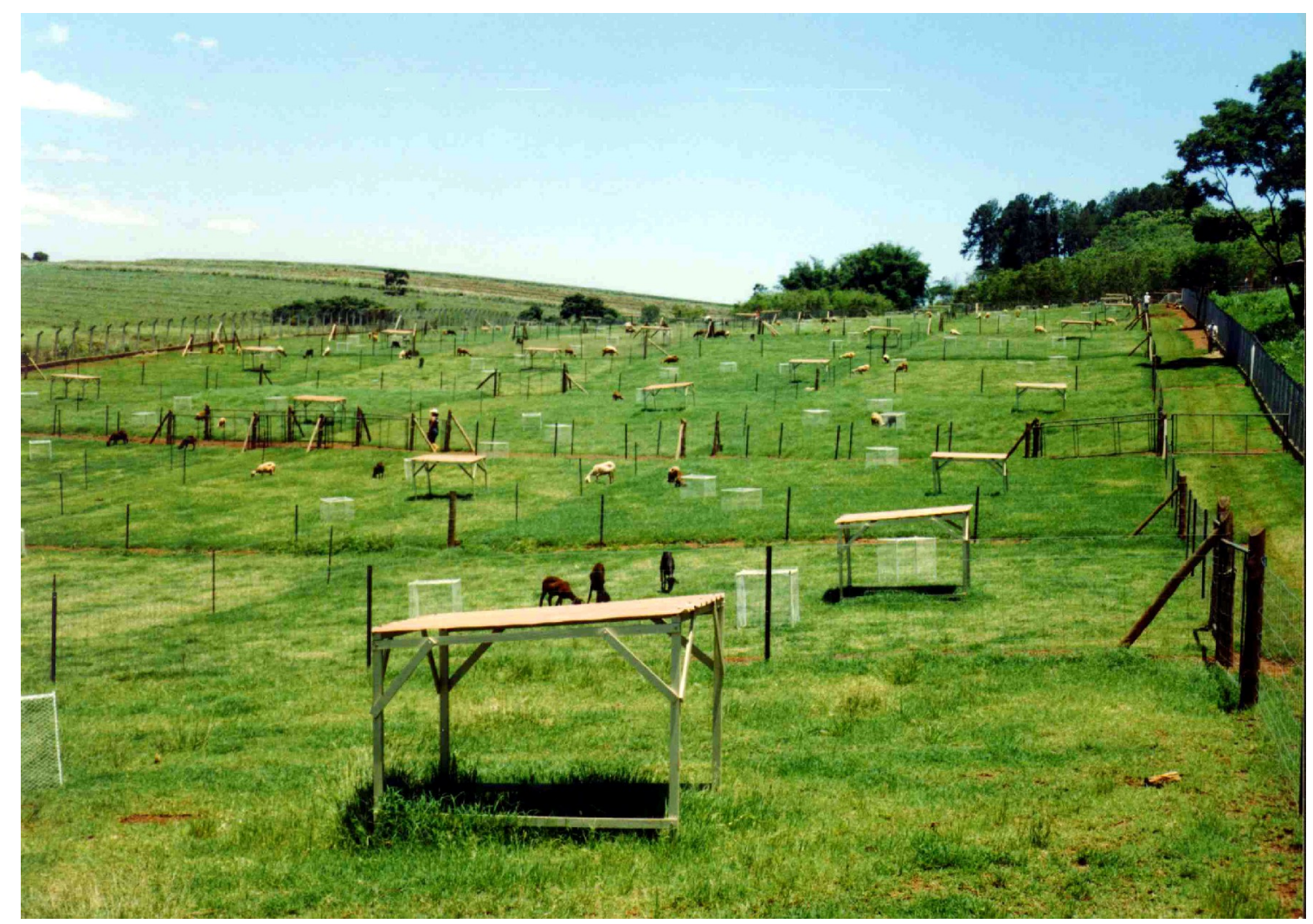

Foto 1 - Vista geral da área experimental após a implantação e início do experimento

\subsubsection{Instalação e monitoramento das condições experimentais}

Em 3 de junho de 1998 os animais foram alocados às unidades experimentais que haviam atingido a altura predeterminada para cada tratamento. À medida que as demais unidades experimentais atingiam a altura desejada, animais eram colocados, 
dando início ao pastejo. No ano de 1998 foram realizadas 4 adubações nitrogenadas com sulfato de amônio. A primeira em 8 de julho (40 $\mathrm{kg} \mathrm{N} \mathrm{ha}^{-1}$ ), a segunda em 19 de setembro (40 kg N ha ${ }^{-1}$ ), a terceira em 21 de outubro $\left(50 \mathrm{~kg} \mathrm{~N} \mathrm{ha}^{-1}\right)$ e a quarta em $7 \mathrm{de}$ dezembro (25 $\mathrm{kg} \mathrm{N} \mathrm{ha}^{-1}$ ). Em 1999, até a última coleta de dados em julho, foram realizadas duas adubações nitrogenadas. A primeira em 23 de fevereiro (50 kg N ha-1) e a segunda em 5 de março $\left(75 \mathrm{~kg} \mathrm{~N} \mathrm{ha}^{-1}\right)$. As quantidades de fertilizante aplicadas foram dimensionadas a fim de que um acúmulo mínimo de forragem pudesse ser obtido para manter pelo menos dois animais em cada unidade experimental.

A condição dos pastos (altura média do relvado) foi monitorada semanalmente através da tomada de 20 leituras em cada unidade experimental com o "rising plate meter", ou prato ascendente, duas vezes por semana, obtendo-se a altura comprimida média. Uma vez por mês era feita a calibração da altura comprimida com a altura não comprimida (régua), gerando o valor de altura usado como referência para o monitoramento dos tratamentos (Foto 2). Animais foram adicionados ou removidos das unidades experimentais no caso da altura estar acima ou abaixo da desejada, respectivamente.

\subsubsection{Calibração entre a altura comprimida e altura não comprimida}

Uma vez por mês era realizada a calibração entre a altura comprimida e a altura não comprimida do pasto. Durante a calibração eram realizadas 20 medições com o "rising plate meter" e 12 leituras de altura não comprimida por unidade experimental. Esta última altura era medida utilizando-se uma transparência que, quando colocada sobre a pastagem, tinha sua altura mais baixa e a mais alta em relação ao solo medidas com uma régua. Assim, cada leitura não comprimida correspondia à média entre os valores mais alto e mais baixo. Com os valores das alturas eram gerados fatores mensais de conversão que, multiplicados pelas alturas comprimidas, forneciam a altura da pastagem utilizada como referência para o monitoramento da condição do pasto e ajustes nas taxas de lotação (Foto 2). 


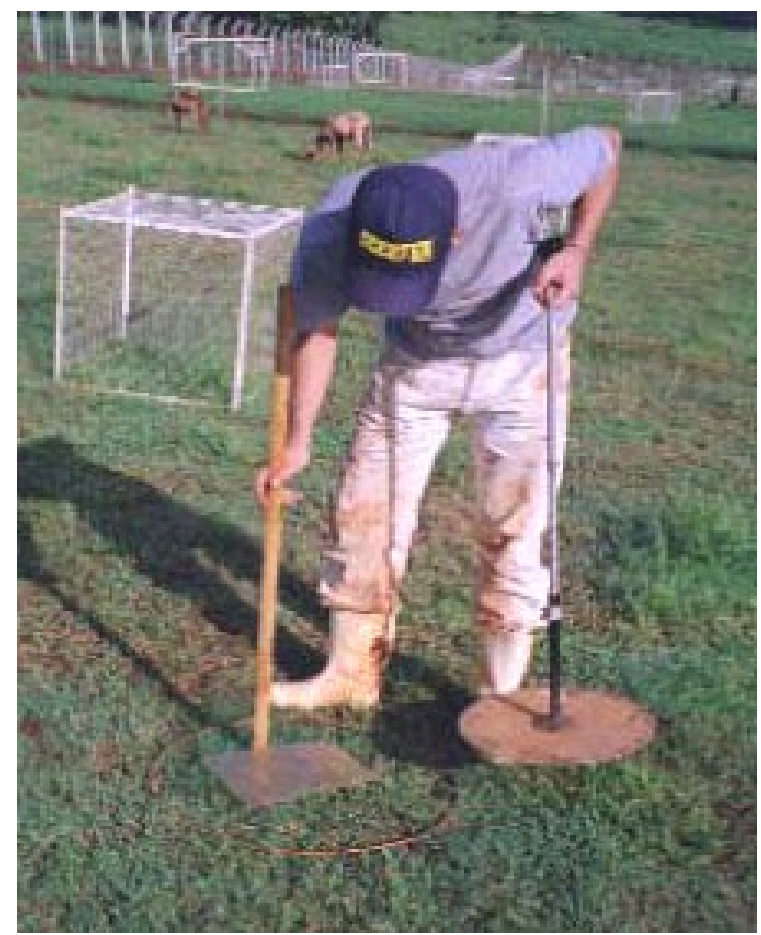

Foto 2 - Medição da altura do pasto com transparência e régua (altura não comprimida) e com o "rising plate meter" (altura comprimida).

\subsection{Avaliação dos parâmetros da compensação tamanho/densidade populacional de perfilhos}

Inicialmente, nas medições que envolveram avaliações individuais de perfilhos, a amostragem foi realizada com um "quadrado" de 8,5 x $21 \mathrm{~cm}$. Após a $1^{\text {a }}$ coleta, verificou-se que o tamanho da área de amostragem poderia ser reduzido sem prejuízos de precisão e com benefícios de economia e racionalização de tempo e mão-de-obra. Assim, a partir da $2^{\underline{a}}$ coleta, a amostragem foi realizada utilizando-se um "quadrado" de $8,5 \times 14 \mathrm{~cm}$, que correspondia a uma área de $0,0125 \mathrm{~m}^{2}$. Dentro de cada unidade experimental foram cortadas duas amostras, correspondentes às alturas do tratamento em questão, utilizando-se tesouras e estiletes e, em seguida, todo material cortado foi colocado em sacos plásticos previamente umedecidos e acondicionados em caixa de 
isopor com gelo. Este procedimento foi realizado a fim de minimizar os processos de respiração e transpiração das plantas. Todo material coletado (total de 96 amostras) foi levado ao laboratório e armazenado em câmara fria para posterior processamento.

\subsubsection{Avaliação da biomassa aérea total}

Para avaliação da biomassa total por área $\left(\mathrm{kg}\right.$ de $\left.\mathrm{MS} / \mathrm{m}^{2}\right)$ foram utilizados 2 círculos de $0,25 \mathrm{~m}^{2}$ cada. Os círculos foram colocados em locais da unidade experimental que encontravam-se na altura do tratamento sendo avaliado, sendo a massa de forragem dentro deles cortada no nível do solo com o auxílio de tosquiadeiras de carneiro alimentadas por gerador a gasolina. As amostras foram acondicionadas em sacos plásticos e levadas para câmara fria. Cada amostra foi lavada, colocada em bandejas de metal e levada à estufa para secagem a $65{ }^{\circ} \mathrm{C}$ por dois dias e, posteriormente, pesada.

\subsubsection{Densidade populacional de perfilhos ( $n^{0}$ de perfilhos $/ \mathrm{m}^{2}$ )}

O protocolo experimental inicial previa a determinação da densidade populacional de perfilhos através da contagem dos perfilhos contidos em cada "quadrado" (seção 3.3). No entanto, após a obtenção dos resultados, verificou-se que os valores encontrados possuíam, de uma maneira geral, um comportamento anômalo, não refletindo o que de fato estava acontecendo, principalmente por ocasião da última coleta, quando boa parte dos pastos encontrava-se em florescimento. Esse comportamento foi creditado à formação de estruturas típicas de pastos de Cynodon denominadas "rosetas" (Foto 3). Estas são estruturas que aparecem em pastos de Cynodon, principalmente naqueles mantidos acima de $10 \mathrm{~cm}$, onde há a formação de dezenas de perfilhos sobre uma haste, normalmente muito lignificada. Via de regra essa estrutura é formada em pastos reprodutivos que tiveram a inflorescência decapitada. Essa formação acaba por 
inflacionar o número de perfilhos por unidade de área, distorcendo os resultados. Assim, pastos de $20 \mathrm{~cm}$, por exemplo, podem apresentar uma densidade populacional de perfilhos superior a pastos de $5 \mathrm{~cm}$. Como a área do "quadrado" utilizado para avaliar este parâmetro era pequena $\left(0,0125 \mathrm{~m}^{2}\right)$, ocorreu que, em determinadas situações, não foi possível abranger a heterogeneidade do pasto, o que inflacionou a contagem de perfilhos e prejudicou a precisão e exatidão dos dados.

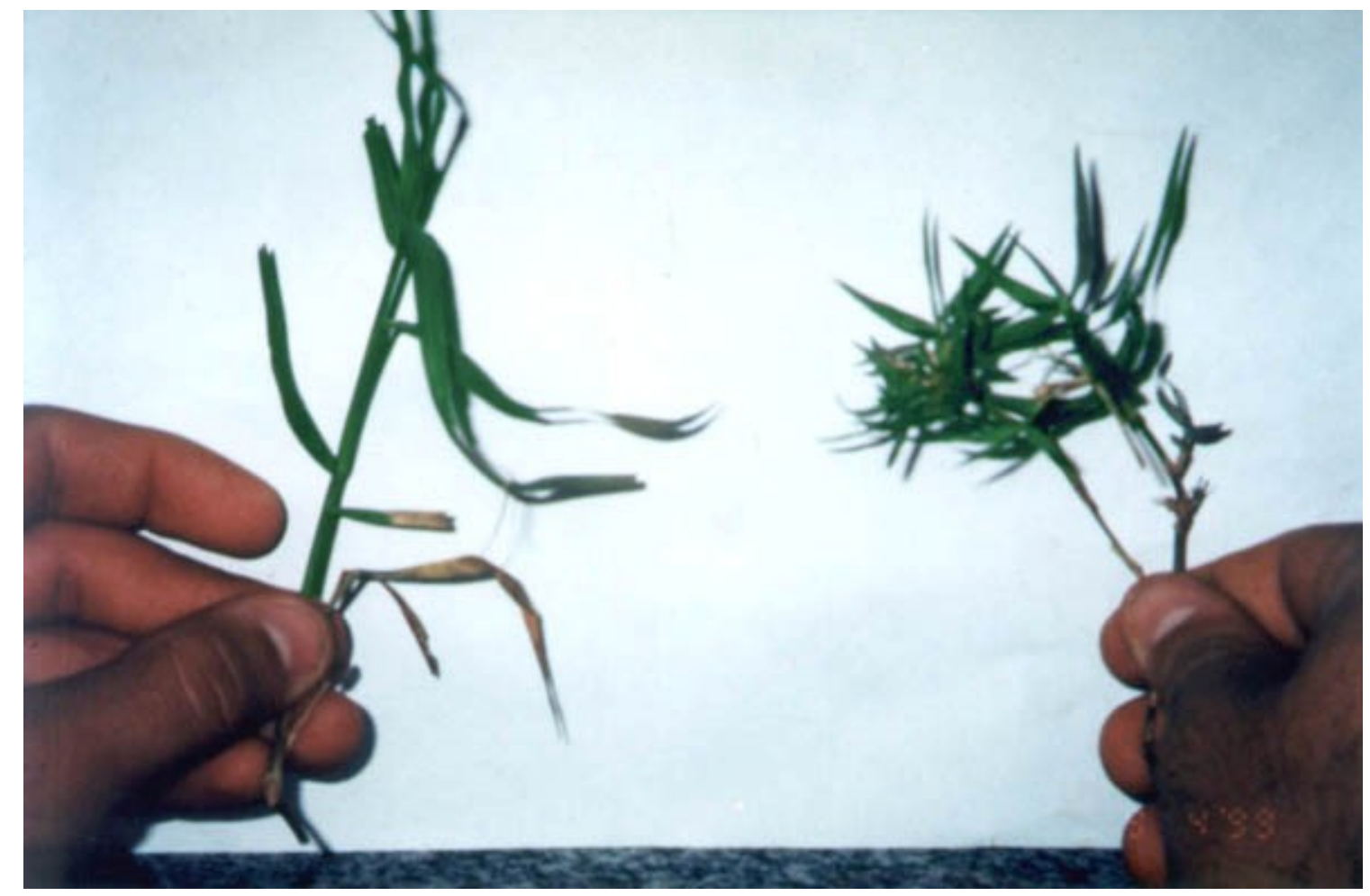

Foto 3 - Formação de "rosetas" em pastos de Cynodon (direita)

Dessa forma, com o objetivo de corrigir tal limitação da técnica, a densidade populacional de perfilhos (DPP) foi obtida através da seguinte relação matemática:

$$
D P P=\frac{M F\left(k g / m^{2}\right)}{M P(k g)} \text { onde; }
$$

$\mathrm{MF}=$ biomassa aérea total e MP = massa média por perfilho.

Os novos valores de densidade populacional obtidos foram muito próximos àqueles observados pelo procedimento original quando os pastos encontravam-se em seu 
estádio vegetativo, e resultaram num melhor ajuste dos valores naquelas situações onde a ocorrência de "rosetas" foi verificada. Em situações de florescimento intenso, no entanto, o método também mostrou-se ineficaz.

\subsubsection{Massa de folha, massa "fresca" e massa seca por perfilho}

Para avaliação da massa "fresca" e massa seca por perfilho foram selecionados 20 perfilhos ao acaso provenientes das amostras utilizadas para contagem do número de perfilhos ("quadrados" - seção 3.3). Esses 20 perfilhos foram pesados em balança digital marca OHAUS, modelo Explorer. A divisão do valor obtido por vinte forneceu o valor da massa fresca média por perfilho.

Após pesagem, as folhas verdes de cada perfilho foram destacadas, acondicionadas em saquinhos de papel e levadas à estufa a $65^{\circ} \mathrm{C}$ por 48 horas. $\mathrm{O}$ mesmo procedimento foi realizado com a outra porção (haste + folhas mortas). Depois de seco o material foi pesado em balança digital marca OHAUS, modelo Explorer, e o valor da massa média por perfilho foi o resultado do quociente entre a soma de folhas + haste (folhas mortas inclusive) e o número total de perfilhos (20). O valor da massa média de folhas por perfilho foi o resultado da divisão do valor da pesagem da massa total de folhas por 20 .

\subsection{4 Área foliar média por perfilho $\left(\mathrm{cm}^{2} /\right.$ perfilho $)$}

Antes de serem acondicionadas em saquinhos de papel, as folhas tiveram sua área foliar medida em aparelho integrador de área foliar, marca LI-COR, modelo LI3100 (Foto 4). Dessa forma, a área foliar média por perfilho foi o resultado do quociente entre o valor obtido no integrador e o número de perfilhos analisados (20). 


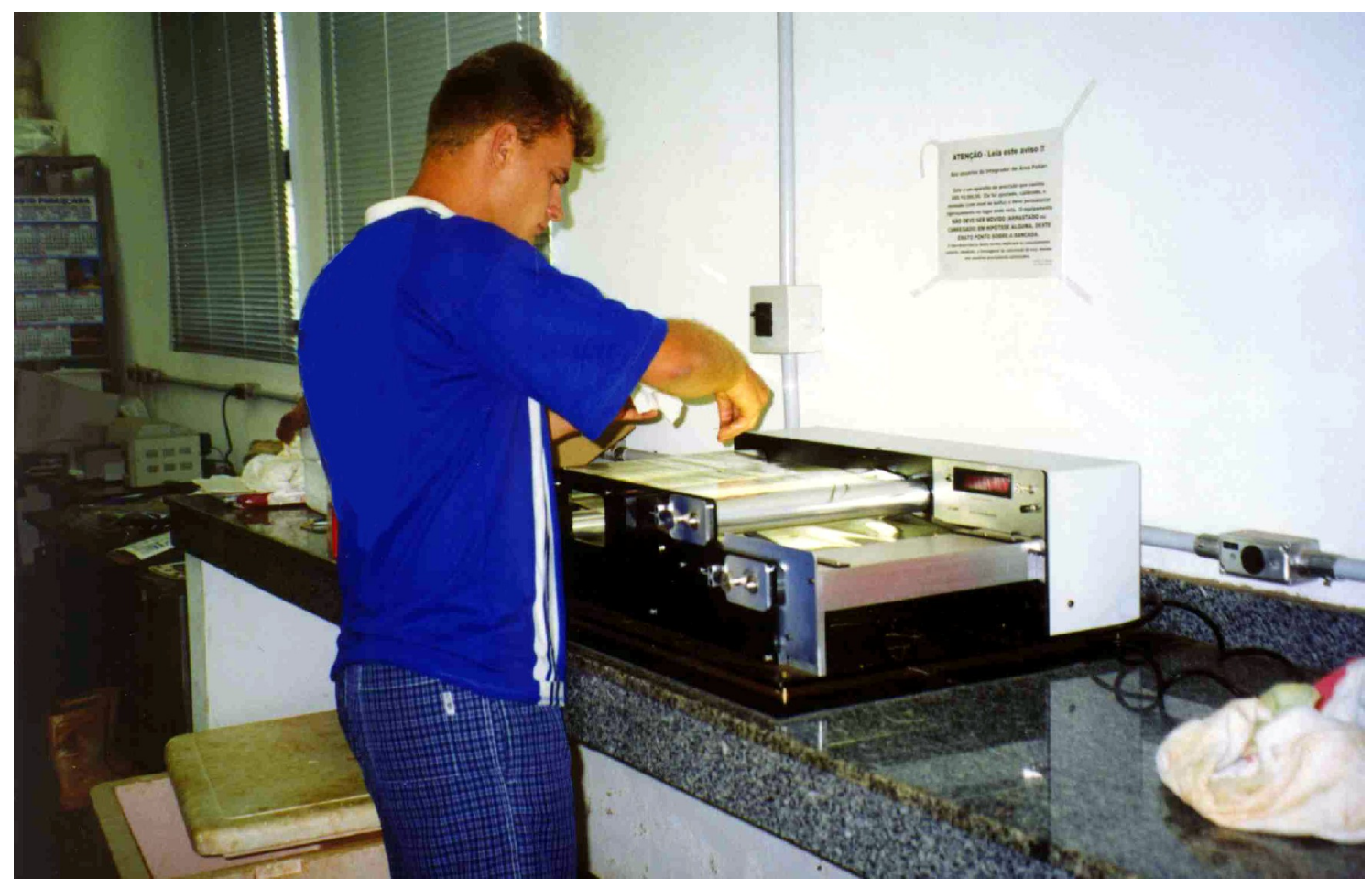

Foto 4 - Medição da área foliar de perfilhos em aparelho integrador de área marca LI-COR, modelo LI-3100.

\subsection{5 Índice de área foliar (IAF)}

O índice de área foliar do pasto foi calculado através da seguinte relação matemática:

$$
I A F=D P P \times A r \text { onde; }
$$

$\mathrm{DPP}=$ número de perfilhos por metro quadrado, $\mathrm{e}$

$\mathrm{Ar}=$ área foliar média por perfilho (em metros quadrados). 


\subsubsection{Estimativa do volume médio por perfilho $\left(\mathrm{cm}^{3} /\right.$ perfilho)}

Várias tentativas foram realizadas com o intuito de se medir o volume médio por perfilho. A primeira tentativa foi baseada na técnica do deslocamento de líquido. A idéia era que com a imersão de um determinado número de perfilhos num recipiente com um volume conhecido de água fosse possível, através da variação em volume do líquido, conhecer-se o volume médio dos mesmos. Essa técnica não se mostrou eficiente pelo pequeno deslocamento de líquido observado e, consequentemente, a dificuldade em sua leitura de maneira precisa e exata, o que poderia resultar em graves erros na estimativa final.

A segunda tentativa foi feita calculando-se o volume através de uma fórmula matemática que expressa a área de um corpo qualquer dado simplesmente a sua massa $(\mathrm{A}=0,026 \mathrm{x}$ massa do corpo) (Campbell, 1977). Pensou-se que o volume poderia ser estimado simplesmente multiplicando-se a área pela altura do perfilho. Essa técnica também não se mostrou efetiva devido ao fato de que a fórmula utilizada além de ser válida apenas para cálculos de área, não foi desenvolvida para cálculos com plantas e sim para animais.

Finalmente, a técnica utilizada para calcular o volume médio por perfilho foi baseada na imersão de perfilhos em líquidos de densidades aparente conhecidas. Assim, perfilhos flutuaram quando imersos em água e admitiu-se, portanto, que sua densidade teria que ser menor que $1000 \mathrm{~kg} / \mathrm{m}^{3}$; a densidade da água. Num segundo momento colocou-se outra grande quantidade de perfilhos num recipiente com óleo lubrificante, cuja densidade (informada pelo fabricante) era de $902 \mathrm{~kg} / \mathrm{m}^{3}$ a $20{ }^{\circ} \mathrm{C}$ (condições de temperatura ambiente no laboratório foram ajustadas para $20{ }^{\circ} \mathrm{C}$ ). Os perfilhos quando colocados no óleo afundaram. Com isso concluiu-se que os perfilhos deveriam ter uma densidade média entre 902 e $1000 \mathrm{~kg} / \mathrm{m}^{3}$. Assim, admitiu-se que os perfilhos teriam uma

densidade de aproximadamente $950 \mathrm{~kg} / \mathrm{m}^{3}$. Este valor mostrou-se satisfatoriamente robusto uma vez que se fosse cometido um erro na estimativa da densidade este resultaria numa variação de apenas $5 \%$ nas estimativas de volume. A confirmação desse resultado veio através de discussões com pesquisadores neozelandeses que encontraram, 
através de técnica semelhante, uma densidade de $900 \mathrm{~kg} / \mathrm{m}^{3}$ para perfilhos de azevém perene (Matthew, 2000²).

Dessa forma, o cálculo do volume médio por perfilho foi obtido através da seguinte relação:

$$
\text { Densidade }=\frac{\text { Peso }}{\text { Volume }}
$$

Como eram conhecidas a densidade e a massa "fresca" por perfilho, calculou-se o volume médio por perfilho.

\subsubsection{Cálculo da razão área foliar:volume por perfilho $(\mathbf{R})$}

A relação adimensional entre área foliar média e volume médio por perfilho proposta por Sackville Hamilton et al. (1995) foi calculada da seguinte maneira:

$$
R=\frac{A r^{3 / 2}}{V} \quad \text { onde; }
$$

$\mathrm{Ar}=$ área foliar média por perfilho (em metros quadrados), e

$\mathrm{V}=$ volume médio por perfilho (em metros cúbicos)

(a área foliar é elevada à potência 3/2 a fim de que o valor $\mathrm{R}$ se torne adimensional).

\subsection{Regressão Log (densidade populacional de perfilhos) x Log (massa por perfilho)}

As regressões entre densidade populacional de perfilhos e massa média por perfilho foram realizadas através das médias correspondentes a cada tratamento, totalizando, dessa forma, quatro pares de dados para cada cultivar em cada época de avaliação.

\footnotetext{
${ }^{2}$ Matthew, C. (Massey University, Nova Zelândia). Comunicação pessoal, 2000.
} 


\subsection{Cálculo de $C_{a}$ e $C_{r}$ e da distância entre os pontos obtidos e a reta teórica de inclinação $-3 / 2$}

Os cálculos das correções para predição da inclinação da reta foram realizados utilizando-se o procedimento descrito por Matthew et al. (1995) onde:

$$
C_{a}=\frac{\Delta \log \left(I A F^{3 / 2}\right)}{\Delta \log (D P P)} \quad \text { e } \quad C_{r}=\frac{\Delta \log (R)}{\Delta \log (D P P)} \text { onde; }
$$

IAF = índice de área foliar do pasto,

$\mathrm{DPP}=$ número de perfilhos por metro quadrado, e

$\mathrm{R}=$ razão entre área foliar e volume do perfilho.

As correções foram calculadas utilizando-se os dois extremos de altura de pasto estudados, ou seja, 5 e $20 \mathrm{~cm}$. A distância entre os pontos obtidos na relação $\log x \log$ entre massa e densidade populacional de perfilhos e a reta teórica de IAF constante (3/2) foi calculada através de princípios de trigonometria, geometria plana e analítica (Figura 7).

Assumiu-se:

- uma reta com inclinação -3/2 (coeficiente angular) forma um ângulo $\alpha$ de $56,3^{\circ}$ com o eixo horizontal (x) (coeficiente angular reta $=$ tangente do ângulo).

- $\beta$ é o complemento de $\alpha$ para $90^{\circ}, \log 0 \beta=90-\alpha=90-56,3=$ $33,7^{\circ}$.

- a hipotenusa do triângulo retângulo formado é a distância vertical entre qualquer ponto observado $(\mathrm{x}, \mathrm{y})$ e um ponto de mesma coordenada (x) sobre a reta $-3 / 2$ (valores obtidos a partir das equações de regressão calculadas).

- a distância "r" de interesse é o cateto oposto ao ângulo $\beta$.

Assim, a distância (em log) de um ponto qualquer e a reta $-3 / 2$ foi calculada através da seguinte relação trigonométrica: 
$\mathrm{r}=$ distância de interesse.

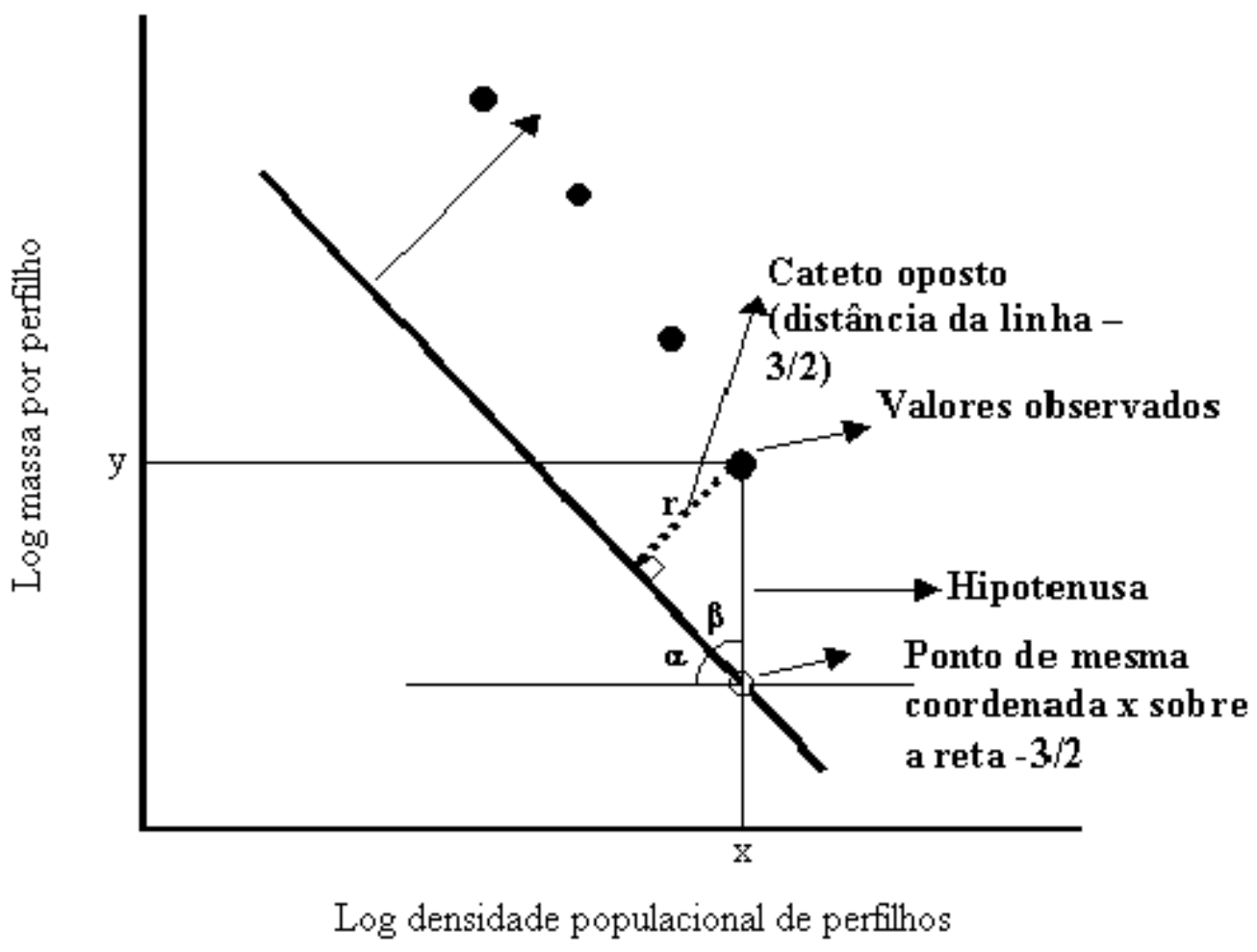

Figura 7 - Representação esquemática do cálculo da distância entre os pontos obtidos e a reta de inclinação teórica $-3 / 2$.

Posteriormente cada ponto (representado pelo seu IAF observado) foi comparado com a distância calculada e uma análise de regressão simples foi realizada a fim de obter-se a relação funcional entre essas variáveis. 


\subsection{Análise estatística}

Os dados foram analisados utilizando-se o PROC GLM (General Linear Models) e o PROC REG do pacote estatístico SAS (Statistical Analysis System), versão 6.12 para Windows. Para a análise de variância dos dados optou-se pelo subprocedimento de medidas repetidas no tempo (Repeated Measures), uma vez que todas as variáveis em estudo foram coletadas de forma sequencial ao longo do período experimental (SAS Institute, 1988). Assim, foi possível detectar-se os efeitos das causas de variação principais (cultivar, bloco, altura), as interações entre elas (bloco x cultivar e altura x cultivar), além dos efeitos de tempo dentro de cada uma das causas de variação principais (mês, mês x cultivar, mês x bloco, mês x altura, mês x cultivar x bloco, mês x altura $\mathrm{x}$ cultivar etc.). Todos os conjuntos de dados foram testados, antes da análise geral global, com a finalidade de assegurar que as quatro prerrogativas básicas da análise de variância (aditividade do modelo, independência dos erros, normalidade dos dados e homogeneidade das variâncias) estavam sendo respeitadas. As médias foram comparadas através do "LSMEANS". 


\section{RESULTADOS E DISCUSSÃO}

\subsection{Densidade populacional de perfilhos}

Houve efeito de data de avaliação $(\mathrm{P}=0,0013)$ e cultivar $(\mathrm{P}=0,0586)$ (Tabela 3$)$ e interação datas de avaliação x altura $(\mathrm{P}=0,0002)$ (Tabela 4). A única diferença entre cultivares ocorreu na $2^{\underline{a}}$ avaliação, onde Tifton-85 apresentou densidades populacionais de perfilhos maiores que Coastcross e Florakirk (Tabela 3). Diferenças em densidade populacional de perfilhos (DPP) entre cultivares de uma mesma espécie já foram relatadas por diversos autores (Langer, 1963; Nabinger \& Medeiros, 1995; Gomide \& Gomide, 1996) e refletem seu potencial genético por apresentarem diferentes valores de filocrono e "site filling" nos ambientes onde vegetam (Zarrough et al., 1984). Outro fator que pode ter contribuído para a maior DPP observada em Tifton-85 (principalmente na $2^{\underline{a}}$ avaliação) foi o alto florescimento ocorrido nos cultivares Florakirk e Coastcross. Diversos pesquisadores (Ong et al., 1978; Korte et al., 1984; Korte, 1986; Hernández Garay et al., 1997; Mitchell et al., 1998) relataram que durante o período de florescimento ocorre uma queda marcante no desenvolvimento de novos perfilhos, estando esse fato relacionado aos eventos fisiológicos ocorridos com a planta forrageira durante essa fase (Langer, 1963; Marshall, 1987; Woodward, 1998). Quanto mais tempo o relvado permanece nesse estádio, menores são as densidades populacionais resultantes. Como pode ser observado (Tabela 4), houve uma tendência de aumento nos valores de densidade populacional de perfilhos ao longo do período experimental. Provavelmente este padrão de resposta esteve associado com o período de estiagem observado em novembro/98 (Tabela 2 e Figura 4), onde foi observada uma redução drástica em precipitação pluvial. A partir daí os níveis normais foram 
restabelecidos e estiveram associados com altas temperaturas, luminosidade e disponibilidade de nutrientes minerais. Carvalho (2000), em experimento concomitante onde se avaliou o padrão demográfico de perfilhamento dos cultivares estudados, verificou altas taxas de mortalidade e baixas taxas de natalidade naquela época do ano. Segundo Langer (1979), a água é um dos fatores de ambiente que interferem no perfilhamento, fato que pode influenciar no balanço líquido entre o aparecimento e a morte de perfilhos e alterar, consequentemente, os valores de DPP na comunidade de plantas (Hodgson, 1990; Da Silva \& Pedreira, 1997, Matthew et al., 1999).

Tabela 3. Densidade populacional de perfilhos (perfilhos $/ \mathrm{m}^{2}$ ) em pastos de Cynodon spp. durante o período experimental.

\begin{tabular}{|c|c|c|c|c|c|}
\hline \multirow[b]{2}{*}{$\begin{array}{l}\text { Datas de } \\
\text { avaliação }\end{array}$} & \multicolumn{3}{|c|}{ Cultivares } & \multirow[b]{2}{*}{ Média } & \multirow[b]{2}{*}{ EPM } \\
\hline & Tifton 85 & Florakirk & Coastcross & & \\
\hline 1 & $11440^{a}$ & $10280^{a}$ & $10540^{a}$ & 10750 & 750 \\
\hline 2 & $15090^{\mathrm{a}}$ & $10930^{\mathrm{b}}$ & $11820^{b}$ & 12610 & 1120 \\
\hline 3 & $14590^{\mathrm{a}}$ & $13230^{\mathrm{a}}$ & $13350^{\mathrm{a}}$ & 13720 & 1050 \\
\hline 4 & $15700^{\mathrm{a}}$ & $12110^{\mathrm{a}}$ & $13930^{\mathrm{a}}$ & 13910 & 1950 \\
\hline
\end{tabular}

Médias na mesma linha seguidas de letras semelhantes não diferem entre si (P>0,10) EPM - Erro padrão da média. Data 1=15/12/98; Data 2=25/01/99; Data 3=07/04/99 e Data 4=04/07/99. 
Tabela 4. Densidade populacional de perfilhos (perfilhos $/ \mathrm{m}^{2}$ ) para as alturas de pasto estudadas.

\begin{tabular}{|c|c|c|c|c|c|c|}
\hline \multirow[b]{2}{*}{$\begin{array}{l}\text { Datas de } \\
\text { avaliação }\end{array}$} & \multicolumn{4}{|c|}{ Altura de pasto $(\mathrm{cm})$} & \multirow[b]{2}{*}{ Média } & \multirow[b]{2}{*}{ EPM } \\
\hline & 5 & 10 & 15 & 20 & & \\
\hline 1 & $14730^{\mathrm{a}}$ & $11570^{a b}$ & $9360^{b}$ & $7360^{b}$ & 10750 & 860 \\
\hline 2 & $14670^{\mathrm{a}}$ & $12910^{a b}$ & $10660^{b}$ & $12220^{a b}$ & 12610 & 1290 \\
\hline 3 & $10980^{b}$ & $17090^{\mathrm{a}}$ & $15210^{\mathrm{a}}$ & $11610^{b}$ & 13720 & 1210 \\
\hline 4 & $14730^{a}$ & $12770^{a}$ & $12150^{\mathrm{a}}$ & $16010^{a}$ & 13910 & 2250 \\
\hline
\end{tabular}

Médias na mesma linha seguidas de letras semelhantes não diferem entre si ( $\mathrm{P}>0,10)$

EPM - Erro padrão da média. Data 1=15/12/98; Data 2=25/01/99; Data 3=07/04/99 e Data 4=04/07/99.

Apesar de não ter sido detectada diferença entre alturas de pasto, pode-se observar que existiu uma tendência para que pastos mais altos $(15$ e $20 \mathrm{~cm})$ apresentassem densidades populacionais de perfilhos menores que pastos mais baixos (5 e $10 \mathrm{~cm}$ ) (Tabela 4), exceção feita à $4^{\underline{a}}$ avaliação. Isto evidencia a competição existente entre perfilhos e corrobora resultados obtidos para plantas de clima temperado, particularmente azevém perene (Grant et al., 1982; Bircham \& Hodgson, 1983; Matthew et al., 1995; Hernández Garay et al., 1999), onde maiores densidades populacionais estiveram associadas com pastos baixos. Essa competição entre perfilhos ocorre particularmente por luz (Lonsdale e Watkinson, 1982; Sackville Hamilton et al., 1995). Num trabalho conduzido na mesma área, de forma concomitante, Fagundes (1999) observou para a altura de pasto de $5 \mathrm{~cm}$ que cerca de $62 \%$ da luz incidente atingia o solo em setembro/98 e que este valor subiu para cerca de 95\% em dezembro/98. Já em pastos mantidos a $20 \mathrm{~cm}$ os valores observados foram bastante inferiores (em torno de $18 \% \mathrm{em}$ agosto/98) chegando, em várias situações, a apenas 3\%. A baixa intensidade luminosa na base do relvado é um dos fatores que poderia interferir com a capacidade de perfilhamento de pastos mantidos mais altos (Langer, 1979). Além disso, as folhas mais baixas, por crescerem num ambiente com pouca luz, têm seu potencial fotossintético 
reduzido, o que pode levar a uma condição de balanço negativo de carbono (respiração > fotossíntese) (Parsons et al., 1983) e acelerar os processos de senescência e morte dessas folhas e dos perfilhos que as sustentam (Westoby, 1984; Sackville Hamilton et al.,1995). Interessante observar que na $3^{\underline{a}}$ avaliação a densidade populacional de perfilhos na altura de $5 \mathrm{~cm}$ foi menor quando comparada com a de $10 \mathrm{~cm}$. Segundo Chapman \& Lemaire (1993), existem limites de plasticidade fenotípica em pastos submetidos a desfolha que não permitem aumentos em densidade populacional de perfilhos conforme aumenta-se a intensidade de pastejo. Esses mesmos autores observaram que esse limite estaria sujeito a variações inter-específicas que seriam relacionadas à incapacidade de gramíneas em reduzir o comprimento da bainha a fim de manter as folhas residuais abaixo da altura de corte/pastejo. Hernández Garay et al. (1999), trabalhando com azevém perene em condições controladas, já haviam observado situação semelhante. Considerando que nos meses que antecederam essa avaliação as condições de ambiente não foram muito diferentes da média histórica (Tabela 2), esse fato, provavelmente, mostra que pastagens de Cynodon não seriam capazes de compensar a reduzida altura de pastejo com aumentos em densidade populacional de perfilhos, indicando que pastejos mais severos deveriam ser evitados naquela época do ano (outono). Além disso, essa situação se enquadra dentro de uma condição ilustrada teoricamente por Matthew et al. (1995), onde uma alta intensidade de pastejo pode, em certas circunstâncias, restringir o perfilhamento de gramíneas. Já na $4^{\text {a }}$ avaliação os cultivares tiveram um comportamento inverso, ou seja, maiores densidades populacionais de perfilhos estiveram associadas com pastos mais altos. Esse fato deveu-se, provavelmente, à ocorrência de estruturas típicas de pastos de Cynodon onde há a formação de dezenas de perfilhos muito pequenos sobre uma haste normalmente muito lignificada, as rosetas (Foto 3). Estes perfilhos normalmente têm um período de vida muito curto (de 3 a 4 semanas) (Carnevalli e Da Silva, 1999) e acabaram por inflacionar os valores de densidade populacional mensurados. 


\subsection{Massa seca, massa de folhas e volume médio por perfilho}

Para massa seca média por perfilho foram observadas diferenças entre datas de avaliação ( $\mathrm{P}=0,0001)$ e cultivar $(\mathrm{P}=0,0341)$ (Tabela 5), além de efeito de altura $(\mathrm{P}=0,0001)$ e interação datas de avaliação x altura $(\mathrm{P}=0,0036)$ (Tabela 6). Para massa média de folhas por perfilho foram observadas diferenças entre datas de avaliação $(\mathrm{P}=0,0001)$ (Tabela 7), altura $(\mathrm{P}=0,0001)$ e interação datas de avaliação $\mathrm{x}$ altura $(\mathrm{P}=0,0063)$ (Tabela 8). Para volume médio por perfilho foram observadas diferenças entre datas de avaliação $(\mathrm{P}=0,0001)$ (Tabela 9), altura $(\mathrm{P}=0,0001)$ e interação datas de avaliação x altura ( $\mathrm{P}=0,0239)$ (Tabela 10).

A massa média por perfilho foi maior na $1^{\mathrm{a}}$ avaliação quando comparada com todas as outras, independentemente do cultivar (Tabela 5). O mesmo foi observado para massa média de folhas e volume médio por perfilho (Tabelas 7 e 9).

Tabela 5. Massa média por perfilho (mg) em pastos de Cynodon spp. durante o período experimental.

\begin{tabular}{ccccccc}
\hline & \multicolumn{5}{c}{ Cultivares } & \\
\cline { 2 - 4 } $\begin{array}{c}\text { Datas de } \\
\text { avaliação }\end{array}$ & Tifton 85 & Florakirk & Coastcross & Média & EPM \\
\hline 1 & $68,1^{\mathrm{a}}$ & $58,8^{\mathrm{ab}}$ & $49,6^{\mathrm{b}}$ & 58,3 & 4,80 \\
2 & $32,5^{\mathrm{a}}$ & $39,2^{\mathrm{a}}$ & $37,5^{\mathrm{a}}$ & 36,4 & 3,54 \\
3 & $35,1^{\mathrm{a}}$ & $40,0^{\mathrm{a}}$ & $31,0^{\mathrm{a}}$ & 35,4 & 3,47 \\
4 & $48,2^{\mathrm{a}}$ & $49,2^{\mathrm{a}}$ & $34,7^{\mathrm{a}}$ & 44,0 & 6,74 \\
\hline
\end{tabular}

Médias na mesma linha seguidas de letras semelhantes não diferem entre si ( $\mathrm{P}>0,10)$ EPM - Erro padrão da média. Data 1=15/12/98; Data 2=25/01/99; Data 3=07/04/99 e Data 4=04/07/99.

Em outubro/98 ocorreu uma elevada precipitação que superou em $80 \mathrm{~mm}$ a média dos últimos 80 anos (Tabela 1 e Figura 4). Além disso, foi realizada naquele mês uma adubação com $50 \mathrm{~kg} \mathrm{~N} \cdot \mathrm{ha}^{-1}$. Em novembro ocorreu uma drástica redução em 
precipitação, com cerca de $90 \mathrm{~mm}$ a menos de chuvas que a média dos últimos 80 anos (Tabela 1). Outros fatores de crescimento como temperatura e insolação não foram limitantes. Esse conjunto de fatores pode ter criado uma situação onde os pastos não cresceram, porém continuaram acumulando nutrientes, principalmente via fotossíntese. Esse fato poderia justificar o fato de que os perfilhos em dezembro tivessem uma massa maior quando comparados com os valores dos outros meses.

Pastos mais altos $(20 \mathrm{~cm})$ apresentaram perfilhos mais pesados que pastos mais baixos $(5 \mathrm{~cm})$, independente do período de avaliação (Tabela 6). Esse fato, juntamente com os dados de densidade populacional de perfilhos (Tabela 4), evidenciam que o mecanismo de compensação tamanho/densidade populacional descrito e amplamente citado na literatura (Grant et al., 1982; Bircham \& Hodgson, 1983; Hernández Garay et al., 1999) estava operando, uma vez que altas DPP estiveram associadas com massa média por perfilho reduzida, exceção feita à última avaliação. O mesmo padrão de resposta foi observado para massa de folhas por perfilho (Tabela 8) e volume por perfilho ( Tabela 10).

Tabela 6. Massa média por perfilho (mg) para as alturas de pasto estudadas.

\begin{tabular}{|c|c|c|c|c|c|c|}
\hline \multirow{2}{*}{$\begin{array}{l}\text { Datas de } \\
\text { avaliação }\end{array}$} & \multicolumn{4}{|c|}{ Altura de pasto $(\mathrm{cm})$} & \multirow[b]{2}{*}{ Média } & \multirow[b]{2}{*}{ EPM } \\
\hline & 5 & 10 & 15 & 20 & & \\
\hline 1 & $22,2^{\mathrm{d}}$ & $43,8^{c}$ & $68,4^{b}$ & $101,0^{\mathrm{a}}$ & 58,3 & 5,54 \\
\hline 2 & $15,2^{\mathrm{d}}$ & $31,3^{\mathrm{c}}$ & $43,7^{b}$ & $55,4^{\mathrm{ab}}$ & 36,4 & 4,08 \\
\hline 3 & $18,7^{\mathrm{d}}$ & $23,8^{\mathrm{cd}}$ & $33,7^{b c}$ & $65,3^{\mathrm{a}}$ & 35,4 & 4,01 \\
\hline 4 & $22,6^{\mathrm{c}}$ & $41,3^{a b c}$ & $49,6^{a b}$ & $62,6^{\mathrm{a}}$ & 44,0 & 7,79 \\
\hline
\end{tabular}

Médias na mesma linha seguidas de letras semelhantes não diferem entre si $(\mathrm{P}>0,10)$ EPM - Erro padrão da média. Data 1=15/12/98; Data 2=25/01/99; Data 3=07/04/99 e Data 4=04/07/99.

Esses resultados corroboram aqueles verificados para plantas de clima temperado, onde em pastos mais altos também foram verificadas as maiores massas de folhas e maior massa por perfilho (Matthew et al., 1995; Hernández Garay et al., 1999). 
Além disso, Matthew et al. (1995) já haviam observado maiores valores de volume médio por perfilho em pastos de azevém mantidos mais altos em relação a pastos mais baixos.

Tabela 7. Massa média de folhas por perfilho (mg) em pastos de Cynodon spp. durante o período experimental

\begin{tabular}{cccccc}
\hline & \multicolumn{4}{c}{ Cultivares } & \\
\cline { 2 - 4 } $\begin{array}{c}\text { Datas de } \\
\text { avaliação }\end{array}$ & Tifton 85 & Florakirk & Coastcross & Média & EPM \\
\hline 1 & $21,8^{\mathrm{a}}$ & $18,7^{\mathrm{a}}$ & $19,2^{\mathrm{a}}$ & 19,9 & 1,35 \\
\hline 2 & $13,6^{\mathrm{a}}$ & $14,8^{\mathrm{a}}$ & $15,7^{\mathrm{a}}$ & 14,7 & 1,32 \\
3 & $13,1^{\mathrm{a}}$ & $11,8^{\mathrm{ab}}$ & $10,4^{\mathrm{b}}$ & 11,8 & 2,35 \\
4 & $19,3^{\mathrm{a}}$ & $18,3^{\mathrm{a}}$ & $12,7^{\mathrm{b}}$ & 16,8 & 2,30
\end{tabular}

Médias na mesma linha seguidas de letras semelhantes não diferem entre si (P>0,10)

EPM - Erro padrão da média. Data 1=15/12/98; Data 2=25/01/99; Data 3=07/04/99 e Data 4=04/07/99.

Tabela 8. Massa média de folhas por perfilho (mg) para as alturas de pasto estudadas.

\begin{tabular}{ccccccc}
\hline & \multicolumn{5}{c}{ Altura de pasto (cm) } \\
\cline { 2 - 5 } $\begin{array}{c}\text { Datas de } \\
\text { avaliação }\end{array}$ & 5 & $10^{2}$ & $15^{2}$ & 20 & Média & EPM \\
\hline 1 & $8,7^{\mathrm{d}}$ & $17,1^{\mathrm{c}}$ & $23,4^{\mathrm{b}}$ & $30,4^{\mathrm{a}}$ & 19,9 & 1,56 \\
2 & $7,1^{\mathrm{d}}$ & $13,5^{\mathrm{c}}$ & $17,3^{\mathrm{bc}}$ & $20,9^{\mathrm{ab}}$ & 14,7 & 1,53 \\
3 & $7,7^{\mathrm{c}}$ & $9,2^{\mathrm{c}}$ & $11,8^{\mathrm{b}}$ & $18,2^{\mathrm{a}}$ & 11,8 & 0,91 \\
4 & $10,0^{\mathrm{c}}$ & $15,2^{\mathrm{bc}}$ & $20,1^{\mathrm{ab}}$ & $21,8^{\mathrm{a}}$ & 16,8 & 2,00 \\
\hline
\end{tabular}

Médias na mesma linha seguidas de letras semelhantes não diferem entre si $(\mathrm{P}>0,10)$ EPM - Erro padrão da média. Data 1=15/12/98; Data 2=25/01/99; Data 3=07/04/99 e Data 4=04/07/99. 
Tabela 9. Volume médio por perfilho $\left(\mathrm{cm}^{3}\right)$ em pastos de Cynodon spp. durante o período experimental.

\begin{tabular}{cccccc}
\hline & \multicolumn{5}{c}{ Cultivares } \\
\cline { 2 - 4 } $\begin{array}{c}\text { Datas de } \\
\text { avaliação }\end{array}$ & Tifton 85 & Florakirk & Coastcross & Média & EPM \\
\hline 1 & $0,40^{\mathrm{a}}$ & $0,34^{\mathrm{ab}}$ & $0,29^{\mathrm{b}}$ & 0,34 & 0,28 \\
2 & $0,19^{\mathrm{a}}$ & $0,23^{\mathrm{a}}$ & $0,22^{\mathrm{a}}$ & 0,21 & 0,20 \\
3 & $0,36^{\mathrm{a}}$ & $0,23^{\mathrm{a}}$ & $0,18^{\mathrm{a}}$ & 0,26 & 0,07 \\
4 & $0,28^{\mathrm{a}}$ & $0,29^{\mathrm{a}}$ & $0,20^{\mathrm{a}}$ & 0,26 & 0,04 \\
\hline
\end{tabular}

Médias na mesma linha seguidas de letras semelhantes não diferem entre si (P>0,10)

EPM - Erro padrão da média. Data 1=15/12/98; Data 2=25/01/99; Data 3=07/04/99 e Data 4=04/07/99.

Tabela 10. Volume médio por perfilho $\left(\mathrm{cm}^{3}\right)$ para as alturas de pasto estudadas.

\begin{tabular}{cccccccc}
\hline & \multicolumn{5}{c}{ Altura de pasto (cm) } \\
\cline { 2 - 5 } $\begin{array}{c}\text { Datas de } \\
\text { avaliação }\end{array}$ & 5 & $10^{2}$ & $15^{2}$ & 20 & Média & EPM \\
\hline 1 & $0,13^{\mathrm{d}}$ & $0,26^{\mathrm{c}}$ & $0,40^{\mathrm{b}}$ & $0,59^{\mathrm{a}}$ & 0,34 & 0,03 \\
2 & $0,09^{\mathrm{c}}$ & $0,18^{\mathrm{b}}$ & $0,26^{\mathrm{a}}$ & $0,32^{\mathrm{a}}$ & 0,21 & 0,02 \\
3 & $0,11^{\mathrm{b}}$ & $0,15^{\mathrm{b}}$ & $0,24^{\mathrm{b}}$ & $0,54^{\mathrm{a}}$ & 0,26 & 0,08 \\
4 & $0,13^{\mathrm{b}}$ & $0,24^{\mathrm{ab}}$ & $0,29^{\mathrm{a}}$ & $0,37^{\mathrm{a}}$ & 0,26 & 0,04
\end{tabular}

Médias na mesma linha seguidas de letras semelhantes não diferem entre si (P>0,10)

EPM - Erro padrão da média. Data 1=15/12/98; Data 2=25/01/99; Data 3=07/04/99 e Data 4=04/07/99. 


\subsection{Biomassa aérea total $\left(\mathrm{kg} \mathrm{MS} / \mathrm{m}^{2}\right)$}

Os dados referentes à biomassa aérea total são mostrados na Tabela $11 \mathrm{e}$ Figuras 8 e 9. Foram observadas diferenças entre datas de avaliação $(\mathrm{P}=0,0001)$ e cultivar ( $\mathrm{P}=0,0001)$ (Tabela 11 e Figura 8), altura $(\mathrm{P}=0,0001)$ (Tabela 11 e Figura 9) e interação cultivar x altura ( $\mathrm{P}=0,0895)$ (Tabela 11).

Tifton-85 e Florakirk apresentaram, consistentemente, maiores valores de biomassa aérea total que Coastcross, independente do mês de avaliação. Esse fato é corroborado pelos dados de massa por perfilho mostrados na Tabela 5, onde, apesar de não terem sido verificadas diferenças estatísticas, Tifton-85 e Florakirk apresentaram os maiores valores observados. Os maiores valores de biomassa foram verificados na avaliação 1, conforme ilustrado na Tabela 11. Considerando que a biomassa é o resultado da soma das massas de perfilhos individuais, os resultados mostrados também corroboram aqueles mostrados na Tabela 5, onde as maiores massas por perfilho também foram observadas durante a primeira avaliação. Além disso, houve um aumento da biomassa com o aumento da altura do pasto (Tabela 11 e Figura 9).

Estudos agronômicos têm tratado a densidade populacional de perfilhos como se ela fosse uma medida do vigor ou produtividade do pasto (Binnie \& Chestnut, 1991; Thom \& Bryant, 1993). No entanto alguns trabalhos mostraram a importância da interação entre massa de perfilhos individuais e densidade populacional de perfilhos na determinação do vigor e produtividade de pastagens (Langer, 1963; Bircham \& Hodgson, 1983). Tem-se assumido que incrementos em densidade populacional de perfilhos sejam mais importantes em situações de baixa densidade populacional (Nelson \& Zarrough, 1981; Volenec \& Nelson, 1983). Essa situação foi verificada particularmente na $3^{\text {a }}$ avaliação do presente estudo, onde o aumento da massa por perfilho entre as alturas de 5 e $10 \mathrm{~cm}$ foi de, aproximadamente, $27 \%$, enquanto que nas avaliações 1, 2 e 4 este incremento foi próximo de 100\% (Tabela 6). No entanto, a biomassa aérea total aumentou em $82 \%$ (Tabela 10), mostrando que, naquela avaliação, o incremento em biomassa entre pastos de 5 e $10 \mathrm{~cm}$ foi grandemente influenciado pela DPP, que aumentou em 56\% (Tabela 4). 
Tabela 11. Biomassa aérea total $\left(\mathrm{kg} \mathrm{MS} / \mathrm{m}^{2}\right)$ em pastos de Cynodon spp. mantidos em quatro alturas de relvado.

\begin{tabular}{|c|c|c|c|c|c|}
\hline \multirow{2}{*}{$\begin{array}{l}\text { Altura de } \\
\text { pasto }(\mathrm{cm})\end{array}$} & \multicolumn{3}{|c|}{ Cultivares } & \multirow[b]{2}{*}{ Média } & \multirow[b]{2}{*}{ EPM* } \\
\hline & Tifton-85 & Florakirk & Coastcross & & \\
\hline \multicolumn{6}{|c|}{ Avaliação 1 (15/12/98): } \\
\hline 5 & $0,373^{\mathrm{aD}}$ & $0,316^{\mathrm{aC}}$ & $0,276^{\mathrm{aC}}$ & $0,322^{(\mathrm{D})}$ & 0,028 \\
\hline 10 & $0,507^{\mathrm{abC}}$ & $0,555^{\mathrm{aB}}$ & $0,391^{\mathrm{bC}}$ & $0,484^{(\mathrm{C})}$ & 0,026 \\
\hline 15 & $0,680^{\mathrm{aB}}$ & $0,602^{a b A B}$ & $0,505^{\mathrm{bAB}}$ & $0,596^{(\mathrm{B})}$ & 0,026 \\
\hline 20 & $0,843^{\mathrm{aA}}$ & 0,700 bA & $0,598^{\mathrm{bA}}$ & $0,713^{(\mathrm{A})}$ & 0,026 \\
\hline Média & $0,601^{(a)}$ & $0,543^{(a)}$ & $0,442^{(b)}$ & & \\
\hline $\mathrm{EPM}^{*}$ & 0,023 & 0,023 & 0,024 & & \\
\hline \multicolumn{6}{|c|}{ Avaliação 2 (25/01/99): } \\
\hline 5 & $0,202^{\mathrm{aD}}$ & $0,192^{\mathrm{aC}}$ & $0,165^{\mathrm{aC}}$ & $0,186^{(\mathrm{D})}$ & 0,018 \\
\hline 10 & $0,368^{\mathrm{abC}}$ & $0,413^{\mathrm{aB}}$ & $0,325^{\mathrm{bB}}$ & $0,369^{(\mathrm{C})}$ & 0,017 \\
\hline 15 & $0,476^{\mathrm{aB}}$ & $0,439^{\mathrm{abB}}$ & $0,375^{\mathrm{bB}}$ & $0,430^{(\mathrm{B})}$ & 0,017 \\
\hline 20 & $0,663^{\mathrm{aA}}$ & $0,628^{\mathrm{abA}}$ & $0,548^{\mathrm{bA}}$ & $0,613^{(\mathrm{A})}$ & 0,017 \\
\hline Média & $0,427^{\text {(a) }}$ & $0,418^{\text {(a) }}$ & $0,353^{(b)}$ & & \\
\hline $\mathrm{EPM}^{*}$ & 0,014 & 0,014 & 0,015 & & \\
\hline \multicolumn{6}{|c|}{ Avaliação 3 (07/04/99): } \\
\hline 5 & $0,213^{\mathrm{aD}}$ & $0,207^{\mathrm{aD}}$ & $0,209^{\mathrm{aC}}$ & $0,210^{(\mathrm{D})}$ & 0,019 \\
\hline 10 & $0,421^{\mathrm{aC}}$ & $0,408^{a b C}$ & $0,319^{\mathrm{bB}}$ & $0,382^{(\mathrm{C})}$ & 0,018 \\
\hline 15 & $0,534^{\mathrm{aB}}$ & $0,498^{\mathrm{bB}}$ & $0,384^{\mathrm{cB}}$ & $0,472^{(B)}$ & 0,018 \\
\hline 20 & $0,751^{\mathrm{aA}}$ & $0,682^{\text {aA }}$ & $0,571^{\mathrm{bA}}$ & $0,668^{(\mathrm{A})}$ & 0,018 \\
\hline Média & $0,480^{\text {(a) }}$ & $0,449^{\text {(a) }}$ & $0,370^{(b)}$ & & \\
\hline $\mathrm{EPM}^{*}$ & 0,015 & 0,015 & 0,016 & & \\
\hline \multicolumn{6}{|c|}{ Avaliação 4 (04/07/99): } \\
\hline 5 & $0,370^{\mathrm{aC}}$ & $0,309^{\mathrm{aC}}$ & $0,259^{\mathrm{aC}}$ & $0,313^{(\mathrm{D})}$ & 0,027 \\
\hline 10 & $0,458^{\mathrm{aC}}$ & $0,475^{\mathrm{aB}}$ & $0,354^{\mathrm{aC}}$ & $0,429^{(\mathrm{C})}$ & 0,025 \\
\hline 15 & $0,616^{\mathrm{aB}}$ & $0,588^{\mathrm{abA}}$ & $0,476^{\mathrm{bB}}$ & $0,560^{(\mathrm{B})}$ & 0,025 \\
\hline 20 & $0,792^{\mathrm{aA}}$ & $0,623^{\mathrm{bA}}$ & $0,720^{\mathrm{abA}}$ & $0,712^{(\mathrm{A})}$ & 0,025 \\
\hline Média & $0,599^{\text {(a) }}$ & $0,499^{(a b)}$ & $0,452^{(b)}$ & & \\
\hline $\mathrm{EPM}^{*}$ & 0,022 & 0,022 & 0,023 & & \\
\hline
\end{tabular}

*EPM - Erro padrão da média. Médias na mesma linha (minúsculas) e na mesma coluna (maiúsculas) seguidas de letras semelhantes não diferem entre si $(\mathrm{P}>0,10)$. 


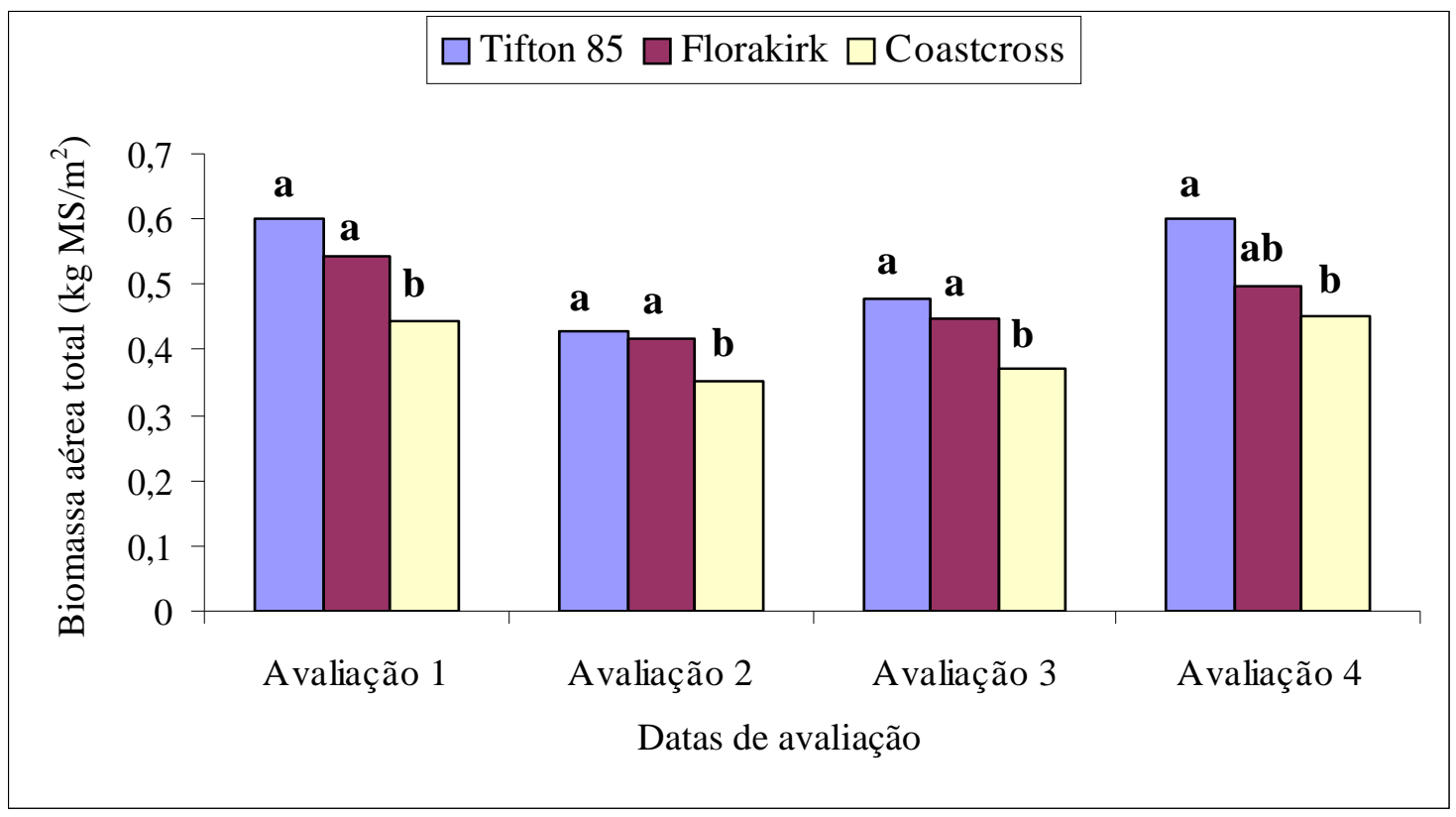

Figura 8 - Biomassa área total $\left(\mathrm{kg} \mathrm{MS} / \mathrm{m}^{2}\right)$ em pastos de Cynodon spp. durante o período experimental. Data 1=15/12/98; Data 2=25/01/99; Data 3=07/04/99 e Data $4=04 / 07 / 99$.

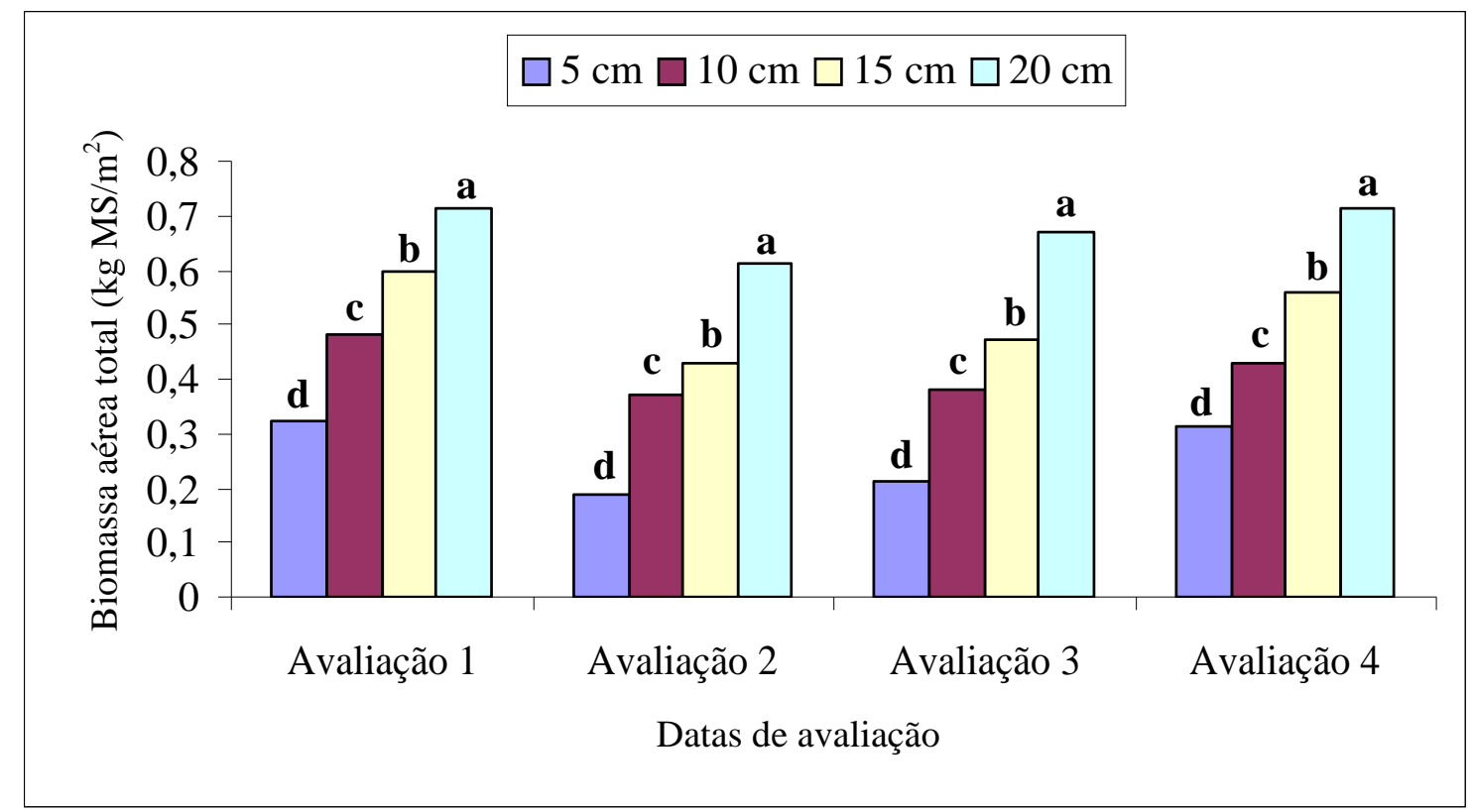

Figura 9 - Biomassa aérea total $\left(\mathrm{kg} \mathrm{MS} / \mathrm{m}^{2}\right)$ em pastos de Cynodon spp. mantidos em diferentes alturas durante o período experimental. Data 1=15/12/98; Data $2=25 / 01 / 99$; Data $3=07 / 04 / 99$ e Data $4=04 / 07 / 99$. 
Outras três situações semelhantes onde aumentos em DPP foram determinantes da produção de biomassa aérea total também foram verificadas. O cultivar Florakirk, na $2^{\underline{a}}$ avaliação, apresentou um decréscimo na massa média por perfilho entre as alturas de 15 e $20 \mathrm{~cm}$. No entanto, houve um incremento de $43 \%$ na biomassa aérea total, resultado de um aumento de $50 \%$ em DPP. Na $4^{\text {a }}$ avaliação o cultivar Tifton-85, entre as alturas de 10 e $15 \mathrm{~cm}$, apresentou um incremento de apenas $2 \%$ na massa média por perfilho, sendo o aumento de $35 \%$ em biomassa aérea total o resultado do aumento de $44 \%$ em DPP. Ainda na 4 ${ }^{\underline{a}}$ avaliação, o cultivar Coastcross, entre as alturas de 15 e $20 \mathrm{~cm}$, aumentou sua massa média por perfilho em 3\%, enquanto que a biomassa aérea total aumentou em 51\%, resultado esse só explicável pelo aumento de 47\% em DPP. Já para as demais situações, de uma maneira geral, os fatores determinantes do aumento na biomassa aérea estiveram relacionados com aumentos em massa por perfilho e, em algumas situações, aumentos em ambos, DPP e massa por perfilho, já que nessas avaliações ocorreu uma redução na DPP conforme a altura do pasto aumentou. A relação funcional entre massa por perfilho e biomassa aérea total revelou uma correlação simples positiva $(>0,90)$ entre essas duas variáveis (Tabela 12 e Figura 10$)$. Volenec \& Nelson (1983) reconheceram que em algumas circunstâncias a massa por perfilho seria mais importante na determinação da produtividade do pasto que o número de perfilhos. Os dados obtidos neste estudo demonstram a importância da massa do perfilho como determinante principal, no caso de pastagens de Cynodon spp., para a produção de biomassa aérea total (Tabela 12 e Figura 10). Como pode ser observado, todas as regressões entre massa por perfilho e biomassa foram significativas e apresentaram um $\mathrm{R}^{2}$ sempre superior a $85 \%$. Também suportado pelos resultados de massa média por perfilho (Tabela 6), as maiores massas de forragem foram encontradas em pastos mantidos altos $(20 \mathrm{~cm})$, enquanto que pastos de $5 \mathrm{~cm}$ apresentaram os menores valores de biomassa aérea total. 
Tabela 12. Coeficientes angulares, coeficientes de determinação e significância para as regressões entre massa por perfilho e biomassa aérea total em pastos de Cynodon spp. durante o período experimental.

\begin{tabular}{cccccc}
\hline & \multicolumn{5}{c}{ Parâmetros } \\
\cline { 2 - 6 } $\begin{array}{c}\text { Datas de } \\
\text { avaliação }\end{array}$ & $\beta_{0}$ & $\beta_{1}$ & Modelo & $\mathrm{R}^{2}$ & $\mathrm{P}_{\text {modelo }}$ \\
\hline 1 & 0,2435 & 0,0048 & $\mathrm{Y}=0,2435+0,0048 \mathrm{x}$ & 0,9702 & 0,0150 \\
2 & 0,0329 & 0,0100 & $\mathrm{Y}=0,0329+0,0101 \mathrm{x}$ & 0,9702 & 0,0150 \\
3 & 0,1285 & 0,0086 & $\mathrm{Y}=0,1285+0,0009 \mathrm{x}$ & 0,8896 & 0,0568 \\
4 & 0,0608 & 0,0101 & $\mathrm{Y}=0,0608+0,0101 \mathrm{x}$ & 0,9626 & 0,0189
\end{tabular}

Data 1=15/12/98; Data 2=25/01/99; Data 3=07/04/99 e Data 4=04/07/99.

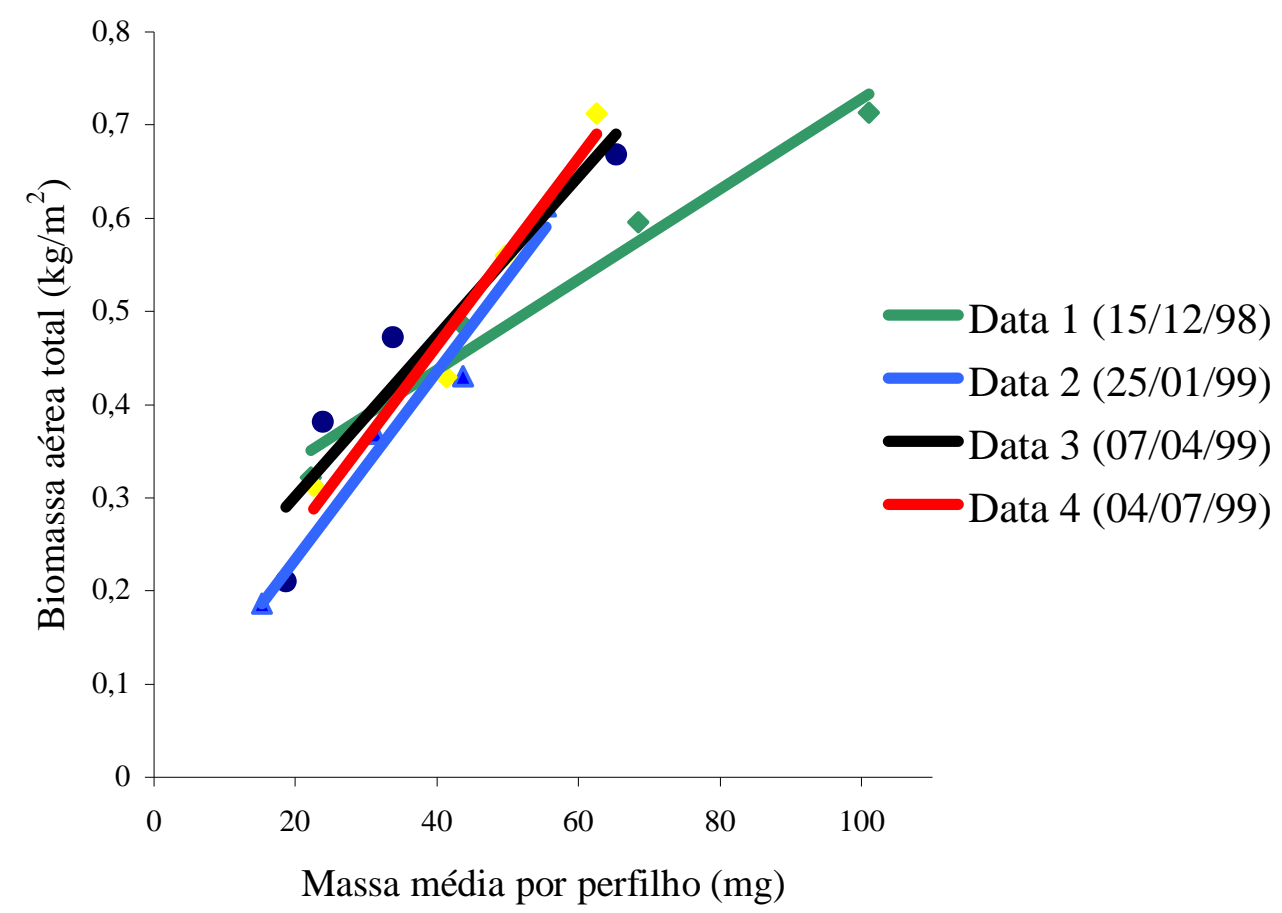

Figura 10 - Relação entre massa por perfilho e biomassa aérea total em pastos de Cynodon spp. durante o período experimental. 


\section{4 Área foliar média por perfilho e índice de área foliar do pasto (IAF)}

Para área foliar média por perfilho foram encontradas diferenças entre datas de avaliação $(\mathrm{P}=0,0002)$, cultivar $(\mathrm{P}=0,0132)$ e interação datas de avaliação $\mathrm{x}$ cultivar $(\mathrm{P}=0,0319)$ (Tabela 13), além do efeito de altura $(\mathrm{P}=0,0001)$ (Tabela 14). Para índice de área foliar foram verificados efeitos de datas de avaliação $(\mathrm{P}=0,0465)$, cultivar $(\mathrm{P}=0,0010)$, altura $(\mathrm{P}=0,0001)$ e interações entre datas de avaliação $\mathrm{x}$ altura $(\mathrm{P}=0,0328)$ e cultivar x altura $(\mathrm{P}=0,0272)$ (Tabela 15 e Figuras 11 e 12).

Os maiores valores de área foliar média por perfilho foram verificados na $1^{\mathrm{a}} \mathrm{e}$ $4^{\underline{a}}$ avaliações (Tabela 13). Além disso, o cultivar Coastcross apresentou valores menores que os cultivares Tifton-85 e Florakirk (Tabela 13) na $3^{\underline{a}}$ e $4^{\underline{a}}$ avaliações. Esse fato pode ser explicado pelo intenso florescimento ocorrido no cultivar Coastcross durante as duas últimas avaliações, particularmente, nas maiores alturas de pasto, que, associado ao hábito altamente seletivo dos ovinos em pastejo, resultou em área foliar reduzida por perfilho.

Tabela 13. Área foliar média por perfilho $\left(\mathrm{cm}^{2} /\right.$ perfilho) em pastos de Cynodon spp. durante o período experimental.

\begin{tabular}{cccccc}
\hline & \multicolumn{5}{c}{ Cultivares } \\
\cline { 2 - 4 } $\begin{array}{c}\text { Datas de } \\
\text { avaliação }\end{array}$ & Tifton 85 & Florakirk & Coastcross & Média & EPM \\
\hline 1 & $3,00^{\mathrm{a}}$ & $2,58^{\mathrm{a}}$ & $2,54^{\mathrm{a}}$ & 2,71 & 0,24 \\
2 & $2,06^{\mathrm{a}}$ & $2,62^{\mathrm{a}}$ & $2,36^{\mathrm{a}}$ & 2,35 & 0,22 \\
3 & $2,09^{\mathrm{a}}$ & $2,16^{\mathrm{a}}$ & $1,59^{\mathrm{b}}$ & 1,95 & 0,13 \\
4 & $2,67^{\mathrm{a}}$ & $3,15^{\mathrm{a}}$ & $1,97^{\mathrm{b}}$ & 2,60 & 0,22 \\
\hline
\end{tabular}

Médias na mesma linha seguidas de letras semelhantes não diferem entre si ( $\mathrm{P}>0,10)$

EPM - Erro padrão da média. Data 1=15/12/98; Data 2=25/01/99; Data 3=07/04/99 e Data 4=04/07/99. 
Conforme seria esperado, pastos mantidos mais altos apresentaram área de lâminas foliares maior que pastos mantidos mais baixos (Tabela 14). Matthew et al. (1999) mostraram que o índice de área foliar é o resultado da interação entre três fatores distintos: densidade populacional de perfilhos, número de folhas vivas por perfilho e a área de cada folha. $\mathrm{O}$ número de folhas vivas por perfilho é um valor normalmente constante para uma dada espécie (Davies, 1977; Yang et al., 1998; Carnevalli \& Da Silva, 1999). Já a área foliar é determinada basicamente pelo comprimento da folha que, por sua vez, é controlado pela intensidade de desfolha. Dessa forma, a DPP seria o componente do IAF que permitiria a maior flexibilidade de ajuste por parte da planta a diferentes regimes de desfolha, razão pela qual o IAF seria otimizado em pastos mantidos baixos através de uma alta densidade populacional de perfilhos pequenos. Já para pastos mantidos altos essa otimização ocorreria através de uma menor densidade populacional de perfilhos grandes (Matthew et al., 1999).

Tabela 14. Área foliar média por perfilho $\left(\mathrm{cm}^{2} /\right.$ perfilho) para as alturas de pasto estudadas.

\begin{tabular}{|c|c|c|c|c|c|c|}
\hline \multirow[b]{2}{*}{$\begin{array}{l}\text { Datas de } \\
\text { avaliação }\end{array}$} & \multicolumn{4}{|c|}{ Altura de pasto $(\mathrm{cm})$} & \multirow[b]{2}{*}{ Média } & \multirow[b]{2}{*}{ EPM } \\
\hline & 5 & 10 & 15 & 20 & & \\
\hline 1 & $1,18^{c}$ & $2,43^{b}$ & $3,13^{\mathrm{b}}$ & $4,08^{\mathrm{a}}$ & 2,71 & 0,28 \\
\hline 2 & $1,27^{\mathrm{c}}$ & $2,17^{b}$ & $2,64^{\mathrm{ab}}$ & $3,31^{\text {a }}$ & 2,35 & 0,26 \\
\hline 3 & $1,32^{\mathrm{c}}$ & $1,58^{\mathrm{c}}$ & $2,03^{b}$ & $2,86^{a}$ & 1,95 & 0,15 \\
\hline 4 & $1,64^{\mathrm{c}}$ & $2,32 \mathrm{bc}$ & $3,02^{a b}$ & $3,39^{\mathrm{a}}$ & 2,60 & 0,26 \\
\hline
\end{tabular}

O valores de IAF encontrados no presente ensaio variaram entre 1,25 e 4,77 (Tabela 15). Fagundes (1999) trabalhando na mesma área, porém com técnica diferente, obteve valores de IAF que variaram entre 0,21 e 3,87. Já Gomide (1996) observou 
valores mínimo e máximo de IAF de 1,68 e 5,85 para Tifton-85 e 1,19 e 5,89 para Florakirk, quando estes foram avaliados aos 14 e 42 dias de crescimento, respectivamente. Segundo Brougham (1957) e Mott \& Popenoe (1977), os valores de IAF ótimo variam de 2 a 3 até valores maiores que 15 conforme a espécie, sendo que existem grandes diferenças entre cultivares dentro de uma mesma espécie, o que suporta os resultados obtidos neste trabalho.

Tifton-85 e Florakirk apresentaram, de maneira geral, valores de IAF mais elevados que Coastcross (Tabela 15 e Figura 11). Segundo Cooper (1983) e Madakadze et al. (1998), as diferenças entre cultivares refletem a história evolutiva da população, ou seja, através de mecanismos adaptativos ou de cruzamentos naturais intra-genéricos e intra-específicos as plantas poderiam desenvolver valores diferentes de IAF para uma dada condição. Além disso, aqueles mesmos autores argumentaram que a variação em IAF entre cultivares poderia ser oriunda de programas deliberados de melhoramento e seleção. Os maiores valores de IAF foram observados por ocasião da $4^{\mathrm{a}}$ avaliação (Tabela 15). Esse fato pode ser explicado pelos maiores valores de DPP verificados naquela época. Interessante observar que nas avaliações 1, 2 e 3 os valores de IAF praticamente não variaram, o que ilustra uma situação onde a DPP opera em sentido oposto àquele da área foliar média por perfilho. Ou seja, pastos mantidos mais altos apresentaram um valor de área foliar média por perfilho maior que aqueles mantidos mais baixos (Tabela 15 e Figura 12). No entanto, o IAF foi otimizado em cada condição de pasto com acréscimos ou decréscimos em DPP (Tabela 4). 
Tabela 15. Índice de área foliar (IAF) em pastos de Cynodon spp. mantidos em quatro alturas do relvado

\begin{tabular}{|c|c|c|c|c|c|}
\hline \multirow{2}{*}{$\begin{array}{l}\text { Altura de } \\
\text { pasto }(\mathrm{cm})\end{array}$} & \multicolumn{3}{|c|}{ Cultivares } & \multirow[b]{2}{*}{ Média } & \multirow[b]{2}{*}{ EPM* } \\
\hline & Tifton-85 & Florakirk & Coastcross & & \\
\hline \multicolumn{6}{|c|}{ Avaliação 1 (15/12/98): } \\
\hline 5 & $1,95^{\mathrm{aB}}$ & $1,42^{\mathrm{aB}}$ & $1,75^{\mathrm{aA}}$ & $1,71^{(\mathrm{B})}$ & 0,31 \\
\hline 10 & $2,55^{\mathrm{aAB}}$ & $3,19^{\mathrm{aA}}$ & $2,43^{\mathrm{aA}}$ & $2,72^{(\mathrm{A})}$ & 0,29 \\
\hline 15 & $3,52^{\mathrm{aA}}$ & $2,42^{\mathrm{aAB}}$ & $2,63^{\mathrm{aA}}$ & $2,86^{(\mathrm{A})}$ & 0,29 \\
\hline 20 & $3,64^{\mathrm{aA}}$ & $2,56^{\mathrm{aAB}}$ & $2,55^{\mathrm{aA}}$ & $2,92^{(\mathrm{A})}$ & 0,29 \\
\hline Média & $2,91^{\text {(a) }}$ & $2,40^{(a)}$ & $2,34^{(a)}$ & & \\
\hline $\mathrm{EPM}^{*}$ & 0,25 & 0,25 & 0,27 & & \\
\hline \multicolumn{6}{|c|}{ Avaliação 2 (25/01/99): } \\
\hline 5 & $1,90^{\mathrm{aC}}$ & $1,47 \quad \mathrm{aD}$ & $1,39^{\mathrm{aC}}$ & $1,59^{(\mathrm{C})}$ & 0,16 \\
\hline 10 & 2,49 bBC & 3,16 aBC & $2,16^{\mathrm{bB}}$ & $2,60^{(\mathrm{B})}$ & 0,15 \\
\hline 15 & $2,75^{\mathrm{aAB}}$ & $2,74 \quad \mathrm{aB}$ & $2,32^{\mathrm{aB}}$ & $2,60^{(\mathrm{B})}$ & 0,15 \\
\hline 20 & $4,16^{\mathrm{aA}}$ & 3,93 aA & $3,16^{\mathrm{bA}}$ & $3,75^{(\mathrm{A})}$ & 0,15 \\
\hline Média & $2,82^{(a)}$ & $2,82^{(a)}$ & $2,26^{(b)}$ & & \\
\hline $\mathrm{EPM}^{*}$ & 0,13 & 0,13 & 0,14 & & \\
\hline \multicolumn{6}{|c|}{ Avaliação 3 (07/04/99): } \\
\hline 5 & $1,46^{\mathrm{aC}}$ & $1,61^{\mathrm{aC}}$ & $1,25^{\mathrm{aB}}$ & $1,44^{(\mathrm{C})}$ & 0,22 \\
\hline 10 & $2,47^{\mathrm{abB}}$ & $3,27^{\mathrm{aA}}$ & $2,24^{\mathrm{bA}}$ & $2,66^{(\mathrm{B})}$ & 0,20 \\
\hline 15 & $3,46^{\mathrm{aA}}$ & $3,47^{\text {aA }}$ & 1,99 bB & $2,97^{(\mathrm{AB})}$ & 0,20 \\
\hline 20 & $4,26^{\mathrm{aA}}$ & 2,48 bB & 2,82 bA & $3,17^{(\mathrm{A})}$ & 0,20 \\
\hline Média & $2,91^{\text {(a) }}$ & $2,70^{(a)}$ & $2,07^{(b)}$ & & \\
\hline $\mathrm{EPM}^{*}$ & 0,18 & 0,18 & 0,18 & & \\
\hline \multicolumn{6}{|c|}{ Avaliação 4 (04/07/99): } \\
\hline 5 & $2,50^{\mathrm{aC}}$ & $2,20^{\mathrm{aB}}$ & $2,15^{\mathrm{aB}}$ & $2,28^{(\mathrm{B})}$ & 0,34 \\
\hline 10 & $2,90^{\mathrm{aBC}}$ & $2,99^{\mathrm{aAB}}$ & $2,08^{\mathrm{aB}}$ & $2,66^{(B)}$ & 0,31 \\
\hline 15 & $4,48^{\mathrm{aA}}$ & $4,21^{\mathrm{aA}}$ & $2,04^{\mathrm{bB}}$ & $3,58^{(\mathrm{A})}$ & 0,31 \\
\hline 20 & $3,84^{\mathrm{aAB}}$ & $3,87^{\mathrm{aA}}$ & $4,77^{\mathrm{aA}}$ & $4,16^{(\mathrm{A})}$ & 0,31 \\
\hline Média & $3,43^{(a)}$ & $3,32^{(a b)}$ & $2,76^{(b)}$ & & \\
\hline $\mathrm{EPM}^{*}$ & 0,27 & 0,27 & 0,29 & & \\
\hline
\end{tabular}




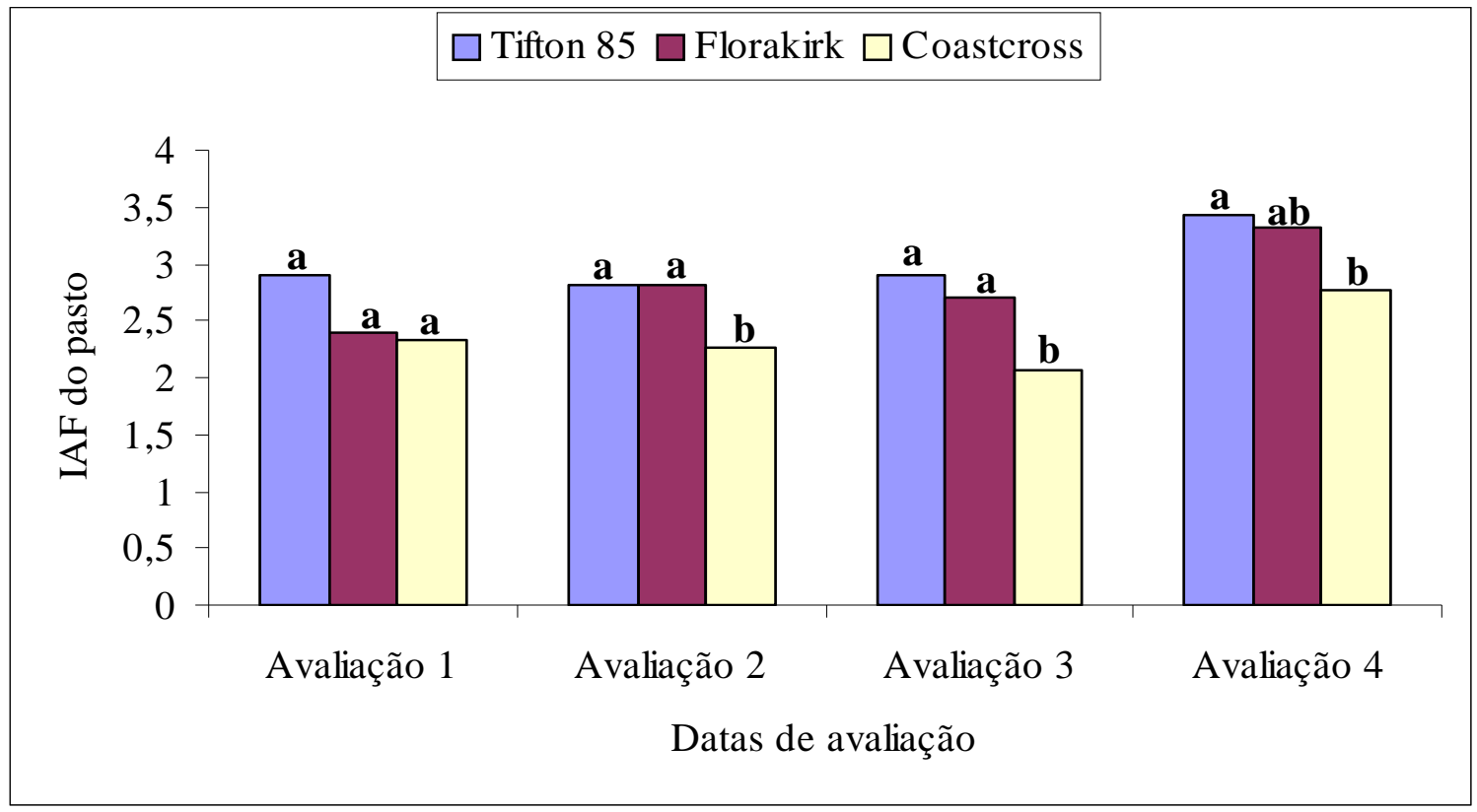

Figura 11 - Valores de IAF em pastos de Cynodon spp. durante o período experimental. Data 1=15/12/98; Data 2=25/01/99; Data 3=07/04/99 e Data 4=04/07/99.

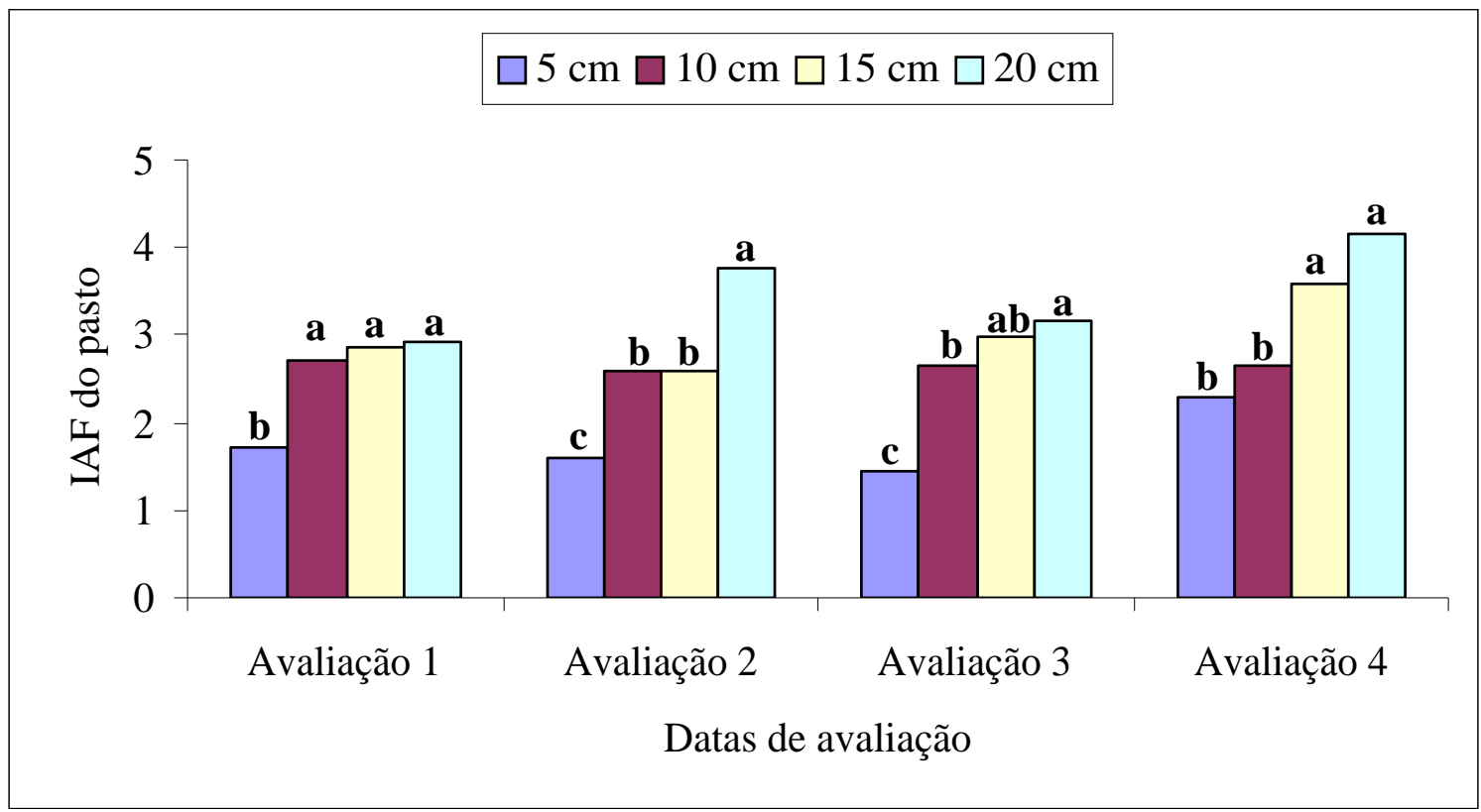

Figura 12 - Valores de IAF em pastos de Cynodon spp. mantidos em diferentes alturas durante o período experimental. Data 1=15/12/98; Data 2=25/01/99; Data $3=07 / 04 / 99$ e Data 4=04/07/99. 


\subsection{Relação folha:haste e razão área foliar:volume por perfilho (R)}

Para a relação folha:haste por perfilho foram observadas diferenças entre datas de avaliação $(\mathrm{P}=0,0016)$ e cultivar $(\mathrm{P}=0,0016)$ (Tabela 16), além de um efeito de altura do pasto $(\mathrm{P}=0,0011)$ (Tabela 17). Já para a razão área foliar:volume por perfilho foram observadas diferenças entre datas de avaliação $(\mathrm{P}=0,0004)$ e cultivar $(\mathrm{P}=0,0881)$ (Tabela 18).

As maiores relações folha:haste por perfilho foram obtidas na $2^{\underline{a}}$ e $4^{\underline{a}}$ avaliações (Tabela 16), o mesmo ocorrendo para a razão área foliar:volume (R) (Tabela 18). Além disso, de uma maneira geral, Tifton-85 e Coastcross apresentaram uma relação folha:haste por perfilho maior que Florakirk (Tabela 16). Já o valor de R praticamente não diferiu entre cultivares, exceção feita à $3^{\underline{a}}$ avaliação, onde Florakirk apresentou maiores valores que Tifton-85 e Coastcross (Tabela 18). A diferença na relação folha:haste por perfilho entre os cultivares pode ser creditada às diferenças morfológicas existentes entre os mesmos, caracterizadas por manifestações particulares de seus potenciais genéticos expressas na forma de diâmetros diferentes para hastes e variações na massa do limbo foliar.

Tabela 16. Relação folha:haste por perfilho em pastos de Cynodon spp. durante o período experimental.

\begin{tabular}{cccccc}
\hline & \multicolumn{5}{c}{ Cultivares } \\
\cline { 2 - 4 } $\begin{array}{c}\text { Datas de } \\
\text { avaliação }\end{array}$ & Tifton 85 & Florakirk & Coastcross & Média & EPM \\
\hline 1 & $0,64^{\mathrm{ab}}$ & $0,57^{\mathrm{b}}$ & $0,78^{\mathrm{a}}$ & 0,66 & 0,58 \\
2 & $0,87^{\mathrm{a}}$ & $0,69^{\mathrm{b}}$ & $0,86^{\mathrm{a}}$ & 0,81 & 0,53 \\
3 & $0,72^{\mathrm{a}}$ & $0,60^{\mathrm{a}}$ & $0,65^{\mathrm{a}}$ & 0,66 & 0,58 \\
4 & $0,96^{\mathrm{a}}$ & $0,65^{\mathrm{b}}$ & $0,80^{\mathrm{ab}}$ & 0,80 & 0,11
\end{tabular}

Médias na mesma linha seguidas de letras semelhantes não diferem entre si $(\mathrm{P}>0,10)$ EPM - Erro padrão da média. Data 1=15/12/98; Data 2=25/01/99; Data 3=07/04/99 e Data 4=04/07/99. 
Além disso, conforme aumentou-se a altura de pasto houve uma diminuição da relação folha:haste por perfilho (Tabela 17). Por outro lado, o valor de $\mathrm{R}$ não foi afetado pela altura do relvado (Tabela 19).

Tabela 17. Relação folha:haste por perfilho para as alturas de pasto estudadas.

\begin{tabular}{ccccccc}
\hline & \multicolumn{5}{c}{ Altura de pasto (cm) } \\
\cline { 2 - 5 } $\begin{array}{c}\text { Datas de } \\
\text { avaliação }\end{array}$ & 5 & $10^{2}$ & $15^{2}$ & 20 & Média & EPM \\
\hline 1 & $0,72^{\mathrm{ab}}$ & $0,76^{\mathrm{a}}$ & $0,59^{\mathrm{b}}$ & $0,57^{\mathrm{b}}$ & 0,66 & 0,07 \\
2 & $0,94^{\mathrm{a}}$ & $0,90^{\mathrm{a}}$ & $0,70^{\mathrm{b}}$ & $0,69^{\mathrm{b}}$ & 0,81 & 0,06 \\
3 & $0,78^{\mathrm{a}}$ & $0,75^{\mathrm{a}}$ & $0,64^{\mathrm{a}}$ & $0,46^{\mathrm{b}}$ & 0,66 & 0,07 \\
4 & $0,91^{\mathrm{a}}$ & $0,72^{\mathrm{a}}$ & $0,88^{\mathrm{a}}$ & $0,70^{\mathrm{a}}$ & 0,80 & 0,12 \\
\hline
\end{tabular}

Médias na mesma linha seguidas de letras semelhantes não diferem entre si (P>0,10) EPM - Erro padrão da média. Data 1=15/12/98; Data 2=25/01/99; Data 3=07/04/99 e Data 4=04/07/99.

Tabela 18. Razão área foliar:volume por perfilho (R) em pastos de Cynodon spp. durante o período experimental.

\begin{tabular}{|c|c|c|c|c|c|}
\hline \multirow{2}{*}{$\begin{array}{l}\text { Datas de } \\
\text { avaliação }\end{array}$} & \multicolumn{3}{|c|}{ Cultivares } & \multirow[b]{2}{*}{ Média } & \multirow[b]{2}{*}{ EPM } \\
\hline & Tifton 85 & Florakirk & Coastcross & & \\
\hline 1 & $14,3^{\mathrm{a}}$ & $12,4^{\mathrm{a}}$ & $14,4^{\mathrm{a}}$ & 13,7 & 1,65 \\
\hline 2 & $17,4^{\mathrm{a}}$ & $19,1^{\mathrm{a}}$ & $16,4^{\mathrm{a}}$ & 17,6 & 1,68 \\
\hline 3 & $13,1^{\mathrm{b}}$ & $16,1^{\mathrm{a}}$ & $12,1^{b}$ & 13,8 & 1,02 \\
\hline 4 & $17,1^{\mathrm{ab}}$ & $19,9^{\mathrm{a}}$ & $14,9^{\mathrm{b}}$ & 17.3 & 1,52 \\
\hline
\end{tabular}

Médias na mesma linha seguidas de letras semelhantes não diferem entre si ( $\mathrm{P}>0,10)$ EPM - Erro padrão da média. Data 1=15/12/98; Data 2=25/01/99; Data 3=07/04/99 e Data 4=04/07/99. 
Tabela 19. Razão área foliar:volume por perfilho $(\mathrm{R})$ para as alturas de pasto estudadas.

\begin{tabular}{ccccccc}
\hline \multicolumn{7}{c}{ Altura de pasto (cm) } \\
\hline $\begin{array}{c}\text { Datas de } \\
\text { avaliação }\end{array}$ & 5 & 10 & $15^{2}$ & 20 & Média & EPM \\
\hline 1 & $10,1^{\mathrm{a}}$ & $15,4^{\mathrm{a}}$ & $14,5^{\mathrm{a}}$ & $14,8^{\mathrm{a}}$ & 13,7 & 1,91 \\
2 & $16,5^{\mathrm{a}}$ & $18,3^{\mathrm{a}}$ & $16,8^{\mathrm{a}}$ & $18,9^{\mathrm{a}}$ & 17,6 & 1,95 \\
3 & $13,7^{\mathrm{a}}$ & $14,4^{\mathrm{a}}$ & $14,5^{\mathrm{a}}$ & $12,6^{\mathrm{a}}$ & 13,8 & 1,18 \\
4 & $16,3^{\mathrm{a}}$ & $15,9^{\mathrm{a}}$ & $18,9^{\mathrm{a}}$ & $18,1^{\mathrm{a}}$ & 17,3 & 1,75 \\
\hline
\end{tabular}

Médias na mesma linha seguidas de letras semelhantes não diferem entre si (P>0,10)

EPM - Erro padrão da média. Data 1=15/12/98; Data 2=25/01/99; Data 3=07/04/99 e Data 4=04/07/99.

A razão entre área foliar e volume por perfilho $(\mathrm{R})$ foi proposta por Sackville Hamilton et al. (1995). Em seu cálculo a área foliar é elevada a potência de 3/2 a fim de tornar seu valor adimensional. Segundo Hernández Garay et al. (1999), avaliações da relação folha:haste por perfilho são impróprias para efeito de cálculos da compensação tamanho/densidade populacional de perfilhos uma vez que folha e haste são componentes da planta que possuem dimensões diferentes e a relação folha:haste por perfilho não leva essas diferenças em consideração (cálculo baseado numa mesma unidade - kg). Dessa forma, aumentos em altura do pasto quase sempre conduzem a uma redução concomitante na relação folha:haste por perfilho pelo fato de que para suportar o peso de um órgão (no caso as folhas), o diâmetro das estruturas de suporte (no caso as hastes) altera-se em proporção direta à força requerida para suportá-lo e não isometricamente com o seu peso (McMahon, 1973; McMahon \& Kronauer, 1976; Niklas, 1994). No presente experimento, o valor de $\mathrm{R}$ variou pouco entre as alturas de pasto estudadas para uma determinada data de avaliação, sendo que a média entre as datas de avaliação variou de 13,7 a 17,6 (Tabela 19). A pequena variação em R significa que conforme o pasto aumentou em altura, perfilhos individuais tiveram um crescimento praticamente isométrico, ou seja, não mudaram sua forma, ocorrendo um aumento proporcional no tamanho de folhas e hastes, apesar da redução da relação folha:haste por 
perfilho calculada com base em massa apenas. Hernández Garay et al. (1999) observaram valores de $\mathrm{R}$ próximos de 50 para azevém perene, sendo que este cresceu à medida que a altura de desfolha era aumentada, indicando que em azevém ocorrem modificações na forma do perfilho que correspondem a um aumento maior de área foliar em relação ao comprimento da haste à medida que as plantas aumentam em tamanho.

Segundo Matthew et al. (1999), variações inter-específicas em R poderiam ter algumas implicações ecológicas. Segundo esses autores, plantas com valores maiores de $\mathrm{R}$ podem ter uma maior habilidade competitiva (tolerância ao pastejo) enquanto que plantas com valores menores de $\mathrm{R}$ poderiam ser mais resistentes a estresses, pois uma menor razão área foliar:volume seria uma forma da planta evitar perda de água, por exemplo. $\mathrm{O}$ menor valor de $\mathrm{R}$ obtido neste estudo, relativamente àquele encontrado na literatura para azevém perene, pode estar associado com um padrão de integração clonal existente entre perfilhos de Cynodon que serviria para otimizar o IAF do pasto e gerar maior competitividade a essa planta, de caráter reconhecidamente agressivo e colonizador. Matthew et al. (1995) mostraram que o valor de R em alfafa (forrageira com forte integração entre plantas, já que são geradas numa mesma coroa) é maior quando o seu cálculo é baseado na planta toda ao invés de brotos individuais segundo um fator de $\mathrm{n}^{1 / 2}$, onde $\mathrm{n}$ é o número de brotos por coroa.

As tabelas 20 e 21 mostram valores de R assumindo-se uma integração clonal hipotética entre 4 perfilhos de Cynodon. Observa-se que o valor de $\mathrm{R}$ dobrou em todas as situações, aproximando-se, em alguns casos, aos valores obtidos por Hernández Garay et al. (1999) para perfilhos individuais de azevém perene, fato este que sugere que perfilhos de Cynodon "funcionariam" em grupos. Segundo Chapman et al. (1992a) espécies que apresentam forte integração fisiológica poderiam ter certa vantagem competitiva no sentido de que, variações de ambiente localizadas (e.g. desfolha parcial) poderiam ser compensadas através de redistribuição de foto-assimilados advindos de outros clones que mantiveram-se intactos, de tal forma que toda a planta permaneceria em equilíbrio. As fotos 5 e 6 são bastante sugestivas quanto a essa integração clonal de perfilhos em pastos de Cynodon. Como pode ser observado, existe um padrão consistente de formação de novos perfilhos num determinado estolão ou perfilho 
caracterizado pela emissão de novos pontos de crescimento (segmentos A, B, C e D na Foto 5) a intervalos sucessivos de três fitômeros. Assim, a cada dois fitômeros (setas vermelhas nas Fotos 5 e 6) um novo perfilho é emitido e raízes formadas no $3^{\circ}$ fitômero, sequência essa que se repete de forma consistente tanto em plantas em crescimento livre ou restrito de Tifton-85, Florakirk e Coastcross. Descrição de tal padrão de crescimento e desenvolvimento não foi encontrado na literatura, nem mesmo em referências pertinentes ao lançamento e descrição morfológica dos cultivares estudados (e.g. Burton, 1972; Burton et al., 1993; Mislevy et al., 1999). Este padrão de crescimento e desenvolvimento poderia estar relacionado com a agressividade e o caráter colonizador dessas plantas, uma vez que as duas folhas cujas gemas axilares não resultaram na formação de perfilhos poderiam estar sendo usadas para gerar reservas orgânicas para nutrir o perfilho e as raízes formadas num novo ponto de estabelecimento da planta, de forma a assegurar sua viabilidade e sobrevivência, já que segundo Chapman et al. (1992b) existe um custo energético para a formação e manutenção de estruturas de ligação entre perfilhos (estolão, rizoma e haste) que poderia ser usado para outro fim como, por exemplo, um maior crescimento de folhas. Apesar disso, Chapman \& Lemaire (1993) argumentaram que a integração clonal seria uma estratégia viável para plantas sob desfolha intensa, tendo em vista que o investimento de recursos em crescimento não poderia ser completamente recuperado, já que as folhas seriam, normalmente, removidas muito antes de morrerem naturalmente. 
Tabela 20. Razão área foliar:volume por perfilho (R) assumindo-se uma integração clonal entre 4 perfilhos em pastos de Cynodon spp.

\begin{tabular}{cccccc}
\hline & \multicolumn{4}{c}{ Cultivares } & \\
\cline { 2 - 4 } $\begin{array}{c}\text { Datas de } \\
\text { avaliação }\end{array}$ & Tifton 85 & Florakirk & Coastcross & Média & EPM \\
\hline 1 & $28,6^{\mathrm{a}}$ & $24,8^{\mathrm{a}}$ & $28,8^{\mathrm{a}}$ & 27,4 & 3,30 \\
2 & $34,8^{\mathrm{a}}$ & $38,2^{\mathrm{a}}$ & $32,8^{\mathrm{a}}$ & 35,2 & 3,36 \\
3 & $26,2^{\mathrm{b}}$ & $32,2^{\mathrm{a}}$ & $24,2^{\mathrm{b}}$ & 27,6 & 2,04 \\
4 & $34,2^{\text {ab }}$ & $39,8^{\mathrm{a}}$ & $29,8^{\mathrm{b}}$ & 34,6 & 3,04 \\
\hline
\end{tabular}

Médias na mesma linha seguidas de letras semelhantes não diferem entre si $(\mathrm{P}>0,10)$

EPM - Erro padrão da média. Data 1=15/12/98; Data 2=25/01/99; Data 3=07/04/99 e Data 4=04/07/99.

Tabela 21. Razão área foliar:volume por perfilho (R) assumindo-se uma integração clonal entre 4 perfilhos para as alturas de pasto estudadas.

\begin{tabular}{ccccccc}
\hline & \multicolumn{5}{c}{ Altura de pasto (cm) } \\
\cline { 2 - 5 } $\begin{array}{c}\text { Datas de } \\
\text { avaliação }\end{array}$ & 5 & 10 & 15 & 20 & Média & EPM \\
\hline 1 & $20,2^{\mathrm{a}}$ & $30,8^{\mathrm{a}}$ & $29,0^{\mathrm{a}}$ & $29,6^{\mathrm{a}}$ & 27,4 & 3,82 \\
2 & $33,0^{\mathrm{a}}$ & $36,6^{\mathrm{a}}$ & $33,6^{\mathrm{a}}$ & $37,8^{\mathrm{a}}$ & 35,2 & 3,90 \\
3 & $27,4^{\mathrm{a}}$ & $28,8^{\mathrm{a}}$ & $29,0^{\mathrm{a}}$ & $25,2^{\mathrm{a}}$ & 27,6 & 2,36 \\
4 & $32,6^{\mathrm{a}}$ & $31,8^{\mathrm{a}}$ & $37,8^{\mathrm{a}}$ & $36,2^{\mathrm{a}}$ & 34,6 & 3,50
\end{tabular}

Médias na mesma linha seguidas de letras semelhantes não diferem entre si $(\mathrm{P}>0,10)$

EPM - Erro padrão da média. Data 1=15/12/98; Data 2=25/01/99; Data 3=07/04/99 e Data 4=04/07/99. 


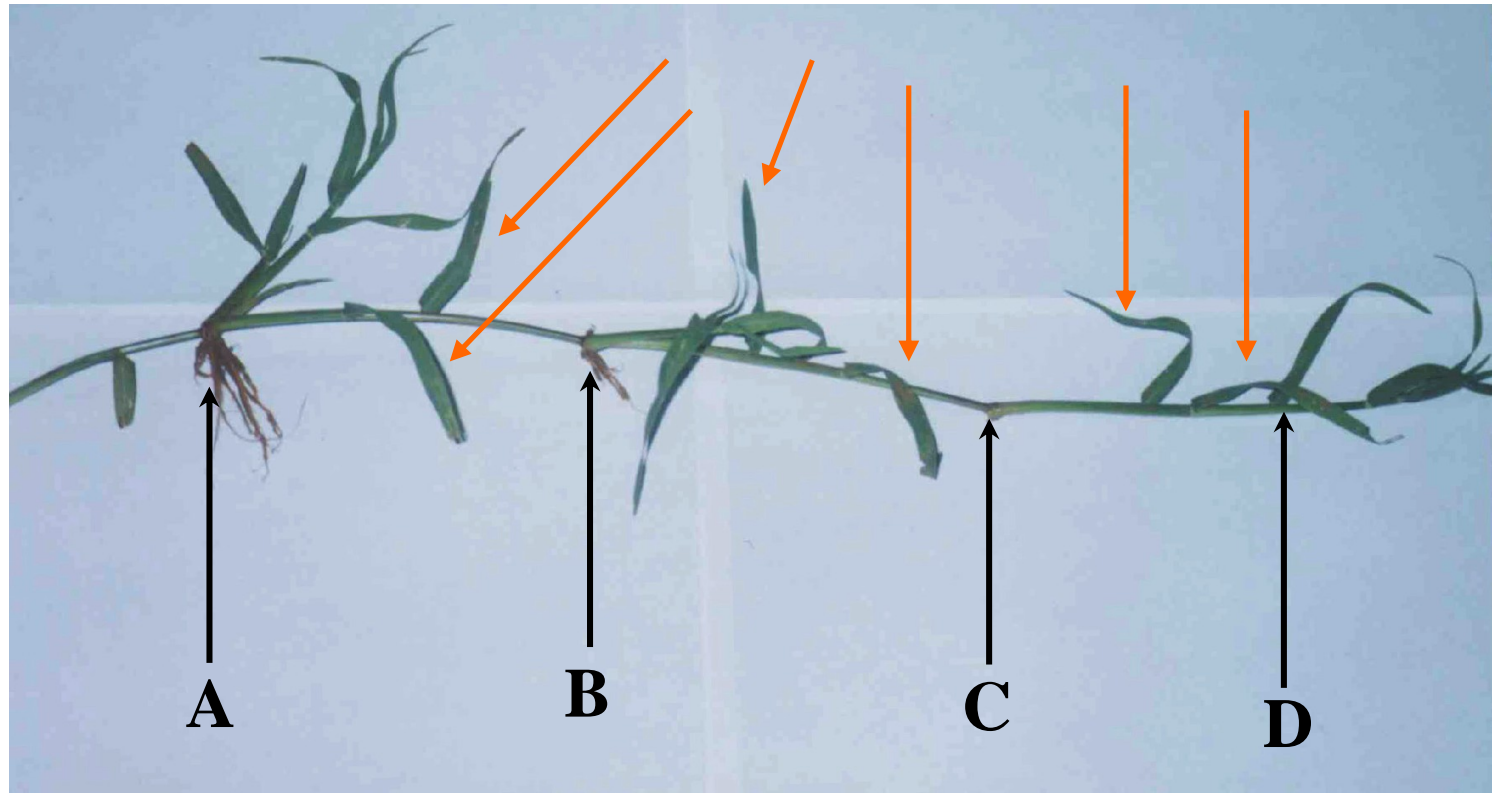

Foto 5 - Estolão de Cynodon (cultivar Tifton-85) mostrando o surgimento de novos perfilhos a partir de gemas axilares a intervalos regulares de três folhas (setas laranja) (1 perfilho a cada três folhas).

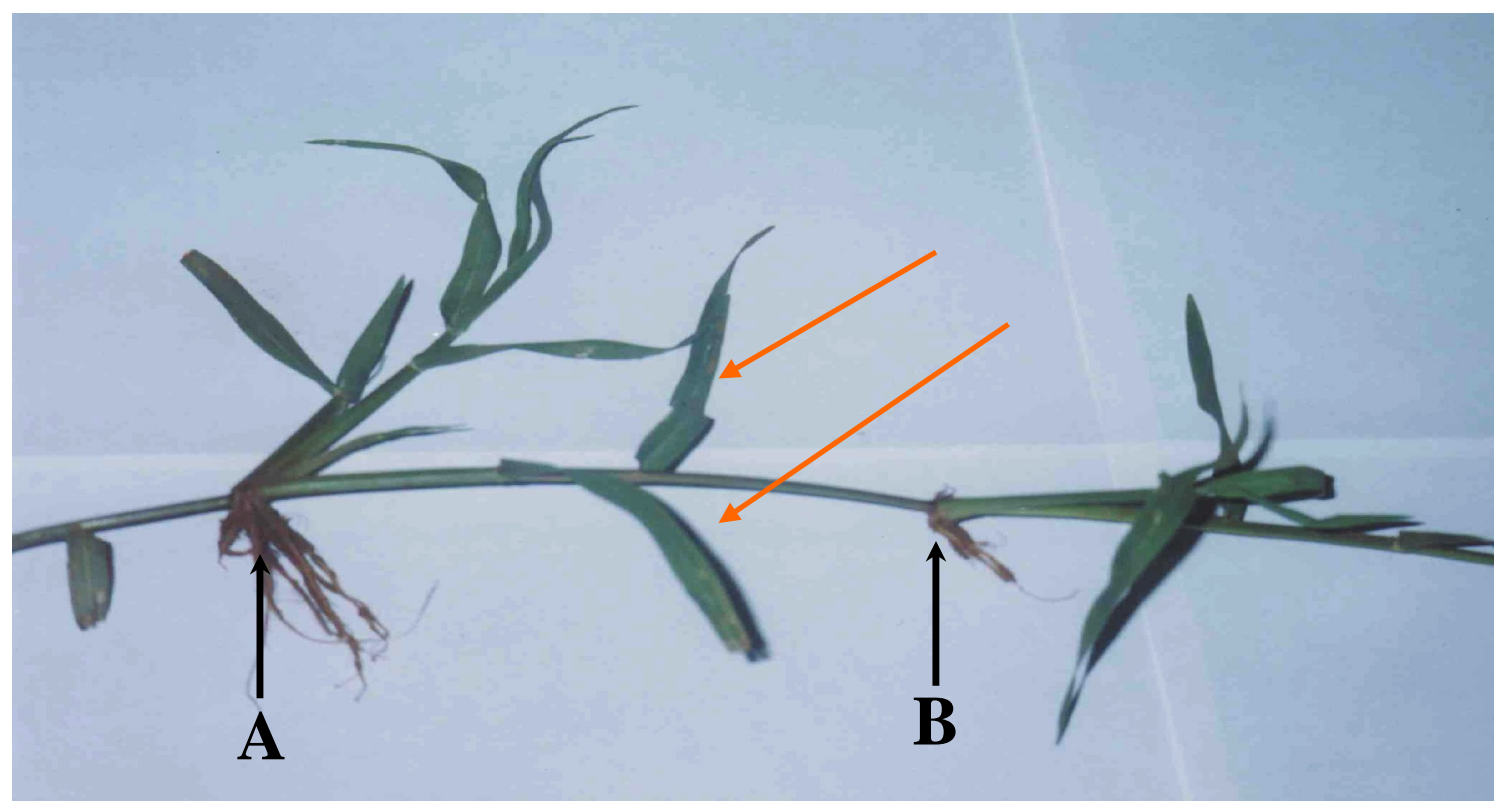

Foto 6 - Aproximação do mesmo estolão da foto acima, mostrando em detalhe os pontos de aparecimento de novos perfilhos intercalados por duas folhas. 
O fato do valor de $\mathrm{R}$ dobrar quando o cálculo é baseado na associação de quatro perfilhos, não é exclusividade de pastos de Cynodon, já que essa seria uma exigência matemática da forma como o seu cálculo é feito. Conforme mostrado por Matthew et al. (1995), o valor de $\mathrm{R}$ aumenta segundo uma razão de $\mathrm{n}^{1 / 2}$, onde $\mathrm{n}$, no caso de gramíneas, seria o número de perfilhos que estivessem agrupados clonalmente. Assim, Matthew et al. (1999), fazendo uma simulação para azevém perene, observaram que o valor de R aumentou de 50 para 86,7 quando o cálculo foi baseado na associação de três perfilhos. No entanto, o grau de integração clonal entre perfilhos de azevém perene é muito diferente do observado para Cynodon. Esse último é capaz de desenvolver estolões com mais de $2 \mathrm{~m}$ de comprimento quando em crescimento livre (ou em processo de colonização) (Foto 5) sendo também observados em menor tamanho em relvados "fechados" sob pastejo. Ainda que em pastos de azevém perene ocorra a formação de estolões (Korte \& Harris, 1987; Matthew, 1988, Da Silva, 1994), esses podem ser considerados incipientes quando comparados àqueles verificados para Cynodon.

Assim, um maior valor de $\mathrm{R}$ verificado para azevém perene, quando comparado com Cynodon, estaria relacionado com maior elongação de folhas por unidade de volume, indicando que esses não necessitariam agrupar-se em clones, pois adquirem competitividade de maneira individual, dividindo uma pequena fração de foto-assimilados com outros perfilhos. Já perfilhos de Cynodon, por apresentarem um baixo valor de R, otimizariam o IAF do pasto agrupando-se em clones, a fim de garantir persistência e competitividade. Além disso, a grandeza do valor de $\mathrm{R}$ poderia ser bastante sugestiva quanto ao padrão de integração clonal entre espécies, ou seja, quanto maior o valor de $\mathrm{R}$ menor seria a inter-dependência entre perfilhos e maior a sua capacidade de desenvolver-se de maneira individual. No entanto, convém comentar, que essa suposição tem caráter essencialmente especulativo, uma vez que dados de campo são praticamente inexistentes. Apesar dos fortes indícios de integração clonal entre perfilhos em pastagens de Cynodon, são necessários estudos adicionais sob condições controladas com a finalidade de elucidar o grau e a natureza dessa integração, de forma que uma melhor compreensão possa ser atingida sobre a persistência, competitividade e 
produtividade dessas plantas e a informação utilizada para direcionar e balizar decisões de manejo da pastagem.

\subsection{Relação funcional entre massa e densidade populacional de perfilhos}

A relação funcional (em escala logarítmica) obtida entre massa e densidade populacional de perfilhos é mostrada na Tabela 22. As regressões são do tipo $y=\beta_{0}+\beta_{1} x$, uma vez que a relação $\log$ (densidade) x log (massa por perfilho) é assumida ser linear. Quatro pares de dados foram utilizados para estabelecer a relação funcional, os quais correspondem às quatro alturas de pasto. No entanto, nas situações onde o pasto de 10 $\mathrm{cm}$ possuía maior densidade populacional de perfilhos que pastos de $5 \mathrm{~cm}$, as regressões foram traçadas com 3 pares de dados apenas, ou seja, 10, 15 e $20 \mathrm{~cm}$. Como pode ser observado, nove das doze regressões obtidas apresentaram altos coeficientes de determinação $\left(\mathrm{R}^{2}\right)$. As inclinações $\left(\beta_{1}\right)$ das retas obtidas foram maiores que a proposição teórica de -3/2 (-1,5), exceção feita ao cultivar Florakirk, nas avaliações 3 e 4, que apresentou valores próximos de $-1,7$ e $-1,15$, respectivamente (Tabela 22). Segundo Sackville Hamilton et al. (1995), uma reta de inclinação $-3 / 2$ seria uma expectativa teórica quando o IAF e a razão área foliar:volume por perfilho (R) permanecessem constantes. Como a área foliar do pasto variou com o aumento em altura do relvado (Tabela 15), seria esperado que as inclinações fossem realmente diferentes de $-3 / 2$. Hernández Garay et al. (1999) também observaram inclinações maiores que $-3 / 2$ (próximas de -5/2) para azevém perene. A inclinação da reta é determinada por duas variáveis distintas: massa e densidade populacional de perfilhos. Assim, uma inclinação de $-5,29$ (observada na $2^{\text {a }}$ avaliação para Tifton-85) seria um indicativo de uma situação onde um aumento em massa por perfilho seria seguido por uma pequena redução na DPP, sugerindo que para a amplitude de alturas de pasto estudadas provavelmente Tifton-85 não tenha sua perenidade comprometida. 
Tabela 22. Coeficientes angulares, interceptos, coeficientes de determinação e níveis de significância para as regressão $\log _{10} \mathrm{x} \log _{10}$ entre densidade populacional e massa por perfilho e valores de $\mathrm{C}_{\mathrm{a}}$ e $\mathrm{C}_{\mathrm{r}}$ em pastos de Cynodon spp.

\begin{tabular}{|c|c|c|c|c|c|c|c|c|}
\hline \multirow[b]{2}{*}{ Cultivares } & \multicolumn{7}{|c|}{ Parâmetros } & \multirow[b]{2}{*}{$\begin{array}{l}\text { Inclinação } \\
\text { predita }(\beta)^{*}\end{array}$} \\
\hline & $\beta_{0}$ & $\beta_{1}$ & Modelo & $\mathrm{R}^{2}$ & $\mathrm{p}_{\text {modelo }}$ & $\mathrm{C}_{\mathrm{a}}$ & $\mathrm{C}_{\mathrm{r}}$ & \\
\hline \multicolumn{9}{|c|}{ Avaliação 1 (15/12/98): } \\
\hline Tifton 85 & 3,85 & $-2,0072$ & $Y=3,85-2,01 x$ & 0,989 & 0,0054 & 1,14 & $-0,73$ & $-1,91$ \\
\hline Florakirk & 5,05 & $-2,3284$ & $Y=5,05-2,33 x$ & 0,912 & 0,0452 & 1,85 & $-0,65$ & $-2,70$ \\
\hline Coastcross & 3,86 & $-2,0538$ & $Y=3,86-2,05 x$ & 0,962 & 0,0192 & 0,82 & $-0,28$ & $-2,04$ \\
\hline \multicolumn{9}{|c|}{ Avaliação 2 (25/01/99): } \\
\hline Tifton 85 & 17,6 & $-5,2962$ & $Y=17,6-5,30 x$ & 0,973 & 0,0138 & 4,36 & $-0,18$ & $-5,68$ \\
\hline Florakirk & $-5,3$ & 0,2112 & $Y=-5,3+0,21 x$ & 0,011 & 0,8974 & $\mathrm{NC}$ & $\mathrm{NC}$ & $\mathrm{NC}$ \\
\hline Coastcross & 7,35 & $-2,9267$ & $Y=7,35-2,93 x$ & 0,727 & 0,1472 & 4,61 & $-0,70$ & $-5,41$ \\
\hline \multicolumn{9}{|c|}{ Avaliação 3 (07/04/99): } \\
\hline Tifton 85 & 10,0 & $-3,4410$ & $Y=10,0-3,44 x$ & 0,996 & 0,0382 & 3,47 & $-1,65$ & $-3,32$ \\
\hline Florakirk & 2,57 & $-1,6863$ & $Y=2,57-1,69 x$ & 0,981 & 0,0883 & 0,59 & $-0,80$ & $-1,29$ \\
\hline Coastcross & 11,4 & $-3,8341$ & $Y=11,4-3,83 x$ & 0,998 & 0,0262 & 1,45 & $-0,59$ & $-2,36$ \\
\hline \multicolumn{9}{|c|}{ Avaliação 4 (04/07/99): } \\
\hline Tifton 85 & $-3,21$ & $-0,2754$ & $Y=-3,21-0,28 x$ & 0,039 & 0,8018 & $\mathrm{NC}$ & $\mathrm{NC}$ & $\mathrm{NC}$ \\
\hline Florakirk & 0,40 & $-1,1464$ & $Y=0,40-1,15 x$ & 0,977 & 0,0960 & 0,59 & -061 & $-1,48$ \\
\hline Coastcross & $-5,7$ & 0,3072 & $Y=-5,7+0,31 x$ & 0,022 & 0,8524 & $\mathrm{NC}$ & $\mathrm{NC}$ & $\mathrm{NC}$ \\
\hline
\end{tabular}


No outro extremo, o cultivar Florakirk apresentou inclinação de reta de $-1,15$ na $4^{\mathrm{a}}$ avaliação. Essa situação indica que um aumento em massa por perfilho seria conseguido às custas de uma grande redução em densidade populacional, sugerindo, provavelmente, que se a altura de pasto aumentar muito a redução em DPP poderia comprometer a persistência do estande. Segundo Matthew et al. (1995), uma inclinação próxima de -1 significa que o estande não aumenta em biomassa aérea total, no entanto a redução em número de perfilhos continuaria ocorrendo. Como pode ser observado na Tabela 11 o aumento em biomassa no cultivar Florakirk, entre as alturas de 10 e $20 \mathrm{~cm}$ (alturas utilizadas para verificação da inclinação) na $4^{a}$ avaliação, foi de $31 \%$, enquanto que nas outras avaliações, em todos os cultivares, o aumento em biomassa (considerando os dois extremos de altura do pasto utilizadas na verificação da inclinação) foi sempre superior a 67\%, chegando, em várias situações, a mais de 300\%. Além disso, esses dados indicariam, provavelmente, que os cultivares Tifton-85 e Coastcross possuem potencial de acúmulo de biomassa aérea superior ao limite de $20 \mathrm{~cm}$ de altura imposto neste estudo, enquanto que para o cultivar Florakirk, provavelmente, esse limite estaria, para a $3^{\underline{a}}$ e $4^{\underline{a}}$ avaliações, ao redor de $20 \mathrm{~cm}$. No entanto, tais suposições só poderiam ser confirmadas em experimentos onde o limite máximo de altura imposto ultrapassasse a de $20 \mathrm{~cm}$.

As correções $\mathrm{C}_{\mathrm{a}}$ e $\mathrm{C}_{\mathrm{r}}$ foram eficazes em explicar os desvios das retas geradas em relação à expectativa teórica de $-3 / 2$ para Tifton- 85 em todas as avaliações. Para Coastcross isso ocorreu apenas na $1^{\underline{a}}$ avaliação e para Florakirk os desvios foram explicados apenas parcialmente (Tabela 22). Um dos principais fatores que poderia ter influenciado a discrepância entre a inclinação observada e a inclinação predita por $\mathrm{C}_{\mathrm{a}} \mathrm{e}$ $\mathrm{C}_{\mathrm{r}}$ para o cultivar Coastcross nas avaliações 2 e 3 , seria o florescimento heterogêneo verificado nesse cultivar, ou seja, alturas diferentes florescendo em épocas diferentes modificariam a estrutura do pasto, o que interferiria sobre as variáveis fundamentais para a predição da inclinação, quais sejam, densidade populacional, área foliar e volume por perfilho. Já o cultivar Florakirk apresentou um florescimento menos intenso que Coastcross, fato que pode justificar a menor discrepância entre o valores observados e aqueles preditos por $\mathrm{C}_{\mathrm{a}}$ e $\mathrm{C}_{\mathrm{r}}$. 
Apesar dessas limitações, observa-se que os valores de $C_{a}$ são maiores que aqueles de $\mathrm{C}_{\mathrm{r}}$ em praticamente todas as avaliações, indicando que em pastagens de Cynodon a variação em IAF é o principal fator determinante do mecanismo de compensação, de maneira semelhante ao que ocorre para azevém perene (Matthew et al., 1999; Hernández Garay et al., 1999). Adicionalmente, os valores de $C_{a}$ seriam mais determinantes das inclinações das retas que $\mathrm{C}_{\mathrm{r}}$, ou seja, as variações na forma do perfilho (variação em R - ocupação espacial) tomariam uma maior importância apenas quando os perfilhos entrassem em processo reprodutivo. Isso é particularmente verificado para o cultivar Florakirk na $3^{\underline{a}}$ e $4^{\underline{a}}$ avaliações onde ocorreu florescimento e foram verificados valores de $C_{r}$ maiores que $C_{a}$ (Tabela 22).

Segundo Niklas (1994), a inclinação da reta estaria diretamente relacionada com a habilidade de diferentes espécies em tolerar sombreamento, déficit hídrico e outros fatores de estresse e, segundo esse mesmo autor, cerca de $50 \%$ da variação no valor absoluto da inclinação poderiam ser atribuídos à variação na forma e no padrão de alocação de biomassa paras as diferentes partes da planta. Assim, Fagundes (1999), em trabalho concomitante, observou diferenças morfofisiológicas entre os cultivares estudados, caracterizadas principalmente por variações no coeficiente de extinção luminosa $(\mathrm{k})$, fato esse que sugere que os mesmos possuem diferenças quanto à disposição de folhas (ângulo foliar) e padrões de interceptação luminosa para um mesmo IAF. Além disso, os diferentes padrões de florescimento entre cultivares sugerem que existem variações sazonais nos processos de alocação de fotoassimilados para as diversas partes das plantas. Esses fatores poderiam explicar as diferenças observadas entre cultivares na inclinação das retas (Tabela 22).

\subsection{Implicações agronômicas}

Matthew et al. (1995) sugeriram que a distância de qualquer ponto, relacionando massa e densidade populacional de perfilhos, para a linha teórica de inclinação $-3 / 2$ poderia ter valor como um índice de produtividade do pasto. Como 
mostrado por Sackville Hamilton et al. (1995), a reta $-3 / 2$ define uma situação onde o IAF passa a ser constante. Dessa maneira, quanto maior a distância entre os pontos observados e reta $-3 / 2$, maior o IAF e, consequentemente, maior sua capacidade de acúmulo de matéria seca. Essa hipótese foi confirmada para plantas de clima temperado através de experimentos em micro-relvados (Hernández Garay et al., 1999) e em situações de campo (Hernández Garay et al., 1996; Bahmani et al., 1998). As correlações entre a distância dos pontos observados e seus correspondentes na reta $-3 / 2$ e o IAF atual do pasto são mostradas nas Tabelas 23, 24 e 25. Como pode ser observado as correlações foram significativas (a única exceção foi o cultivar Florakirk na $4^{\text {a }}$ avaliação), indicando que a distância entre os pontos obtidos (resultado da combinação de massa e densidade populacional de perfilhos) e a reta $-3 / 2$ poderia ter valor para predizer, em espécies do gênero Cynodon, o IAF do pasto, variável essa considerada fundamental na compreensão dos processos de acúmulo de matéria seca (Lemaire \& Agnusdei, 1999) e manejo da desfolha (Lemaire \& Chapman, 1996).

É inegável que massa por perfilho e densidade populacional de perfilhos são variáveis mais fáceis de serem medidas que o IAF do pasto. Dessa forma, uma compreensão mais apurada dos mecanismos de compensação ao longo do ano, e em diversas situações poderia, no futuro, fornecer condições para que amostragens de massa de perfilho e DPP fornecessem, com alto grau de confiabilidade, o IAF do pasto e, da mesma maneira, uma predição da capacidade de acúmulo de matéria seca da pastagem. 
Tabela 23. Correlação (R) entre a distância de pontos de coordenadas x/y (em unidades logarítmicas) à reta de inclinação teórica $-3 / 2$ e o IAF atual do pasto (cultivar Coastcross).

\begin{tabular}{ccccccc}
\hline \multirow{2}{*}{$\begin{array}{c}\text { Altura de } \\
\text { pasto }(\mathrm{cm})\end{array}$} & \multicolumn{2}{c}{ Avaliação 1 } & \multicolumn{2}{c}{ Avaliação 2 } & \multicolumn{2}{c}{ Avaliação 3 } \\
\cline { 2 - 7 } & Distância & IAF & Distância & IAF & Distância & IAF \\
\hline 5 & 0,084 & 1,75 & 0,042 & 1,39 & 0,056 & 1,25 \\
10 & 0,126 & 2,43 & 0,194 & 2,16 & 0,236 & 2,24 \\
15 & 0,192 & 2,63 & 0,163 & 2,32 & 0,269 & 1,99 \\
20 & 0,190 & 2,55 & 0,302 & 3,16 & 0,380 & 2,81 \\
\hline $\mathrm{R}$ & \multicolumn{2}{c}{0,906} & 0,976 & 0,964 & \\
$\mathrm{P}$ & 0,0943 & 0,0237 & 0,0359 & \\
\hline
\end{tabular}

Avaliação 1 = 15/12/98, Avaliação 2 = 25/01/99 e Avaliação 3 = 07/04/1999. 
Tabela 24. Correlação (R) entre a distância de pontos de coordenadas x/y (em unidades logarítmicas) à reta de inclinação teórica $-3 / 2$ e o IAF atual do pasto (cultivar Florakirk).

\begin{tabular}{ccccccc} 
Altura de & \multicolumn{2}{c}{ Avaliação 1 } & \multicolumn{2}{c}{ Avaliação 3 } & \multicolumn{2}{c}{ Avaliação 4 } \\
\cline { 2 - 7 } pasto (cm) & Distância & IAF & Distância & IAF & Distância & IAF \\
\hline 5 & 0,211 & 1,42 & 0,042 & 1,61 & 0,068 & 2,50 \\
10 & 0,307 & 2,86 & 0,275 & 3,27 & 0,248 & 2,90 \\
15 & 0,317 & 2,42 & 0,326 & 3,47 & 0,224 & 4,48 \\
20 & 0,335 & 2,56 & 0,319 & 2,45 & 0,234 & 3,84 \\
\hline R & 0,9018 & 0,824 & & 0,466 & \\
P & 0,0982 & 0,1645 & 0,5334 & \\
\hline
\end{tabular}

Avaliação 1 = 15/12/98, Avaliação 3 = 07/04/99 e Avaliação 4 = 04/07/99. 
Tabela 25. Correlação (R) entre a distância de pontos de coordenadas x/y (em unidades logarítmicas) à reta de inclinação teórica $-3 / 2$ e o IAF atual do pasto (cultivar Tifton-85).

\begin{tabular}{ccccccc}
\hline \multirow{2}{*}{$\begin{array}{c}\text { Altura de } \\
\text { pasto }(\mathrm{cm})\end{array}$} & \multicolumn{2}{c}{ Avaliação 1 } & \multicolumn{2}{c}{ Avaliação 2 } & \multicolumn{2}{c}{ Avaliação 3 } \\
\cline { 2 - 7 } & Distância & IAF & Distância & IAF & Distância & IAF \\
\hline 5 & 0,207 & 1,94 & 0,146 & 1,90 & 0,145 & 1,46 \\
10 & 0,276 & 2,54 & 0,276 & 2,48 & 0,376 & 2,47 \\
15 & 0,307 & 3,52 & 0,326 & 2,75 & 0,420 & 3,47 \\
20 & 0,319 & 3,64 & 0,409 & 4,16 & 0,489 & 4,25 \\
\hline R & \multicolumn{2}{c}{0,957} & 0,933 & & 0,943 & \\
P & \multicolumn{2}{c}{0,0428} & 0,0662 & 0,0569 & \\
\hline
\end{tabular}

Avaliação $1=15 / 12 / 98$, Avaliação $2=25 / 01 / 99$ e Avaliação 3 = 07/04/1999. 


\section{CONCLUSÕES}

A partir dos resultados obtidos, as seguintes conclusões puderam ser elaboradas:

O mecanismo de compensação tamanho/densidade populacional de perfilhos, originalmente descrito e elaborado para plantas forrageiras de clima temperado, opera em pastagens de Cynodon. No entanto, as inclinações das retas foram consistentemente maiores que a proposição teórica de $-3 / 2$.

Perfilhos individuais de Cynodon apresentaram um padrão de crescimento isométrico e parecem agrupar-se em clones para assegurar estratégia competitiva e otimização de IAF.

Os resultados sugerem ainda que pastagens de Cynodon não tolerem pastejos intensos $(5 \mathrm{~cm})$ no período de outono por não conseguirem compensar a reduzida altura de desfolha com aumentos em densidade populacional de perfilhos.

O estádio reprodutivo das plantas interferiu de forma significativa nos processos de competição intra-específica e dinâmica populacional de perfilhos nos três cultivares de Cynodon estudados, sendo este efeito altamente dependente de cultivar e época do ano. 


\section{REFERÊNCIAS BIBLIOGRÁFICAS}

BAHMANI, I.; THOM, E.R.; MATTHEW, C. Effects of nitrogen and irrigation on productivity of different ryegrass ecotypes when grazed by dairy cows. In: ANNUAL MEETING OF THE NEW ZEALAND GRASSLAND ASSOCIATION, 59, 1998. Proceedings. p. 117-123.

BINNIE, R.C.; CHESTNUTT, D.M.B. Effect of regrowth interval on productivity of swards defoliated by cutting and grazing. Grass and Forage Science, v.46, p.343350, 1991.

BIRCHAM, J.S.; HODGSON, J. The influence of sward conditions on rates of herbage growth and senescence in mixed swards under continuous grazing management. Grass and Forage Science, v.38, p.323-331, 1983.

BRASIL. Ministério da Agricultura. Serviço Nacional de Pesquisa Agronômica. Comissão de Solos. Levantamento de reconhecimento dos solos do estado de São Paulo. Rio de Janeiro, 1960. 634p. (Boletim, 12).

BRISKE, D.D. Strategies of Plant Survival in Grazed Systems: A Functional Interpretation. In: HODGSON, J.; ILLIUS, A.W. (Ed.) The ecology and management of grazing systems. Guildford: CAB International, 1996. cap.2, p.3667.

BROUGHAM, R.M. Interception of light by the foliage of pure and mixed stands of pasture plants. Australian Journal of Agricultural Research, v.9, p.39-52, 1957. 
BURTON, G.W. Registration of 'Coastcross-1' bermudagrass. Crop Science. v.12, p.125, 1972.

BURTON, G.W.; GATES, R.N.; HILL, G.M. Registration of 'Tifton-85' bermudagrass. Crop Science, v.33, p.644-645, 1993.

CAMPBELL, G.S. An introduction to Environmental Biophysics. Springer-Verlug, 1977.

CARNEVALLI, R.A.; Da SILVA, S.C. Avaliação de algumas características agronômicas e ecológicas de plantas da espécie Cynodon dactylon cv. Coastcross para fins de validação de técnicas para ensaios de pastejo com plantas forrageiras. Scientia Agricola, v.56, p.489-499, 1999.

CARVALHO, C.A.B. Padrões demográficos de perfilhamento e acúmulo de forragem em pastagens de Cynodon spp. manejadas em quatro intensidades de pastejo. Piracicaba, 2000. 96p. Dissertação (M.S.) - Escola Superior de Agricultura "Luiz de Queiroz", Universidade de São Paulo.

CHAPMAN, D.F.; ROBSON, M.J.; SNAYDON, R.W. Physiological integration in the clonal perennial herb (Trifolium repens L.). Oecologia, v.89, p.338-347, 1992a.

CHAPMAN, D.F.; ROBSON, M.J.; SNAYDON, R.W. The growh and carbon allocation patterns of white clover (Trifolium repens L.) plants of contrastings branching structure. Journal of Experimental Botany, v.69, p.523-531, 1992 b.

CHAPMAN, D.F.; LEMAIRE, G. Morphogenetic and strutural deterninants of plant regrowth after defoliation. In: BACKER M. J. (Ed). Grassland of our world. Wellington: SIR Publishing, 1993. cap.3, p.55-64.

COLVILL, K.E.; MARSHALL, C. Tiiller dynamics and asimilate partitioning in Lolium perene with particular reference to flowering. Annals of Applied Biology, v.104, p.543-557, 1984. 
COOPER, J.P. Physiological and morphological advances for forage improvement. In:

INTERNATIONAL GRASSLAND CONGRESS, 14, Lexington, 1981. Proceedings. Boulder, CO.: Westview Press, 1983.

CURLL, M.L.; WILKINS, R.J.; SNAYDON, R.W; SHANMUGALINGAM, V.S. The effects of stocking rate and nitrogen fertiliser on a perennial ryegrass-white clover sward, 1 - Sward and sheep performance. Grass and Forage Science, v.40, p.129$140,1985$.

Da SILVA. A study of spring grazing management effect on summer-autumn pasture and milk production of perennial ryegrass $\mathrm{x}$ white clover dairy swards. Palmerston North, 1994. 217p. Thesis (Ph.D.) - Massey University.

Da SILVA, S.C.; PEDREIRA, C.G.S. Princípios de ecologia aplicados ao manejo da pastagem. In: SIMPÓSIO SOBRE ECOSSISTEMA DE PASTAGENS, 3, Jaboticabal, 1997. Anais. Jaboticabal: FUNEP, 1997. p.1-62.

DAVIES, A. Structure of the grass swards. INTERNATIONAL MEETING ON ANIMAL PRODUCTION FROM TEMPERATE GRASSLAND. Dublin, 1977. Proceedings, 1977. p.36-44.

DAVIES, A. Tissue turnover in the sward. In: HODGSON, J.; BAKER, A.; DAVIES, A.S.L.; LEAVER, J.D. (Eds.). Sward measurement handbook. Hurley: British Grassland Society, 1981. Cap.9, p.179-208.

DAVIES, A. The regrowth of grass swards. In: JONES, M.B.; LAZENBY, A. (Eds.) The grass crop. London: Chapman and Hall, 1988, p.85-127.

ESALQ. Departamento de Ciências Exatas endabreu/MEDIAS.TXT (20 set. 1999).

FAGUNDES, J.L. Efeito de intensidades de pastejo sobre o índice de área foliar, interceptação luminosa e acúmulo de forragem em pastagens de Cynodon spp. 
Piracicaba, 1999. 69p. Dissertação (M.S.) - Escola Superior de Agricultura "Luiz de Queiroz”, Universidade de São Paulo.

GOMIDE, C.C.C. Algumas características fisiológicas e químicas de cinco cultivares de Cynodon. Jaboticabal, 1996. 100p. Dissertação (mestrado) - Faculdade de Ciências Agrárias e Veterinárias, Universidade Estadual Paulista “Júlio de Mesquita Filho".

GOMIDE, C.A.M.; GOMIDE, J.A. Morfogênese e análise de crescimento de cultivares de $P$. maximum. In: REUNIÃO ANUAL DA SOCIEDADE BRASILEIRA DE ZOOTECNIA, 33., Fortaleza, 1996. Anais. Fortaleza: SBZ, 1996, p.403-406.

GRANT, S. A.; KING, J. Grazing management and pasture production: the importance of sward morphological adaptations and canopy photosyntesis. The Hill Farming Research Organization, v.83, p.119-129, 1982.

GRANT, S.A.; BARTHRAM, G.T.; TORVELL, L.; KING, J.; SMITH, H.K. Sward management lamina turnover and tiller population density in continuously stocked Lolium perenne - dominated swards. Grass and Forage Science, v.38, p.333-344, 1983.

HARPER, J.L. Population biology of plants. London: Academic Press, 1977.

HERNÁNDEZ GARAY, A.; MATTHEW, C.; HODGSON, J. Effect of spring management on perenial ryegrass and ryegrass-white clover pastures. 2 - tiller and growing point densities and population dynamics. New Zeland Journal of Agricultural Research, v.40, p.37-50, 1997.

HERNÁNDEZ GARAY, A.; MATTHEW, C.; HODGSON, J. Tiller size-density compensation in ryegrass miniature swards subject to differing defoliation heights and a proposed productivity index. Grass and Forage Science, v.54, n.4, p.347$356,1999$. 
HODGSON, J. Grazing management - science into practice. Essex: Longman Scientific \& Technical, 1990.

HUMPHREYS, L.R. Subtropical grass growth: II Effects on variation in leaf area index in the field. Queenland Journal of Agricultural and Animal Science, v.23, p.388-358, 1966.

HUTCHINGS, M.J.; BUDD, C.S. Plant competition and its course through time. Bioscience, v.31, p.640-645, 1981a.

HUTCHINGS, M.J.; BUDD, C.S. Plant self-thinning and leaf area dynamics in experimental and natural monocultures. Oikos, v.36, p.319-325, 1981 b.

KAYS, S.; HARPER, J.L. The regulation of plant and tiller density in a grass sward. Journal of Ecology, v.62, p.97-105, 1974.

KORTE, C.J.; WATKIN, B.R.; HARRIS, W. Effects of the timing and intensity of spring grazings on reproductive developtment, tillering, and herbage production of perenial ryegrass ominant pasture. New Zeland Journal of Agricutural Research, v.27, p.135-149, 1984.

KORTE, C.J. Tillering in "Grasslands Nui" perennial ryegrass swards. 2. - Seasonal pattern of tillering and age of flowering tillers with two mowng frequencies. New Zeland Journal of Agricutural Research, v.29, p.629-638, 1986.

KORTE, C.J.; HARRIS, W. Stolon development in grazed 'Grassland Nui' perennial ryegrass. New Zealand Journal of Agricultural Research, v.30, p.139-148, 1987.

LAMBERT, M.G.; CLARK, D.A.; GRANT, D.A.; COSTALL, D.A.; GRAY, Y.S. Influence of fertiliser and grazing management on North Island moist hill country 4. Pastures species abundance. New Zealand Journal of Agricultural Research, v.29, p.23-31, 1986. 
LANGER R.H.M. Tillering in herbage grass. A review. Herbage Abstracts, v.33, p.141-148, 1963.

LANGER, R.H.M. Tillering. In: LANGER, R.H.M (Ed). How grasses grow. London: Edward Arnold, 1979. cap.5, p.19-25.

LEMAIRE, G.; CHAPMAN, D. Tissue flows in grazed plant communities. In: HODGSON, J.; ILLIUS, A.W. (Ed.) The ecology and management of grazing systems. Guildford: CAB International, 1996. cap.1, p.3-36.

LEMAIRE, G.; AGNUSDEI, M. Leaf tissue turn-over and efficiency of herbage utilisation. In: SIMPÓSIO INTERNACIONAL "GRASSLAND ECOPHYSIOLOGY AND GRAZING ECOLOGY”, Curitiba, 1999. Anais. Curitiba: UFPR/UFRGS, 1999. p.165-183.

LONSDAlE, W.M.; WATKINSON, A.R. Light and self-thinning. New Phytologist, v.90, p.431-445, 1982.

LONSDALE, W.M.; WATKINSON, A.R. Plant geometry and self-thinning. Journal of Ecology, v.71, p.285-297, 1983.

LONSDALE, W.M. The selh-thinning rule: dead or alive? Ecology, v.71, p.1373-1388, 1990.

LOUIE, K.; CLARK, H.; NEWTON, P.C.D. Analysis of differential equation models in biology: a case study for clover meristem populations. New Zealand Journal of Agricultural Research, v.41, n.4, p.567-576, 1998.

MADAKADZE, I.C.; COULMAN, B.E.; PETERSON, P.; STEWART, K.A.; SAMSON, R.; SMITH, D.L. Leaf area development, light intercerption, and yield among switchgrass populations in a short-season area. Crop Science, v.38, p.827834, 1998. 
MARSHALL, C. Physiological aspects of pasture growth. In: SNAYDON, R.W. (Ed.). Managed Grasslands. Amsterdam: Elsevier, 1987. cap. 4, p.29-46.

MATTHEW, C.; QUILTER, S.J.; KORTE, C.J.; CHU, A.C.P.; MACKAY, A.D. Stolon formation and significance for sward tiller dynamics in perennial ryegrass. ANNUAL MEETING OF THE NEW ZEALAND GRASSLAND ASSOCIATION, 50, 1989. Proceedings. p.255-259.

MATTHEW, C. A study of seasonal root and tiller dynamics in swards of perennial ryegrass (Lolium perenne L.). Palmerston North, 1992. 110p. Thesis (Ph.D.) Massey University.

MATTHEW, C.; LEMAIRE, G.; SACKVILLE HAMILTON, N.R.; HERNÁNDEZ GARRAY, A. A modified self-thinning equation do describe size / density relationships for defoliated swards. Annals of Botany, v.76, p.579-587, 1995.

MATTHEW, C.; ASSUERO, S.G.; BLACK, C.K.; SACKVILLE HAMILTON. Tiller dynamics of grazed swards. In: SIMPÓSIO INTERNACIONAL "GRASSLAND ECOPHYSIOLOGY AND GRAZING ECOLOGY”, Curitiba, 1999. Anais. Curitiba: UFPR/UFRGS, 1999. p.109-133.

McMAHON, C. Size and shape in biology. Science, v.179, p.1201-1204, 1973.

McMAHON, C.; KRONAUER, R.E. Tree structures: deducing the principle of mechanical design. Journal of Theoretical Biology, v.59, p.443-466, 1976.

MITCHELL, K.J; GLENDAY, A.C. The tiller population of pastures. New Zealand Journal of Agricultural Research, v.1, p.305-318, 1958.

MITCHELL, R.B.; LOWELL, E.M.; KENETH, J.M., DAREN, D.R. Tiller demographics and area index of four perenial pasture grasses. Agronomy Journal, v.90, p.47-53, 1998. 
MISLEVY, P.; BROWN, W.F.; KALMBACHER, R.S.; DUNAVIN, L.S.; JUDD, W.S.; KUCHAREK, O.C.; RUELKE, J.W.; NOLING, R.; SONODA, M.; STANLEY JR, L. Registration of 'Florakirk' Bermudagrass. Crop Science, v.39, p.587, 1999.

MORRIS, E.C.; MYERSCOUGH, P.J. Self-thinning and competition intensity over a gradient of nutrient availability. Journal of Ecology, v.79, p.903-923, 1991.

MOTT, G.O.; POPENOE, H.L. Grasslands. In: ALVIM, P.T.; KOZLOWSKI, T.T. (Ed.) Ecophysiology of tropical crops. New York: Academic Press, 1977. P.157-186.

NABINGER, C. MEDEIROS, R.B. Produção de sementes de Panicum maximum, Jacq. In: SIMPÓSIO SOBRE MANEJO DA PASTAGEM, 12, Piracicaba, 1995. Anais. Piracicaba: FEALQ, 1995. p.59-128.

NELSON, C.J., ZARROUGH, K.M. Tiller density and tiller weigth as yiel determimination of vegetative swards. Plant physiology and Herbage Production, v.13, p.25-29, 1981. (Ocasional Symposium)

NEUTEBOOM, J.H.; LANTINGA, E.A.; SCHLEPERS, H.; t'MANNETJE, L. Sward characteristics of a diploid and tetraploid cultivar of perennial L. perenne as measured by different sampling techniques. In: INTERNATIONAL GRASSLANDS CONGRESS, New Zealand and Australia, 1993. Proceedings. p.362-363.

NIKLAS, K.J. Plant allometry: The scaling process. Chicago: University of Chicago Press, 1994.

OMETTO, J.C. Registros e estimativas dos parâmetros meteorológicos da região de Piracicaba. Piracicaba: FEALQ, 1989. 76p.

ONG, C.K.; MARSHALL, C.; SAGAR, G.R. The physiology of tiller death in grasses. 2. Causes of tiller death in grass sward. Journal of the British Grassland Society, v.17, p.205-211, 1978. 
PARSONS, A.J; LEAFE, E.L.; COLLET, B.; STILES, W. The physiology of grass production under grazing. 1. Characteristics of leaf and canopy photosynthesis of continuously grazed swards. Journal of Applied Ecology, v.20, n.1, p.117-126, 1983.

PARSONS, A.J.; JOHNSON, I.R.; HARVEY, A. Use of a model to optimize the interaction between frequency and severity of intermittent defoliation and to provide a fundamental comparison of the continuous and intermittent defoliation of grass. Grass and Forage Science, v.43, n.1, p.49-59, 1988.

PUNTIERI, J.G. The self-thinning rule: bibliography revision. Preslia, Praha, v.65, p.243-268, 1993.

SACKVILLE HAMILTON, N.R.; MATTHEW, C.; LEMAIRE, G. In defence of the $-3 / 2$ boundary rule: a re-evaluation of self thinning concepts and status. Annals of Botany, v.76, p.569-577, 1995.

SAS INSTITUTE. SAS user's guide: release. 6.03, Cary, 1998. 1028p.

THOM, E.R.; BRYANT, A.M. Effects of grazing management on grass tiller density characeristics of a ryegrass-white clover dairy pasture. In: INTERNATIONAL GRASSLAND CONGRESS, 17. New Zealand and Australia, 1993. Proceedings. p.877-899.

VOLENEC, J.J.; NELSON, C.J. Responses of tall fescue leaf meristem to $\mathrm{N}$ fertilization and harvest frequency. Crop Science, v.23, p.720-724, 1983.

WELLER, D.E. A mathematical and statistical analysis of the $-3 / 2$ power rule of selfthinning in even-aged plant populations. Knoxville, 1985. 241p. Thesis (Ph.D.) University of Tennessee.

WELLER, D.E. Self thinning exponent correlated with allometric measures of plant geometry. Ecology, v.68, p.813-821, 1987. 
WELLER, D.E. The interspecific size-density relationship among crowed plant stands and its implication for the $-3 / 2$ power rule of self-thinning. American Naturalist, v.133, p.20-41, 1989.

WELLER, D.E. Will the real self-thinning rule please stand up? - a reply to Osawa and Sugita. Ecology, v.71, p.1204-1207, 1990.

WELLER, D.E. The self-thinning rule - dead or unsupported? a reply to Lonsdale. Ecology, v.72, p.747-750, 1991

WESTOBY, M. The self-thinning rule. Advances in Ecological Research, v.14, p.41$76,1984$.

WESTOBY, M.; HOWELL, J. Self-thinning: the effect of shading on glasshouse populations of silver beet (Beta vulgaris). Journal of Ecology, v.69, p.359-365, 1981.

WESTOBY, M.; HOWELL, J. Self-thinning in Trifolium subterraneum populations transferred between full daylight and shasde. Journal of Ecology, v.70, p.615-621, 1982.

WHITE, J.; HARPER, J.L. Correlated changes in plant size and number in plant populations. Journal of Ecology, v.58, p.467-485, 1970.

WHITE, J. Demographic factors in population of plants. In: SOLBRIG, O.T. (Ed.) Demography and evolution in plant population. Berkeley, California: University of California Press, 1980, p.21-48.

WHITE, J. The allometric interpretation of the self-thinning rule. Journal of Theoretical Biology, v.89, p.475-500, 1981.

WHITE, J. The thinning rule and its application to mixtures of plant populations. In: WHITE, J. (Ed.) Studies on plant demography. London: Academic Press, 1985, p.291-309. 
WOODWARD, S.J. Quantifyling different causes of leaf and tiller death in grazed perennial ryegrass swards. New Zeland Journal of Agricultural Research, v.41, p.149-159, 1998.

XIA, J.X. The effects of defoliation on tissue turnover and pasture production in perennial ryegrass, prairie grass, and smooth bromegrass, pasture. Palmerston North, 1991. Thesis (Ph.D.) - Massey University.

YANG, J.Z.; MATTHEW, C.; ROWLAND, R.E. Tiller axis observations for perennial ryegrass (Lolium perenne L.) and tall fescue (Festuca arundinaceae Schreb.): number of active phytomers probability of tiller appearance and number of roots per phytomer for three cutting heights. New Zealand Journal of Agricultural Research, v.41, p.11-19, 1998.

YODA, K.; KIRA, T.; OGAWA, H.; HOZUMI, K. Intraspecific competition among higher plants. XI Self-thinning in overcrowded pure stands under cultivate and natural conditions. Journal of Institute of Polytechnics (Osaka City University. Series D), v.14, p.107-129, 1963.

ZARROUGH, K.M.; NELSON, C.J.; SLEPER, D.A. Interrelatonsships btweem rates of appearance and tillering in selected tall fescue populations. Crop Science, v.24, p.565-569, 1984.

ZEIDE, B. Tolerance and self-tolerance of trees. Forest Ecology and Management, v.13, p.149-166, 1985.

ZEIDE, B. Analysis of the 3/2 power law of self-thinning. Forest Science, v.33, p.517523, 1987. 